NBER WORKING PAPER SERIES

\title{
THE COSTS OF WRONGFUL-DISCHARGE LAWS
}

\author{
David H. Autor \\ John J. Donohue III \\ Stewart J. Schwab \\ Working Paper 9425 \\ http://www.nber.org/papers/w9425 \\ NATIONAL BUREAU OF ECONOMIC RESEARCH \\ 1050 Massachusetts Avenue \\ Cambridge, MA 02138 \\ December 2002
}

We are indebted to Joshua Angrist, David Card, Lawrence Katz, Alan Krueger, Thomas Miles, Andrew Morriss and seminar participants at the NBER Labor Studies Summer Institute, UC Berkeley, NYU Law School, Stanford Law School, and the American Law and Economics Association for excellent suggestions. We gratefully acknowledge the excellent research assistance of Rashida Adams, Michael Anderson, Simone Berkowitz, Sarah Bernett, Douglas Bosley, Craig Estes, Rose Francis, Scott Hemphill, Carolyn Heyman, Joshua Linn, Joshua Mayes, Marci Reichbach, and Leslie West, and the research coordination of Rose Merendino. The views expressed herein are those of the authors and not necessarily those of the National Bureau of Economic Research.

(C) 2002 by David H. Autor, John J. Donohue III, and Stewart J. Schwab. All rights reserved. Short sections of text not to exceed two paragraphs, may be quoted without explicit permission provided that full credit including, (C) notice, is given to the source. 
The Costs of Wrongful-Discharge Laws

David H. Autor, John J. Donohue III, and Stewart J. Schwab

NBER Working Paper No. 9425

December 2002

JEL No. E24, J23, J32, J38, J83, K12, K31

\begin{abstract}
We estimate the effects on employment and wages of wrongful-discharge protections in the United States. Over the last three decades, most U.S. state courts have adopted one or more common law wrongful discharge doctrines that limit employers' discretion to terminate workers atwill. Using this cross-state variation with a difference-in-difference framework, we find robust evidence of a modest negative impact ( -0.8 to -1.6 percentage points) of one wrongful-discharge doctrine, the implied-contract exception, on employment to population rates in state labor markets. The short-term impact is most pronounced for female, younger, and less-skilled workers, while the longer term costs appear to be borne by older and more-educated workers - those most likely to litigate under this doctrine. We find no robust employment or wage effects of two other widely recognized wrongful-discharge laws: the public -policy and good-faith exceptions. Published findings in the literature range from no effect to very large negative effects. We reanalyze the two leading studies and find the discrepancies can be explained by methodological shortcomings in the one case and limitations in the coding of key court decisions in the other.
\end{abstract}

$\begin{array}{lll}\text { David H. Autor } & \text { John J. Donohue III } & \text { Stewart J. Schwab } \\ \text { Department of Economics } & \text { School of Law } & \text { School of Law } \\ \text { MIT, E52-371 } & \text { Stanford University } & \text { Cornell University } \\ 50 \text { Memorial Drive } & \text { Stanford, CA 94305-8610 } & \text { Ithaca, NY 14583 } \\ \text { Cambridge, MA 02142-1347 } & \text { and NBER } & \\ \text { and NBER } & \text { jjd@stanford.edu } & \end{array}$

dautor@mit.edu 
What is the price of protection? This paper estimates the social costs, in terms of potentially lower employment and wages, of common law efforts to protect American workers from wrongfuldischarge. The cost of employment protection is a controversial issue. It is virtually received wisdom that the stagnant employment performance of many European economies during the 1980s and 1990s - 'Eurosclerosis' - can be attributed to the significant employment protection given European workers (cf., Lazear, 1991; Blanchard and Wolfers, 1999). According to this argument, employment protection is a double-edged sword. It provides employment security to incumbent workers but makes employers reluctant to hire, leading to a stagnant labor market with potentially lower employment and wage levels. Among the obstacles to testing this hypothesis is the difficulty in obtaining high quality data for cross-country comparisons.

In this paper, we study the impacts of employment protection in the U.S. setting. Several scholars have examined the effects of American federal employment laws on employment and unemployment. Acemoglu and Angrist (2001) and DeLeire (2000) present evidence that the Americans with Disabilities Act decreased employment of disabled persons. Oyer and Schaefer $(2000,2002)$ conclude that the federal Civil Rights Act of 1991 increased the frequency of mass layoffs and raised the returns to experience for workers who have a downward sloping 'age-litigation' profile. Hahn, Todd, and van der Klaauw (2001) also evaluate the costs of federal anti-discrimination laws. A major hurdle for each of these studies is that the federal statutes at issue apply all at once to the entire country. It is difficult to separate the effects of the statute from all other changes occurring at that time (cf., Donohue, 1998; Donohue and Heckman, 1991).

This paper overcomes some of these methodological challenges by evaluating employment protections that arise in various U.S. states at various times, thus providing greater variation with which to more accurately establish causal relationships. The United States, uniquely in the industrialized world, has long had a legal presumption that workers can be fired "at will" - that is, for any time and for any reason, good or bad. In the last two to three decades, however, most state courts have adopted one or more common law 'wrongful-discharge' protections that weaken the employment-at-will presumption. States vary greatly in the timing and extent of their recognition of these wrongful-discharge laws. Three states - Florida, Georgia, 
and Rhode Island - have never altered the employment at will doctrine. Ten states now recognize each of three broad classes of exception to the at-will doctrine : the Implied-contract, Public-policy, and Good-faith exceptions (their precise meaning is defined below). A few states have rejected prior adoptions (see Appendix Table 1). ${ }^{1}$ This variability in the extent and timing of states' recognition of wrongfuldischarge laws allows for empirical testing of their impacts on employment and wages.

We are not the first to explore these effects. In a widely cited line of research, Dertouzos and Karoly (1992 and 1993) used an instrumental variables framework to test whether wrongful-discharge laws affected state-level employment. They found surprisingly large impacts. Dertouzos and Karoly estimate that states adopting a tort-based cause of action (that is, one in which plaintiffs may sue employers for punitive damages) suffered a 3 percent reduction in aggregate state employment - roughly equivalent to a 10 percent employer side tax on wages - with an additional 1 or 2 percent employment decline for states also adopting a contract-based protection (that is, one in which plaintiffs may sue only for economic losses). ${ }^{2}$ These findings have not gone unchallenged. Morriss (1995) criticized Dertouzos and Karoly's legal variables. More recently, Thomas Miles (2000) used a differences-in-differences approach to estimate the impact of the wrongful-discharge doctrines. He reports "no statistically significant effects on either employment or unemployment," but does not comment on the source of the discrepancy between his findings and those of Dertouzos and Karoly. ${ }^{3}$

Our paper joins this debate at two points. First, we provide a comprehensive reevaluation of the impacts

\footnotetext{
${ }^{1}$ To date, only Montana (in 1987) has passed a statute establishing a good-cause standard for all employment terminations. All other employment at will exceptions are common law doctrines, i.e., case law. In 1991, the Uniform Law Commissioners proposed a Model Employment Termination Act similar to the Montana statute, but no state has yet adopted it. In 1996, the Arizona legis lature passed a statute affirming employment at will. Krueger (1991) provides a perceptive econometric study of the consideration of exceptions to the doctrine of employment at will by state legislatures.

${ }^{2}$ Dertouzos and Karoly (1988) earlier examined the direct costs of wrongful-discharge litigation in California. They found these direct costs to be modest, amounting to some $\$ 100$ per termination. See also Dertouzos and Karoly (1992; p. xi) (presenting findings of 1988 study).

${ }^{3}$ In related work, Kugler and Saint-Paul (forthcoming) find that a state's adoption of wrongful-discharge doctrines significantly slows the job-to-job flows of unemployed relative to employed workers. Autor (2003 forthcoming) and Miles (2000) find that employers increased demand for te mporary help agency employment when states adopted common law exceptions to employment at will.
} 
of wrongful-discharge doctrines on employment and wages using richer data and (we believe) a more complete coding of the case law than previous work. Second, we evaluate why the leading papers on this topic have reached opposing conclusions - ranging from no effect to very large negative effects - and provide a reconciliation of these findings.

As with the Miles and Dertouzos and Karoly studies, our key explanatory variables are the precedent setting cases that establish the wrongfuldischarge laws recognized in each state and time period. We differ from previous studies, however, by using legal and employment data observed at monthly intervals, by measuring wage as well as employment impacts, and by exploring these impacts separately by education and gender demographic subgroups over the near and longer term. We apply robust estimation techniques throughout and test the consistency and generality of our findings across specifications and time periods.

Although we had anticipated that our reanalysis would reconfirm the null hypothesis accepted by Thomas Miles, we instead find a modest but robustly negative impact of one wrongful-discharge doctrine the Implied-contract exception - on the employment to population rate in state labor markets. This impact, which averages -0.8 to -1.6 percent, is present for all education and gender groups, and is detectable among states adopting at several time intervals during the sample. The short term impact is most pronounced for females, and younger and less-educated workers. In the long term, however, the costs of implied-contract protection appear to be borne by older and more-educated workers - those most likely to litigate.

We also find some evidence that the Good-faith exception reduced state employment levels by a similar magnitude, but this evidence is far less robust. Finally, we find that both doctrines (Implied-contract and Good-faith) have a weakly positive association with wages - that is, observed wages of employed workers tend to rise by 0.5 to 1.5 percentage points after adoption of these doctrines. One interpretation of this finding is that employment protection strengthens worker bargaining power, leading to higher wages and lower employment levels (cf., Blanchard and Portugal, 2000). However, a more parsimonious explanation that we favor - and provide some evidence to support) - is that the negative employment impacts of the wrongful-discharge laws are borne by the lowest-wage workers within given demographic groups, leading to an upward composition bias in observed wages. 
To reconcile the substantial discrepancies between our findings and the prior literature, we reanalyze the work of Dertouzos and Karoly (1992) and Miles (2000). We find that the exceedingly large disemployment effects estimated by Dertouzos and Karoly - three to five times the magnitude of our estimates - appear driven by problematic instrumental variables that are spuriously correlated with regional employment trends that substantially predate states' adoption of wrongful-discharge laws. By contrast, the differences between our findings and those of the methodologically similar Miles's study are primarily explained by discrepancies in the coding of key court cases. By making warranted modifications to these analyses, we demonstrate that these prior results may be reconciled with our own.

\section{Wrongful-discharge laws}

\section{A. Common law exceptions to employment at will: Definition and legal significance}

Since the heyday of employment at will in the early part of the $20^{\text {th }}$ century, legislatures and courts have restricted employers' discretion to terminate workers at-will in several ways. Broad federal statutes prohibit employers from firing workers on the basis of union activity, race, color, religion, sex, national origin, age, or disability. ${ }^{4}$ Specific federal and state statutes prevent employers from terminating workers for a variety of precisely defined impermissible reasons, such as to avoid pension benefits from accruing, or to retaliate because a worker reported occupational safety and health violations or served as a juror. ${ }^{5}$

In addition to these statutory restrictions, state courts have over the last 30 years substantially modified the employment at-will doctrine. These modifications, which we refer to as wrongful-discharge laws, are commonly classified in three categories: (1) the tort of wrongful-discharge in violation of public-policy ('Public-policy exception'); (2) the implied-in-fact contract not to terminate without good cause ('Impliedcontract exception'); and (3) the implied covenant to terminate only in good-faith and fair dealing ('Good-

\footnotetext{
${ }^{4}$ National Labor Relations Act § 8(a)(3), 29 U.S.C. §158(a)(3) (enacted 1935) (prohibiting discrimination on the basis of union status); Title VII of the Civil Rights Act of 1964, 42 U.S.C. $\S \S 2000$ e to 2000e-17 (prohibiting discrimination on the basis of race, color, sex, religion, or national origin); Age Discrimination in Employment Act of 1967, 29 U.S.C. §§ 621-634; Americans with Disabilities Act of 1990, 42 U.S.C. §§ 12101 - 12213.

${ }^{5}$ Employee Retirement Income Security Act of 1974 § 510, 29 U.S.C. § 1140 (prohibiting discrimination against employees because they might obtain benefits in a pension or welfare plan); Occupational Safety and Health Act of $1970 \S 11,29$ U.S.C. 660(c) (prohibiting discrimination against employees exercising rights under OSHA); New York Judiciary Law $§ 519$ (prohibiting discharge of employee due to absence from employment for jury service).
} 
faith exception'). We define these in turn and discuss their significance.

As of 1999, all but seven states recognized the tort of wrongfuldischarge in violation of public-policy. Classic violations of this 'retaliatory discharge' doctrine include firing a worker for refusing to perform an illegal act, such as perjuring himself on behalf of the company; for exercising a statutory right, such as filing a workers' compensation claim; or for performing a public obligation, such as serving on a jury. As Schwab (1996) discusses, courts tend to apply this exception to the at-will doctrine when the termination clearly affects third parties, thereby justifying the judicial interference with the at-will employment contract. Successful plaintiffs can recover compensatory damages for lost earnings, as well as damages for pain and suffering, and punitive damages in appropriate cases.

Because the public-policy exception is widely recognized (43 states) and provides for full compensatory and punitive damages, it is sometimes viewed as the most significant exception to the at-will doctrine. In point of fact, however, successful public-policy cases - particularly those with multi-milliondollar judgments - are rare, albeit highly public ized. The reason for their rarity is that courts have typically limited the scope of public-policy cases to clear violations of express legislative commands (e.g., the duty to perform jury service, the right to file a workers' compensation claim) rather than violations of a vaguer sense of public interest. Some legal scholars have argued accordingly that the attention given this doctrine in the popular and business press exceeds its legal and economic significance (see Edelman et al 1992).

Only 11 states now recognize a second doctrine, the covenant of good-faith and fair dealing. ${ }^{6}$ A classic illustration of this exception is the case of Fortune v. National Cash Register Co. in which the employer fired a salesperson who had completed a substantial sale just before his commission was due. The court ruled that the employer had deprived the plaintiff of the "benefit of his bargain" in bad faith. ${ }^{7}$ Like the public-policy exception, the good-faith doctrine could have sweeping employer consequences. In its broadest form, this exception can be read as a general prohibition against terminating any worker for any reason other than 'just cause' - that is, economic necessity or poor performance. Most courts, however,

\footnotetext{
${ }^{6}$ Oklahoma and New Hampshire recognized good-faith as a distinct action in the past.
} 
have limited application of the good-faith exception to grossly unfair 'timing' cases such as Fortune, where the termination deprives the worker of a specific promised benefit such as a sales commission or an imminently-vesting pension. ${ }^{8}$ Hence, the onus of this doctrine is probably somewhat less than was originally anticipated by employers and legal scholars.

Finally, 43 states recognize a third exception to employment at will, the implied-contract doctrine. This exception arises when, through words or actions, an employer implicitly promises not to terminate a worker without good cause. A landmark decision establishing this exception was the 1980 case of Toussaint v. Blue Cross \& Blue Shield, in which the Michigan Supreme Court held that an employer's indirect statements about the manner in which it made termination decisions can create legally binding employment contracts. ${ }^{9}$ In Toussaint, the plaintiff successfully sued for breach of contract by citing an internal personnel policy handbook indicating that it was Blue Cross's policy to terminate employees only for just cause. Although Toussaint was unaware of the handbook when hired, the court held that the handbook implied a binding contract. Courts in 23 other states issued similar decisions over the next 5 years.

An equally influential 1981 California case, Pugh v. See's Candies, further expanded the impliedcontract notion by finding that workers are entitled to ongoing employment even in the absence of written statements if contractual rights are implied in fact through the context of the employment relationship. ${ }^{10}$ This context may include longevity of service, a history of promotion or salary increases, general company policies as exemplified by treatment of other employees, or typical industry practices. Cumulatively, these court decisions generated substantia 1 uncertainty surrounding termination, resulting in numerous cases

\footnotetext{
${ }^{7} 364$ N.E.2d 1251 (Mass. 1977).

${ }^{8}$ While Fortune did not reach the issue, some state courts allow tort damages (including punitive) for breaches of the good-faith covenant in employment contracts. During our period of study, California recognized a broader set of goodfaith obligations that is hard to distinguish from a general obligation not to fire without good cause. The leading California case is Foley v. Interactive Data Corp., 765 P.2d 373 (Cal. 1988), in which a bank employee was fired for reporting to upper management that the FBI was investigating his immediate supervisor for embezzlement from a prior employer. The court declared these facts could amount to a breach of the covenant of good-faith and fair dealing, but held that only contract damages, not full tort damages, were recoverable. In Guz v. Bechtel National, Inc., 8 P.3d 1089 (Cal. 2000), after our period of study, the court restricted good-faith claims to those like the Fortune case.

${ }^{9} 292$ N.W.2d. 880 (Mich. 1980).

${ }^{10} 171$ Cal. Rptr. 917 (Cal. Ct. App. 1981).
} 
where courts found that employees held implied-contractual employment rights that employers had not subjectively intended to offer.

The employer costs of the implied-contract exception are difficult to assess, however. Since impliedcontract cases lead only to contractual damages (e.g., punitive damages are excluded), the threat of a spectacular jury award is low. In addition, an employer can potentially insulate itself from implied-contract claims by rewriting employment contracts and handbooks to clearly state that all employment contracts are at will. ${ }^{11}$ However, unlike the public-policy and good-faith doctrines, which penalize individual instances of unethical employer behavior, the implie d-contract doctrine can pervasively affect an employer's personnel practices. By imbuing employer handbooks with the status of legal contracts, the implied-contract doctrine has the potential to reclassify an employer's entire workforce as not at will, causing the employer to alter how it handles all hiring and firing decisions.

Unfortunately, no comprehensive data exist on the number or outcome of wrongfuldischarge cases under these three doctrines. ${ }^{12}$ Two findings in the literature suggest, however, that the implied-contract exception may have altered employers' hiring practices (leaving aside temporarily the Dertouzos and Karoly analysis, to which we return below). First, Miles (2000) and Autor (2003) find that employers substantially increased their use of temporary help agency workers shortly after their states adopted implied-contract exceptions. Second, Kugler and Saint Paul (forthcoming) find that the hiring odds of unemployed workers declined after courts in their states recognized the implied-contract exception. Though neither of these results speaks to the core of our analysis - the impact of these doctrines on employment and wages levels - they do indicate that employers were aware of the implied-contract exception (at a minimum) and took steps to mitigate litigation risks. ${ }^{13}$

\footnotetext{
${ }^{11}$ It remains a complex legal question, however, whether an employer that once issued a handbook or other promise of job security can modify it to create at-will employment. Several courts have held that such unilateral changes by the employer are not binding on incumbent employees that have previously received promises of job security.

${ }^{12}$ Nor would this caseload data provide a complete measure of the economic costs of wrongful-discharge laws since the observed caseload is an equilibrium function of employer decisions to avert or settle suits (supply) and employee incentives to file suits (demand).

${ }^{13}$ We attempted to test whether adoption of a wrongful-discharge exception by a state increased the number of law firms listing employment law as a specialty using firm-practice data from the Martindale-Hubbell listings of lawyers.
} 


\section{B. Hypothesized effects on the labor market}

As discussed by Lazear (1991) and Blanchard and Katz (1997), the theoretical impact of firing restrictions on employment levels is ambiguous. In a frictionless labor market with costless courts, the Coase theorem applies. Imposition of employer-side firing costs are fully undone by efficient worker-firm bargains, such as the posting by workers of a bond equal to firing costs. Where the Coasean result does not hold, firing restrictions reduce employers' incentives both to hire new workers and fire incumbent workers (Donohue, 1989). Accordingly, firing restrictions dampen employment fluctuations, which may raise or lower employment levels in the short term. Over the longer term, if employment protection raises employment costs without yielding corresponding productivity increases, employment levels and/or wages are likely to fall. This is particularly true if wrongfuldischarge laws encourage rent-seeking behavior by employees or induce employers to retain unproductive workers due to fear of litigation.

Not all (non-Coasean) employment protection adversely impacts labor market efficiency, however. Employment protection can be usefully viewed as a mandated employment benefit that, while costly for employers to provide, is also valued by employees (Summers, 1989). By raising employer costs, mandated employment protection shifts labor demand inward. But to the degree that workers value the mandated benefit, labor supply simultaneously shifts outward, muting the adverse employment impact. If employees value the benefit at its full marginal cost, wages will in theory fall to cover the cost of providing the benefit and employment levels will be unaffected (see, for example, Gruber, 1994). ${ }^{14}$

While the overall impact of erosions of the at-will doctrine on employment or unemployment is not clear a priori, existing evidence suggests that the impact may differ for different groups of workers. Several

Because much of these data had to be hand-coded, we were only able to obtain data on three years $(1979,1985$, and 1992-93). We found that the adoption of the good-faith exception by California and Montana, generally regarded as the two states most aggressively eroding employment at will during this period, significantly increased the share of employment specialties in those states relative to both all practices and to tax specialities. Perhaps because of the crudity of the measures and the few years, we were unable to detect consistent patterns in other states or for the tort or implied-contract exceptions. Details and tables are available from the authors upon request.

${ }^{14}$ Moreover, as several authors have argued, the presence of adverse selection in the labor market may cause employers to provide inefficiently low levels of job security (Aghion and Hermalin, 1990; Levine, 1991). Imposition of firing restrictions could therefore raise employment while reducing wages. This would correspond to a case where workers value job security more at the margin than it costs employers to provide. 
authors find that the employment of younger, less-educated workers appears most likely to be harmed by wrongful-discharge protections, while older and more-educated workers appear to benefit (OECD, 1999, Chapter 2; Jolls, 2000; Bertola, Blau and Kahn, 2002). We examine these disparate impacts in depth below and find important differences by demographic group which depend on the time horizon examined.

\section{Data sources and model specification}

\section{A. Data sources}

To measure employment and earnings, we draw on the complete CPS monthly files for the years 1978 to 1999 . These files provide individual labor-force data for approximately 100,000 adults per survey month and also contain wage data for one-quarter of the employed sub-sample beginning in $1979 .{ }^{15}$ We calculate the employment to population ratio (or its $\log$ ) and median log hourly or full-time weekly wages of currently employed workers for eight demographic groups in each state and time period: two genders, two education groups (high school or less, some college or more), and two age groups $(18-39,40-64){ }^{16}$

To maximize usable variation in the timing of the adoption of wrongful-discharge laws, we code the legal and employment variables at monthly frequency, as was done by Morriss (1995). Hence, if two states adopt a wrongful-discharge doctrine 11 months apart within the same calendar year, our estimates accurately account for this substantial difference in timing. Because the outcome data are observed at high frequency, serial correlation is a major concern. Following the recommendations of Bertrand, Duflo and Mullainathan (2002), we apply Huber-White robust standard errors clustered by state throughout. ${ }^{17}$ These allow for arbitrary error correlations among observations within states, both over time and among demographic groups.

For our legal variables, we developed a taxonomy of wrongful-discharge law prevailing in each state

\footnotetext{
${ }^{15}$ Individuals may appear up to four times in one calendar year in the employment sample (not the wage sample), though their labor force status may differ on each occasion. Our estimation procedure takes account of potential serial correlation among observations within each state sample.

${ }^{16}$ Because the wage sample is less than one quarter the size of the employment sample, we use median wages to reduce the influence of outliers. Results using mean wages instead are, however, quite similar.

${ }^{17}$ Except in Table 4, in which we provide disaggregated estimates by adopter cohorts, in which case there are relatively few state clusters. Here, we cluster the standard errors by state for contiguous time periods but assume independence across non-contiguous periods (always at least 13 months apart).
} 
and month-year for the two-decade period from 1978 to 1999. As Morriss (1995) discusses, it is not always easy to date when a state has adopted a particular at-will exception. Our objective is easily stated, however. We envision management-side employment lawyers reading the advance sheets and writing awareness letters to their clients when major changes occur in the common law. Thus, we are interested in the first court decision in a state that would trigger a client letter warning about a law change. In practice, our independent assessment of the legal doctrines in this area for the 50 states largely agrees with Morriss's list of relevant cases, although we had to update the list through the 1990 s. $^{18}$ In Section V, we test the sensitivity of our conclusions by employing classifications developed by Dertouzos and Karoly (1992), Morriss (1995), and Walsh and Schwarz (1996) - the last used by Miles (2000).

\section{B. Model specification}

Because the common-law wrongful-discharge doctrines were adopted in different months and years by most U.S. states during the 1980s and 1990s, we have potentially many 'experiments' to exploit. Our empirical approach is to contrast the change in employment and wages of demographic subgroups within states adopting a given wrongful-discharge doctrine in a given period to states not adopting any doctrine during the same time period.

To implement this difference-in-difference design, we need to select a 'before' and 'after' period for pre-post comparisons. Although we could use the entire 1978 - 1999 panel to calculate these contrasts for each state, this approach has two disadvantages. First, because states adopted exceptions as early as 1979 and as late as 1998, the long panel approach implies that for some states, observations from 19 years before or after adoption would be used to form a pre/post contrast. This is unappealing. Second, the long panel approach exacerbates the serial correlation issue noted above. To mitigate these issues, we primarily use a five-year pre-post window. The 24 calendar months prior to adoption of a doctrine are designated as the pre-period; months 13 to 36 following adoption are designated as the post-period; and the first 12 months immediately following adoption are excluded from the sample, to allow for an adjustment interval. We

\footnotetext{
${ }^{18}$ Although we use the three-part division of the at-will exceptions in the body of our analysis, we explored the relevance of the tort/contract distinction on which Dertouzas and Karoly focus. We did not find this distinction to be
} 
explore the sensitivity of our results to this set of choices below.

To form a control sample of non-adopting states, we include the maximal set of state-month observations for corresponding calendar months (rounded to the nearest calendar year) for states that did not adopt any of the three doctrines during the relevant pre/post treatment time interval. Note that this design implies some states serve as treatment states in one period and control states in another, although never within a five-year window surrounding treatment.

The basic econometric model that we estimate is

$$
Y_{s t}=\alpha+\beta_{1} L_{s}+\beta_{2} \text { Post }_{s t}+\gamma \cdot \text { Post }_{s t} \cdot L_{s}+\varepsilon_{s t}
$$

where $Y_{s t}$ is employment or earnings for a demographic group in state $s$ and time period $t, L_{s}$ is a timeinvariant dummy variable equal to one if a state will adopt a given exception during the pre/post sample interval and Post $t_{s t}$ is a dummy variable equal to one in months 13 to 36 following adoption. The coefficient of interest, $\gamma$, is an estimate of the pre-post change in the outcome variable in adopting states relative to the corresponding change in non-adopting states. All estimates are weighted by the sum of sample weights in the state-year-month-demographic cell, reflecting the estimated count of U.S. residents or employed persons in the cell for employment and earnings respectively.

We enrich this basic model in three ways. First, in place of the common main effect and pre-treatment indicators ( $\alpha$ and $L_{s}$ ), we add main effects for each state and their interactions with a treatment indicator variable. ${ }^{19}$ Second, to non-parametrically account for common national shocks to employment overall and by demographic group, we also include dummy variables for each monthly calendar time period interacted with indicator variables for each of the eight demographic groups in the sample. ${ }^{20}$ Finally, to account for common regional shocks to employment, we also estimate models that include interactions between calendar-year dummies and indicator variables denoting the nine Census geographic regions. With these

relevant or empirically robust. Supplemental tables are available from the authors on request.

${ }^{19}$ If a state serves in both the control and treatment groups in a given model, we also include a state $\mathrm{x}$ treatment dummy equal to one in the 24 months immediately preceding treatment.

${ }^{20}$ In the full sample, this corresponds to 8 groups $\mathrm{x} 22$ years $\mathrm{x} 12$ months $=2,122$ dummy variables. 
region controls included, the parameter $\gamma$ is identified only by the contemporaneous contrast in employment or wage outcomes in adopting versus non-adopting states located in the same geographic regions.

\section{Impacts on employment and earnings}

Before estimating equation (1), we provide a visual summary of the data in Figures 1 through 6 . These depict estimated log employment to population rates (Figures $1-3$ ) and log median wage levels (Figures 4 - 6) in adopting relative to non-adopting states at monthly intervals in the 48 months prior through 96 months following adoption of each doctrine. Wage and employment levels in the first full month following adoption are normalized at zero. ${ }^{21}$ The dashed lines in each figure represent robust 90 percent confidence intervals for each monthly point estimate.

These figures provide initial evidence that one wrongfuldischarge doctrine, the implied-contract exception, did indeed affect state employment levels. As is visible in Figure 1, relative (log) employment to population rates for both males and females dip by approximately 1.5 to 2 percent over the 2 years following adoption of the implied-contract exception, reaching a nadir after approximately 30 months. By contrast, Figures 2 and 3 provide little evidence that the public-policy or good-faith exceptions affected employment. One cannot make strong inferences from these figures, however. As is visible from the wide standard-error bands, the monthly point estimates are relatively noisy. In addition, these models do not include the full set of controls that we (later) use for estimating equation (1). Nevertheless, the formal analysis of employment below largely bears out the impression given by the figures.

Figures 4 through 6 repeat this exercise for median log weekly earnings of full-time workers. Because

\footnotetext{
21 These figures plot the coefficient and 90 percent confidence bands from estimates of parameters $\gamma_{\tau}$ from the following equation:

$Y_{s t j}=\delta_{s}+\phi_{t}+\pi_{j}+\sum_{\tau=-48}^{96} \gamma_{\tau} \cdot L_{s, t-\tau}+\varepsilon_{s t j}$,

where, as above, $Y_{s t j}$, is the outcome variable for a given demographic group, state, and time period, $\delta_{s}, \phi_{t}$ and $\pi_{j}$ are vectors of state, time, and demographic group main effects, and $L_{s t}$ is a dummy variable that assumes the value of one (only) in the month that a state adopts a given doctrine (the impact of each doctrine is estimated simultaneously). Huber-White standard errors allow for arbitrary error correlations within states.
} 
the samples used for these estimates are less than one-fourth as large as the employment estimates, there is a great deal more variability in these observations. These figures provide little prima facie evidence that wrongful-discharge doctrines affected wage levels of employed workers.

\section{A. Initial estimates: Employment and Wages}

Table 1 presents estimates of equation (1) for employment and wages. What emerges clearly from the estimates in this table is that adoption of the implied-contract exception is associated with a modest but meaningful reduction in employment. In column 1 of Panel A, we estimate that adoption of the impliedcontract doctrine reduces overall employment to population by 2.0 percent in the second and third years following adoption $(\mathrm{t}=4.1)$. When controls are added to the model to absorb region-by-year employment shocks (column 2), the point estimate and its standard error are both reduced by approximately half, indicating that the implied-contract doctrine was typically adopted when employment conditions were at slightly above-average levels (a fact also suggested in Figure 1). The employment impact is estimated at 1.0 percentage points, which is highly significant $(t=3.2)$.

The next two rows of the table repeat these estimates for the public-policy and good-faith doctrines. The public-policy doctrine is associated with a small reduction in employment, but these reductions are never significant. The point estimates for the good-faith doctrine are of approximately equal magnitude to those for the implied-contract association. These coefficients are marginally significant and are not typically robust to inclusion of region-by-year controls. Since there are fewer good-faith adoptions than for other doctrines (13 for good-faith versus 43 and 34 for implied-contract and public-policy), there may be inadequate statistical power to reliably detect its impacts.

As one specification check, columns 3 and 4 of Table 1 replace the log employment-to-population ratio measure with its level. The outcome variable is now the percentage point change in employment to population rather than its percentage change. Under this specific ation, the implied reductions in 
employment to population are very slightly smaller, while statistical significance is unaffected. ${ }^{22}$

Panel B of Table 1 presents comparable estimates for both median log hourly and full-time weekly wages. In no case are the point estimates statistically significant. However, a notable pattern is that doctrines that appear to reduce employment (implied-contract and, to a lesser degree, good-faith) are associated with a modest increase in median wages of employed workers. One explanation for this pattern is that workers whose employment is reduced by adoption of a wrongful-discharge law are typically below the median earners in their state-demographic cell. Hence, their removal from the observed earnings sample raises the median wage slightly. We provide further evidence on the relevance of this explanation below.

\section{B. Does the specific doctrine matter?}

Given the generally negative estimated employment impact of each category of doctrine, one potential interpretation of these results is that it is not the specific doctrine that matters but simply the fact that any wrongful-discharge doctrine has been adopted. To examine this issue, we estimate in Table 2 a set of models that compare the impacts of an 'any doctrine' variable against a disaggregated set of three doctrine variables. As with the previous models, we specify the two-year period prior to law change as the pretreatment period and the two-year period commencing one year after law change as the post-treatment period. $^{23}$

The first two columns of Table 2 confirm that, on average, adopting any doctrine appears to lower employment by between 0.5 and 1.0 percent, with the smaller point estimate corresponding to the model in which region by time effects are controlled. In addition to the any-doctrine dummy, Columns 3 and 4 add

\footnotetext{
${ }^{22}$ We also estimated Table 1 without using the CPS sampling weights, which yielded comparable results, as shown in Appendix Table 2. By comparison with the weighted estimates, this table shows: 1) the point estimates for the Implied-contract exception are about $2 / 3$ rds as large in absolute magnitude for employment and still highly significant; 2) the Public-policy and Good-faith exceptions are also negative and marginally but not robustly significant; 3 ) the wage estimates are simi lar; and 4) the R-squareds are lower, consistent with the inefficiency of the weighting (or lack thereof).

${ }^{23}$ An additional wrinkle in this specification is that several states adopt multiple doctrines within a five year window and hence the pre- and post- periods are not unique. In estimating these models, we include all relevant pre- and posttreatment observations for a given state - meaning that some treatment and control periods overlap - and include, as in equation (1), treatment and treatment $\mathrm{x}$ post effects for each doctrine. Control observations are selected identically to Table 1 models.
} 
an indicator variable for each of the three doctrines. Notably, the any-doctrine dummy is positive in these specifications while each of the three individual doctrine dummies is negative and, in most cases, significant. This suggests that it is not simply the presence of any doctrine that reduces employment levels; the specific doctrine does matter.

Because the net effect of a doctrine in columns 3 and 4 is the sum of its individual dummy and the anydoctrine dummy, it is useful to eliminate the any-doctrine dummy to get a clearer picture. This is done in columns 5 and 6 . When the impact of all doctrines is estimated jointly, the implied-contract doctrine remains robustly negative and similar in magnitude to the Table 1 estimates. The good-faith doctrine again proves non-robust to inclusion of region-by-year controls.

Panel B of the table performs the same exercise for wage outcomes. As above, the any-doctrine dummy does not survive inclusion of individual doctrine controls. The data again provide modest evidence of a positive wage impact of the implied-contract and, more sizably, the good-faith doctrine.

\section{Checking for composition bias in the wage estimates}

Estimates of the impact of wrongful-discharge laws on wages may suffer from composition bias: since wages are only observed for currently employed workers, wrongfuldischarge laws will raise observed wages if they differentially reduce employment of low-wage workers. One means to test the relevance of this explanation is to adjust wage observations for selective withdrawal. We do this following Chandra (2002) by estimating median wages within state-year-month-demographic cells across all potential workers - employed and non-employed - and assigning a wage of zero to non-employed. This 'inclusive median' approach stands in contrast to the standard 'exclusive median' calculations used above, which removed non-employed from the samples. Because the inclusive median implicitly assumes that non-employed workers would earn below the median wage in their respective state-time-demographic group cell, it places the estimated median lower in the distribution of cell wages. One shortcoming with this approach is that if 50-plus percent of potential workers in a cell are non-employed, the median cell wage will be zero and hence the cell must be discarded, which excludes most female cells as well as cells with high participation variability. Consequently, we limit our analysis in this section to males and, for comparability, apply the 
same cell exclusions to both the exclusive and inclusive medians.

Panel A of Table 3 presents difference-in-difference wage estimates for conventional exclusive hourly wage medians akin to Tables 1 and 2. These estimates echo the earlier finding that observed wages rise significantly after adoption of a wrongful-discharge doctrine, particularly the implied-contract exception (see column 6). Panel B presents comparable models for the inclusive medians. These estimates effectively reverse the positive wage finding. In many cases, the point estimates for the impact of adoption of a wrongful-discharge law on wages are now negative. In no case are the estimates significantly positive.

This set of results suggests that employment declines associated with adoption of a wrongful-discharge law could potentially generate significant upward composition bias in observed wages. Given the sensitivity of the wage estimates to composition bias, we focus the remainder of the analysis on employment.

\section{Cohort effects in adoption?}

The preceding estimates pool all years of data to increase the precision of the estimates. The cost of this approach is that it masks any temporal heterogeneity in the economic impact of the doctrines. Table 4 studies this potential heterogeneity by tabulating the effect of each exception on employment and earnings for the following adoption 'cohorts': 1980 to 1983,1984 to 1987,1988 to 1992 , and 1993 to $1998 .^{24}$

The 15 states that adopted the implied-contract exception during 1980 to 1983 experienced a decline of -0.5 to -1.9 percent in employment during months 13 through 36 following adoption (the smaller estimate corresponding to the model with region by year controls). The 18 states that adopted this exception between 1984 and 1987 also experienced similarly large employment declines. By contrast, we do not find robust evidence that the final set of 10 states that adopted the doctrine between 1988 and 1992 experienced any negative effect on employment, although the direction is generally negative.

The next four columns of Table 4 repeat these estimates for states adopting the public-policy and goodfaith exceptions. These estimates give rise to widely varying signs and magnitudes for each doctrine and

\footnotetext{
${ }^{24}$ Adoption cohort dates refer to the year a wrongful-discharge doctrine is enacted; the pre- and post-periods used to form the employment contrast are as with prior estimates the surrounding five years ( 2 prior to adoption, 3 post adoption, with the first omitted). We do not study adoptions prior to 1980 to allow for the two year pre-treatment period. No implied-contract or public-policy exceptions were adopted after 1992.
} 
time period, and are quite sensitive to the inclusion of region by year controls. This set of findings reduces our confidence that the good-faith exception adversely affected employment levels, except perhaps for the initial cohort of adopting states in the early 1980s.

An interesting pattern that emerge s from Table 4 is that the implied-contract and good-faith doctrines appear to have had smaller (or zero) employment impacts among later adopting states. One explanation for this pattern is that early adopting states may have been those that were most aggressive in their pursuit of employee rights and thus experienced greater negative effects on employment. Another explanation is that employers in later adopting states anticipated the eventual adoption of the doctrines and hence largely responded in advance, thereby causing the regression estimates for the late adoptions to understate the total effect. A third possibility is that the state level impact of the law differs when few states have previously adopted the exception than when most states have already done so. Employment declines found for early adopters may partly reflect decisions by employers to locate in other states, a possibility that is largely foreclosed when most states have already adopted an exception. The diminishing effects also suggest a fourth explanation offered by Edelman, Abraham and Erlanger (1992). These authors argue that professional (non-academic) law journals and personnel journals overstated the threat posed by the impliedcontract doctrine, leading to excessive management changes. Benefiting from the experience of these early adopters, employers in later adopting states might have reacted less severely to adoption of wrongful discharge doctrines. ${ }^{25}$

\section{E. Longer term impacts and alternative timing assumptions}

In our baseline specification, we use the 24 months prior to adoption as our pre-treatment period and the months 13 to 36 following adoption as the post-treatment period. In Table 5, we measure longer term impacts of the wrongfuldischarge doctrines and additionally explore the sensitivity of our findings to alternative choices of pre- and post periods.

\footnotetext{
${ }^{25}$ For example, Business Week in July 1985 ran a rather alarming cover article on "The Revolution in Employee Rights" that stated, "To minimize liability, corporations have to treat each dismissal as though it were under a "just cause' provision of a contract" (Hoerr et al, 1985).
} 
The first column of Table 5 repeats our baseline specification for employment from Table 1. Columns 2 through 6 of the table move the post-adoption treatment window closer to the point of adoption by 1 year (i.e., immediately thereafter) and then outward by 1, 2, 4, and 6 years respectively. In the final column, column 6 , the post-treatment period is years 7 and 8 following adoption. These estimates indicate that the employment effect of the implied-contract doctrine reaches a maximum in the two years following adoption, and this impact appears to gradually diminish thereafter. By years 7 and 8, the estimated employment reduction is considerably smaller than the baseline and is insignificant (a pattern also suggested by Figure 1). By contrast, the estimated negative effect of the good-faith doctrine increases with time, but this effect is never significant.

To test the sensitivity of the results to the selection of the pre-treatment period, columns 7 and 8 of the table adjust the pre-treatment interval outward by 1 and 2 years respectively (using the baseline posttreatment period of years 1 and 2 following adoption). Column 7 compares employment in years 2 and 3 prior to adoption to employment in years 1 and 2 following adoption, and column 8 performs this comparison for years 4 and 3 prior to adoption. Changing the pre-treatment window does not greatly affect the pattern of results but does reduce the precision of the estimates. When region by year dummies are included, the implied-contract doctrine no longer has a significant employment effect.

\section{Are all workers equally affected?}

Like their European counterparts, U.S. wrongful-discharge laws disproportionately protect workers with longer tenure and higher wages. Long-tenure workers are typically able to make a prima facie case that their jobs provided an expectation of ongoing employment (in the case of the implied-contract doctrine), or an expectation of future benefits for current service (good-faith doctrine). In addition, court awards tend to be roughly proportional to prior earnings - particularly in implied-contract cases - and hence high wage workers have a greater incentive to litigate. ${ }^{26}$ Since the protections offered by wrongful-discharge doctrines

\footnotetext{
${ }^{26}$ This is particularly true because attorneys' fees are usually arranged on a contingency basis; the attorney receives a percentage of the award if the case is successful and typically no payment otherwise. Consistent with these facts, Dertouzos, Holland and Ebener (1988) find that plaintiffs in wrongful-discharge cases are typically male (69 percent),
} 
are not equally distributed among worker groups, it is useful to ask whether the employment impacts also differ among demographic subgroups.

We explore this possibility in Table 6 by examining the relationship between the adoption of wrongfuldischarge laws and the employment rate of each of the 8 demographic groups that were pooled in the above analysis. Consistent with the above, the results in Table 6 confirm that the implied-contract doctrine lowers employment rates across the board. But the size of the impact differs substantially by demographic group. The largest impacts are uniformly found for female, less-educated (high school or less), and younger (under age 40) workers. These impacts are in the range of -1.0 to -2.7 percentage points. Young, less-educated females fare worst of all. Notably, the one demographic group for whom there is no evidence of an employment impact (for either gender) is older, more-educated workers. We also find modestly robust evidence (large point estimates, large standard errors) of a negative impact of the good-faith exception on employment rates. But this impact is only detected for women and younger, less-educated men.

As a group, the Table 6 results appear consistent with a number of OECD studies that find that employment protections tend to differentially harm employment of females, less-experienced workers and less-skilled workers (Bertola, Blau and Khan, 2002; OECD, 1999). Yet, in the U.S. context, these results appear something of a puzzle. U.S. wrongful-discharge doctrines increase the expected cost of employing high-tenure, high-wage workers. These higher costs should lower the employment and earnings of these groups and raise demand for workers who are close substitutes - low-wage and short-tenure employees who are unlikely to (successfully) litigate. ${ }^{27}$ Yet, this is opposite to what we find. Why do wrongful discharge laws harm the employment rates of less protected workers?

Two rationales are found in the literature. One is that less protected groups - females, less-educated, and younger workers - have greater opportunity costs of work (i.e., better opportunities in home production, school enrollment, and leisure) and accordingly their labor supply is relatively elastic. If employment

\footnotetext{
hold executive or managerial positions (53 percent), have 6 or more years of tenure (48 percent), and earn considerably above the median wage.

${ }^{27}$ This may indeed be what occurred with the surge in demand for temporary help employment after adoption of implied-contract exceptions in various states (Autor, 2003).
} 
protection is chosen to maximize worker welfare, it will optimally price many of these workers out of the labor market, raising their wages and reducing their employment (Bertola, Blau and Khan, 2002). An alternative explanation offered by Lindbeck and Snower (1988) and Saint Paul (2002) is that employment protection is typically adopted to protect incumbent ('insider') workers who, on average, are likely to be older, more-skilled males. These protections reduce productivity and generate rents for incumbents, while weakening earnings and employment prospects for younger, less-skilled, and less attached labor force participants ('outsiders'). Both theories therefore offer a rationale for why women, younger and less-skilled workers are harmed by employment protection. Do they fit the U.S. facts?

In case of the first theory, the intervening mechanism by which employment protection lowers employment of 'more elastic' workers is by raising their relative wages. This prediction does not seem to fit the U.S. case. In particular, it is unclear how U.S. wrongful-discharge laws could disproportionately raise employment costs for the 'elastic' groups since these workers are provided relatively less employment protection. And while our data offer some weak evidence that the wages of elastic groups do increase after adoption of wrongfuldischarge doctrines, we view this evidence as primarily driven by selection of lowwage workers into non-employment. Hence, in our view, the first explanation does not appear viable.

The second, 'insider-outsider' explanation is more promising. If wrongful-discharge laws successfully deter employers from terminating higher wage and longer tenure workers ('insiders') and further employers are not able to reduce the wages of protected groups in the short run, employers will presumably need to reduce hiring of some worker groups to maintain employment levels. In this case, wrongful-discharge laws will protect the jobs of more senior workers but the cost will be borne by younger workers who are not hired in their place. This is roughly the mechanism posited by the insider/outsider models. ${ }^{28}$

Over the longer term, however, employers should prefer to reduce employment of senior workers relative to less expensive alternatives. Although this longer run outcome is presumably difficult to measure

\footnotetext{
${ }^{28}$ More generally, if adoption of wrongful-discharge laws induces any general employer reluctance to hire new workers, this impact will first be visible in a decline in the employment rates of high turnover worker groups females, and younger and less-educated workers. Noting that younger and less-educated workers also comprise a
} 
in aggregate data, we make a preliminary effort in Table 7. Here, we estimate long-run difference-indifference models for state level employment by demographic group where we contrast the change in employment in adopting versus non-adopting states in years five and six following law adoption relative to years two and one prior to adoption. ${ }^{29}$ As would be expected, the point estimates in this table are not precisely estimated. Nevertheless, a noteworthy pattern is that the estimated long-run negative effects of the implied-contract doctrine on the employment of older and more-educated workers are generally larger than those for younger, less-educated worker (and in many cases, larger than the short-run estimates from Table 6). Similarly, the long-run estimates for younger and less-educated workers are generally substantially smaller than the short run estimates, and in some cases weakly positive. ${ }^{30}$

In net, our estimates confirm patterns from the OECD that employment protection does reduce employment of less protected worker groups - females, and younger and less-educated individuals - at least in the short run. While less decisive, our longer term evidence suggests that the harms in terms of reduced employment tend to accrue to the workers whose expected employment costs are raised by these doctrines. This result may suggest an important difference between employment protections provided in the OECD and United States. Whereas OECD employment protections typically bar terminations of senior workers except under very limited circumstances, the wrongful-discharge doctrines recognized in the United States provide no such formal employment security. Rather, they make it feasible for certain workers to litigate after termination at considerable monetary and psychic cost, and with limited certainty of redress. By raising expected employment costs of senior workers without providing them formal job security, U.S. wrongful-discharge laws may make it more likely that employment of protected groups is ultimately reduced.

disproportionate share of the unemployed, this explanation is consistent with Kugler and Saint Paul's (forthcoming) finding that exit rates from unemployment slow after states adopted implied-contract doctrines.

${ }^{29}$ Hence, these specifications are identical to column 5 of Table 5 but are estimated separately by demographic group. Estimates using an alternative long-run post-period of years 7 and 8 following adoption produced qualitatively similar results and are available on request.

${ }^{30}$ The exception to the claims of the last two sentences is caused by the relatively large negative (albeit statistically insignificant) long-term effect from the implied-contract exception for young, low-education males (column 2 of Table 7). 


\section{Reconciling with previous studies}

Our finding that unjust-dismissal laws - the implied-contract exception in particular - have had a modest but economically meaningful adverse impact on state employment rates stands in contrast to two published papers exploring the same questions. The first, a widely cited study by Dertouzos and Karoly (1992 and 1993, D\&K hereafter), found that states' adoption of exceptions to employment at will over 1980 to 1987 reduced aggregate state employment by 4 to 5 percentage points, with even larger reductions in employment in the service and financial sectors. The magnitude of these estimates, roughly three to five times as large as our estimates, garnered considerable attention in academic journals and policy debates. ${ }^{31}$ More recently, Thomas Miles (2000), using a methodology more comparable to our own, found no effect of unjust-dismissal doctrines on aggregate employment or unemployment. To understand the source of the discrepancies between these two studies and our own findings, we reanalyzed both papers.

\section{A. The Dertouzos and Karoly study}

Our difference-in-difference methodology estimates the impacts of wrongful-discharge doctrines by contrasting contemporaneous employment and wage changes in adopting versus non-adopting states. D\&K eschew this source of variation, arguing that the adoption of state laws may be driven by the "supply and demand' for legal doctrines. To correct for this postulated endogeneity, D\&K employ a set of instrumental variables to predict states' adoption of wrongfuldischarge doctrines and then use these predicted values in place of the actual laws.

Specifically, D\&K estimate an equation of the form

$$
\ln \left(e m p_{s t}\right)=\alpha+\gamma \cdot \hat{L}_{j t}+\phi_{\mathrm{s}}+\delta_{t}+\varepsilon_{s t},
$$

where $\ln e m p_{s t}$ is log total employment in state $s$ and year $t$, and $\hat{L}_{j t}$ is the predicted probability of the presence of each doctrine in the state and year. This predicted probability is estimated from a log odds regression of the observed law variables, $L_{j t}$, on a set of instrumental variables, $Z_{s t}$, and vector of year

\footnotetext{
${ }^{31}$ For example, during his gubernatorial campaign, California Governor Pete Wilson prominently cited Dertouzos and Karoly's conclusions in support of tort reform (Hopper, 1995).
} 
dummies $\delta_{t}$.

(3) $\quad \operatorname{Pr}\left[L_{s t}=1\right]=\operatorname{Pr}\left[Z_{s t}^{\prime} \beta+\delta_{t}>-\varepsilon_{s t}\right]$.

The instruments used by D\&K in estimating equation (3) include whether a state had a Republican governor, the state's level and change in union membership, the state's change in lawyers per capita, the fraction of bordering states recognizing a similar doctrine, and an indicator for whether a state had a right to work law in 1980. As D\&K's estimates of equation (3) indicate, these latter two variables are indeed highly correlated with states' propensity to adopt common law exceptions. A potential confound, however, is that both measures are also likely to have a direct correlation with employment levels that does not emanate from their influence on law adoption.

The source of our concern is visible in Figures 7 and 8. As noted by Blanchard and Katz (1992) and depicted in Figure 7, employment growth in the South has exceeded that in the non-South for the past six decades. This trend substantially predates the adoption of unjust dismissal laws and likely stems from factors including the advent of air conditioning (which increased habitability and manufacturing productivity in the South, most notably in tobacco and printing), and civil-rights-era legislation that increased wages and employment of Southern blacks (Arsenault, 1984; Donohue and Heckman, 1991). ${ }^{32}$ Moreover, as is shown in Figure 8, Southern states were last and least likely to adopt wrongfuldischarge doctrines, meaning that their fraction of bordering states adopting exceptions was also much lower. Furthermore, 85 percent of Southern states had a right-to-work law in 1980 versus only 25 percent of nonSouthern states. ${ }^{33}$

Given the positive correlation between Southern region and employment growth and the negative correlation between Southern region and adoption of wrongful-discharge doctrines, it is a near certainty that

\footnotetext{
32 There is no formal agreement on which are the Southern states. We use Alabama, Arizona, Florida, Georgia, Kentucky, Louisiana, Mississippi, New Mexico, North and South Carolina, Tennessee, Texas, and Virginia. NonSouthern states include all other U.S. states except for DC and, due to lack of employment data extending to 1939 , Alaska, Hawaii, Illinois, Michigan, and Minnesota. Growth rates calculated in Figure 7 use each state's share of South or non-South employment in 1939 as base weights.
} 
equation (2), a regression of state employment growth on predicted law adoption, will indicate that wrongful-discharge laws reduce employment $(\hat{\gamma}<0)$. Intuitively, because the relative probability of adopting an exception is lower in the South (relative to the non-South) while relative employment growth is higher, D\&K's instrumental variable estimates will indicate that wrongful-discharge reduce employment levels. Yet, this correlation may primarily arise because wrongful-discharge laws were adopted in states that had been experiencing slower growth for decades. If this concern is well founded, the solution is also straightforward: permitting each state to assume its own time trend in employment will control for smooth growth rates that are otherwise a potential source of bias. ${ }^{34}$

To explore this possibility, we made a substantial effort to replicate D\&K's core results using their cited data sources, classification of case law, and empirical methods. While unfortunately, we were unable to reproduce their findings exactly, we believe our results are sufficiently comparable to allow us to explore the main substantive issues. ${ }^{35}$ Table 8 presents a summary of the findings. The first column replicates D\&K's basic instrumental-variables specification. This specification estimates the impact of three wrongful-discharge laws on the log of state employment during 1980 - 1987: the Implied-contract exception or Good-faith exception with contract remedy (IC/GF), the broad Public-policy or Good-faith exception with tort remedy (PP/GF), and the narrow Public-policy exception (NPP). ${ }^{36}$ The estimated impact of these doctrines on state employment is quite large. The IC/GF doctrine is estimated to reduce employment by close to 4.5 percentage points and the PP/GF doctrine by an additional 3.0 percentage

\footnotetext{
33 These patterns are abundantly evident in Tables 3.3 and 3.4 of D\&K (1992), which contain their first stage IV estimates. In all specifications, the fraction of neighboring states adopting a given doctrine is a strong positive predictor of own-state adoption, and the presence of a right-to-work law is a strong negative predictor.

${ }^{34}$ Where the fixed-effects estimator controls for fixed state differences in the level of employment, adding a linear trend controls for fixed state differences in trends in employment growth.

${ }^{35}$ D\&K did not provide their original data or programs but kindly shared their mapping of state borders developed for the IV estimates. Disconcertingly, we uncovered more than a dozen coding errors in this mapping. In addition, D\&K somewhat unconventionally coded Alaska as bordering Idaho, Oregon, Montana, and Washington state, and Hawaii as bordering California, Nevada, and Oregon. In the service of replication, we employ their original mapping.

${ }^{36}$ The first stage estimates for these models (estimates available from the authors) replicate the central pattern noted above from D\&K's models: the fraction of neighboring states adopting a given doctrine is a strong positive predictor of own-state adoption, and the presence of a right-to-work law is a strong negative predictor.
} 
points. Both coefficients are statistically significant. ${ }^{37}$

To the degree that the instrumented state-law variables are simply proxying persistent employment trends as suggested above, inclusion of linear state trend variables will reduce this source of bias. Column 2 adds these trends and an F-test of their joint significance rejects the null hypothesis at well below the 1 percent level. Inclusion of the trend variables reduces the magnitude of the estimated impacts of the state laws by approximately 60 percent and renders the coefficients insignificant. Notably, the standard errors of the law variables are little affected, indicating that the trend variables are not simply introducing collinearity that reduces the precision of the estimates. These results suggest that the D\&K estimates are substantially biased.

The subsequent two columns of Table 8 provide an additional specification check. One unusual control included in D\&K's estimates of equation (2) is the log of state gross product (and its change). Controlling for this variable is difficult to justify; if unjust dismissal laws reduce employment, they are likely to reduce output as well. ${ }^{38}$ Column 3 drops the output variable from the basic D\&K model, yielding large and difficult to interpret coefficients on the instrumented law variables. Apparently, the estimates are quite sensitive to inclusion of this variable. Notably, when in column 4 state trends are added to the model excluding the state output measure, the estimated impacts of the laws return to reasonable magnitudes and are in this case insignificant. These findings again suggest that the D\&K IV approach is non-robust.

To contrast the D\&K IV approach to our difference-in-difference methodology, we estimate in panel B of Table 8 a series of models in which we use as above the actual law changes $L_{s t}$ as independent variables rather than their predicted values but continue to use D\&K's coding of the law and other dependent and

\footnotetext{
${ }^{37}$ As noted, our replication results differ from D\&K. While they find (Table 5.2) that the PP/GF doctrine has the largest negative impact on employment (2.1 log points versus $1.4 \log$ points), we find a larger impact on IC/GF. Our estimates for the NPP doctrine are quite comparable. Following D\&K, we do not use a true IV procedure but insert predicted values from the first-stage (predictive) equation into the second stage estimates. This procedure is likely to exaggerate the precision of the estimates because it does not account for the fact that the independent variables are predicted rather than observed. In addition, we follow D\&K in not including all covariates from the second stage estimates in the first stage models (in particular, the first stage estimates exclude state dummies). This method again violates standard practice.
} 
independent variables. In column 1 of the second panel, we find a positive and significant effect of the IC/GF doctrine on state employment levels, opposite to D\&K's IV estimates. However, when we condition on state specific trends, this effect reverses sign and becomes negatively significant at 0.8 percentage points.

Because of our concern about the validity of conditioning on state output in these employment models, we drop the output measures in the final two columns. This yields estimates that are more stable and also more consistent with our findings above. Without conditioning on state trends, we find a small negative impact on the IC/GF doctrine on state employment. Adding trends, the magnitude increases to -1.5 percent, roughly one-third the size of the D\&K IV estimate but comparable to our estimates from Table 2.

In summary, we believe that a more appropriate treatment of D\&K's data leads to essentially the same conclusions as our analysis in Section III. By contrast, our reanalysis of the D\&K methodology does not support D\&K's findings of very large adverse employment effects of wrongful-discharge laws, nor does it confirm the validity of their conclusion that good-faith and tort doctrines are the source of these adverse effects.

\section{B. The importance of legal classification: The Thomas Miles study:}

In a careful recent study, Thomas Miles (2000) concluded that wrongful-discharge laws had no effect on aggregate employment or unemployment for the years 1964 to 1995. Using Miles's original data, we replicated these findings to understand the source of the discrepancies. ${ }^{39}$ Of the potential causes we explored, one was found to be consequential: the classification of case law developed by Walsh and Schwarz (1996) and used in the Miles study. Simply using the Miles data and specifications but replacing the Walsh-Schwarz legal variables with our own led to the inference that the implied-contract exception had

\footnotetext{
${ }^{38}$ In fact, wages paid by state are an input into the Bureau of Economic Analysis' calculations of gross state product. (see http://www.bea.gov/bea/regional/data.htm). Hence, the GSP measure is almost certain to have a mechanical correlation with state employment.

${ }^{39}$ We thank Thomas Miles for generous assistance with data and questions. Key differences from our approach are that the Miles study: 1) used a classification of case law developed by Walsh and Schwarz (1996); 2) used as a dependent variable log state employment (like Dertouzos and Karoly); 3) did not test a specification that included state-specific employment trends; 4) employed a sample that extended from 1964 to 1994; 5) used unweighted as
} 
reduced employment in adopting states. ${ }^{40}$

While this finding resolves the proximate puzzle, it raises a deeper concern. Do our findings hinge on technical points of case law where other scholars could readily disagree? To answer this question, we compared the findings using our own ('ADS') legal classification to the set of results we would have obtained using the classifications of wrongfuldischarge law developed by all other previous authors. These include: Dertouzos and Karoly (1992), Morriss (1995), and Walsh and Schwarz (1996, WS hereafter). To perform this test, we coded each previous classification and estimated a set of models for log state employment to population rates comparing the results from each. To follow the earlier analyses, we aggregate our data to annual (rather than monthly) observations and apply the long panel difference-indifference approach. ${ }^{41}$ Specifically, we estimate a model of the form

$$
\ln (e m p / p o p)_{s t j}=\alpha+\gamma \cdot L_{j t}+\phi_{\mathrm{s}}+\delta_{t}+\pi_{j}+\varepsilon_{s t},
$$

where the dependent variable is the log employment to population ratio of the eight demographic groups used in the previous models, and $\phi_{\mathrm{s}}, \delta_{t}$, and $\pi_{j}$ are main effects for states, years and demographic groups. In keeping with our concern about state and regional employment trends, we also estimate a specification that includes linear time trends for each state and demographic group. Because each legal classification scheme was compiled for a different time period - reflecting the point at which the researchers completed their studies - we present the results of regressions run over the same time period used by the other scholars. This provides a pure test of the importance of the differences in the alternative legal classifications. Table 9 presents these results.

Panel A of the table presents baseline estimates using the ADS classification for the full period of our sample, 1978 to 1999. Consistent with our estimates of equation (1) in Tables 1 and 2, we find a negative impact of both the implied-contract and good-faith doctrines on state employment rates. The second

opposed to population-weighted regressions; and 6) included a number of state, demographic and policy covariates absent from our analysis, such as the fraction of neighboring states recognizing a given doctrine.

${ }^{40}$ A table of replication results is available from the authors.

${ }^{41}$ Morriss (1995) also uses monthly data. The other authors do not. 
specification adds controls for state and demographic trends. As above, we find that the impact of the implied-contract doctrine is robust to these trend measures while the good-faith doctrine is not.

Panel B of the table presents estimates of four models using the years, 1978 - 1989, the time period for which we have the Morriss legal classification scheme. Whether we used our legal scheme or Morriss' has very little impact on the regression coefficients for the three legal exceptions. The implied-contract doctrine is shown to have a negative and statistically significant effect on the employment rate in all four regressions. Similarly, there is little variance in the estimates for the public-policy exception, which change little across columns and are wholly insignificant in all four regressions. Both classifications also show a statistically negative effect of the good-faith doctrine on employment for the period 1978 and 1989, but in neither case is this finding robust to state and demographic trend controls.

Panel C compares the ADS to the D\&K classification (now for the slightly shorter 1980 - 1987 time period used by $\mathrm{D} \& \mathrm{~K})$ and reveals a generally similar pattern. If one compares the two models that include the state and demographic group time trends, columns 2 and 4 of panel $\mathrm{C}$, the direction of the findings remains the same, though the ADS coefficients are larger. Since greater noise in the coding of these independent variables would tend to attenuate the point estimates, the finding that our effects tend to be larger may suggest that the ADS coding is somewhat more precise.

In the final panel, we compare our results with the Walsh and Schwarz (WS) scheme for the years 1978 to 1994 (i.e., the beginning of the ADS sample to the end the WS sample). As with our discussion of the Miles' results, the greatest discrepancies are found here. Using the WS classification, we find that the implied-contract exception has a positive albeit insignificant effect on employment levels in both specifications. In our assessment, this discrepancy potentially derives from a number of overt deficiencies in the WS classification. This classification appears to overlook leading cases and misclassify several others. To test the possible importance of these shortcomings, we correct only what we view as the six leading flaws in the WS classification. As is visible in the final columns of Table 9, these corrections almost entirely account for the discrepancies between the WS and ADS results.

To summarize, in two of three instances, our primary results are robust to the use of wrongful-discharge 
classification schemes developed by other authors. In the one case where our results substantially differ, we believe this can be traced to important oversights by the scholars who developed the classification.

\section{Conclusion}

We find ourselves taking a middle position between those who suggest that the adoption of exceptions to employment at will has had a major negative impact on employment (particularly Dertouzos and Karoly, 1992) and those who submit that the exceptions have had no impact (Miles, 2000). We find a statistically significant negative impact on employment, but it emanates from only one of the legal exceptions - the implied-contract doctrine - and its adoption causes a decline of from 0.8 to 1.7 percent in the ratio of employment to population, which is between one-third and one-fifth the estimated magnitude offered by Dertouzos and Karoly.

While the matter can never be free from doubt in statistical studies of this kind, the robustness of our findings across a number of different specifications, demographic groups, time periods, and classifications of the case law suggests that our findings have uncovered a true causal effect of adoption of the impliedcontract exception. At the same time, our findings also suggest that the impact of the implied-contract exception for the ten states that adopted it after 1987 has fallen substantially when compared to the estimated effect for the 33 states adopting between 1980 and 1987. We are uncertain whether this implies that the early adopters had a more aggressive legal posture than the later adopters (a cohort effect) or whether the ability to shift employment away from an implied-contract state simply dampens over time as more states adopt the exception (a substitution effect). If the latter, then our modest estimates of the negative impact on employment would slightly exaggerate the overall impact on employment because reductions in one state would to some extent lead to offsetting increases in employment in other states.

Those steeped in the view that low transaction costs would give rise to a Coasean invariance prediction might be surprised by the finding that the implied-contract doctrine reduces employment when it would seem simple changes to personnel policies could easily negate the legal effectiveness of this exception. Conversely, others might see the apparent inability to contract costlessly around legal rules as further confirmation that the invariance prediction of the Coase Theorem frequently does not obtain in labor 
markets (Donohue 1989). The declining effect of the implied-contract exception over time may suggest another possibility - that over time employers did learn how to fully circumvent the legal rule through appropriate disclaimers.

We stress that our paper does not attempt to provide an overall assessment of wrongful-discharge law. We have not offered any evaluation of the benefits of such laws to workers and the public. The fact that there is some reduction in employment - for women, younger workers, and less-educated men in the short term, and potentially for older and more educated workers in the longer term - underscores that legal protections do not come costlessly. Still, we see little robust evidence of a wage cost associated with the adoption of the implied-contract exception. Finally, we note that if workers valued the benefit of the implied-contract exception highly, one would expect to see a larger drop in wages because wage effects of the adverse demand shift caused by the burden to employers would be augmented by the benign supply shift caused by the perceived benefit to employees. The absence of a wage effect may imply that there was not a strong supply response to the implied-contract exception, suggesting that workers did not greatly value this benefit ex ante. 


\section{References}

Acemoglu, Daron and Joshua Angrist. 2001. "Consequences of Employment Protection? The Case of the Americans with Disabilities Act.” Journal of Political Economy, 109(5), October, 915 - 957.

Aghion, Phillipe and Benjamin Hermalin. 1990. "Legal Restrictions on Private Contracts can Enhance Efficiency.” Journal of Law, Economics, and Organizations. 6(2), Fall, 381 - 409.

Angrist, Joshua D. and Alan B. Krueger. 1999. "Empirical Strategies in Labor Economics." In Orley C. Ashenfelter and David Card, editors, Handbook of Labor Economics, volume 3, Netherlands: North-Holland.

Arsenault, Raymond. 1994. "The End of the Long Hot Summer: The Air Conditioner and Southern Culture." The Journal of Southern History, 50(4), 597 - 628.

Autor, David H. forthcoming 2003. "Outsourcing at Will: The Contribution of Unjust Dismissal Doctrine to the Growth of Employment Outsourcing." Journal of Labor Economics.

Bertola, Giuseppe, Francine Blau and Lawrence Kahn. 2002. "Labor Market Institutions and Demographic Employment Patterns.” mimeograph, European University Institute, June.

Bertrand, Marianne, Esther Duflo and Sendhil Mullainathan. 2002. "How Much Should We Trust Difference-in-differences Estimates?” NBER Working Paper \#8841, March.

Blanchard, Olivier Jean and Lawrence F. Katz. 1997. "What We Know and Do Not Know About the Natural Rate of Unemployment," Journal of Economic Perspectives, 11, 51 - 72.

Blanchard, Olivier Jean and Lawrence F. Katz. 1992. "Regional Evolutions.” Brookings Papers on Economic Activity, 1.

Blanchard, Olivier Jean and Pedro Portugal. 2000. "What Hides Behind an Unemployment Rate: Comparing Portuguese and U.S. Labor Markets.” American Economic Review, 91(1), 187 - 207.

Blanchard, Olivier Jean and Justin Wolfers. 1999. "The Role of Shocks and Institutions in the Rise of European Unemployment: The Aggregate Evidence.” The Economic Journal. 110, March, C31 C33.

Chandra, Amitabh. 2002. "Is the Convergence in the Racial Wage Gap Illusory?" mimeograph, Dartmouth College, January.

DeLeire, Thomas. 2000. "The Wage and Employment Effects of the Americans with Disabilities Act." Journal of Human Resources, 35(4), 693 - 715.

Dertouzos, James N., Elaine Holland, and Patricia Ebener. 1988. The Legal and Economic Consequences of Wrongful Termination. Santa Monica, CA: Rand.

Dertouzos, James N. and Lynn A. Karoly.1992. Labor-Market Responses to Employer Liability. Santa Monica, CA: Rand. 
Dertouzos, James N. and Lynn A. Karoly. 1993. "Employment Effects of Worker Protection: Evidence from the United States." in Christoph F. Buechtemann, editor. Employment Security and Labor Market Behavior: Interdisciplinary Approaches and International Evidence. Ithica, NY: ILR Press.

Donohue, John J. III. 1989. "Diverting the Coasean River: Incentive Schemes to Reduce Unemployment Spells,” 99, Yale Law Journal, 549.

Donohue, John J. III. 1998. “Did Miranda Diminish Police Effectiveness?” 50, Stanford Law Review, 1147.

Donohue, John J. III and James Heckman. 1991. "Continuous versus Episodic Change: The Impact of Civil Rights Policy on the Economic Status of Blacks." Journal of Economic Literature, 29, December, 1603 - 1643 .

Donohue, John J. III and Peter Siegelman. 1993. "Law and Macroeconomics: Employment Discrimination Litigation over the Business Cycle," Southern California Law Review, 66, 709-65.

Edelman, Lauren B., Steven E. Abraham, and Howard S. Erlanger. 1992. "Professional Construction of Law: The Inflated Threat of Wrongful-discharge," Law \& Society Review, 26, 47-83.

Gruber, Jonathan. 1994. "The Incidence of Mandated Maternity Benefits.” American Economic Review, $84(3), 622-41$.

Hahn, Jinyong, Petra Todd, and Wilbert van der Klaauw. 2001. "Identification and Estimation of Treatment Effects with a Regression-Discontinuity Design,” Econometrica, 69(1), 201-209.

Hoerr, John, Willaim G. Glaberson, Daniel B. Moskowitz, Vicky Cahan, Michael A.Pollaock, and Jonathan Tasini. 1985. "Beyond Unions: A Revolution in Employment Rights is in the Making." Business Week, July 8, $72-77$.

Hopper, Martyn. 1995. “California Needs Tort Reform.” The Sacramento Bee, June 10.

Jolls, Christine. 2000. “Accommodation Mandates,” Stanford Law Review, 53(2), 223 - 306.

Jung, David. J. and Richard Harkness.1988. “The Facts of Wrongfuldischarge,” Labor Lawyer, 4, 257.

Kamiat, Walter. 1996. "Labor and Lemons: Efficient Norms in the Internal Labor Market and the Possible Failures of Individual Contracting," University of Pennsylvania Law Review, 144, 1953.

Krueger, Alan B. 1991. "The Evolution of Unjust-Dismissal Legislation in the United States," Industrial \& Labor Relations Review, 44(4), 644-660.

Kugler, Adriana and Gilles Saint-Paul. Forthcoming. "How Do Firing Costs Affect Worker Flows in a World with Adverse Selection?” Journal of Labor Economics..

Lazear, Edward P. 1991. “Job Security Provisions and Employment." Quarterly Journal of Economics, 105(3), $699-726$.

Levine, David I. 1991. "Just-Cause Employment Policies in the Presence of Worker Adverse Selection," Journal of Labor Economics, 9, 294 - 305. 
Lindbeck and Snower. 1988. "Cooperation, Harassment, and Involuntary Unemployment: An InsiderOutsider Approach." American Economic Review, 78(1), 167 - 188.

Madrian, Brigitte C. and Lars Lefrgen. 2000. "An Approach to Longitudinally Matching Current Population Survey (CPS) Respondents.” Journal of Economics and Social Measurement, 26(1), 31 - 62.

Miles, Thomas J. 2000. "Common Law Exceptions to Employment at Will and U.S. Labor Markets." Journal of Law, Economics and Organizations, 16(1), 74 - 101.

Morriss, Andrew P. 1995. "Developing a Framework for Empirical Research on the Common Law: General Principles and Case Studies of the Decline of Employment-at-Will," Case Western Reserve Law Review, 45, 999 - 1148.

OECD Employment Outlook: 1999. 1999. Paris, France: OECD.

Olson, Walter (1997) The Excuse Factory: How Employment Law is Paralyzing the American Workplace. (New York: Free Press).

Oyer, Paul and Scott Schaefer. 2000. "Layoffs and Litigation." Rand Journal of Economics, 32(2), Summer, $345-358$.

Oyer, Paul and Scott Schaefer. 2002 "Litigation Costs and Returns to Experience." American Economic Review, 92(3), 683 - 705.

Saint Paul, Gilles. 2002. "The Political Economy of Employment Protection.” Journal of Political Economy, 110(3), 672 - 704.

Schwab, Stewart J. 1996. "Wrongfuldischarge Law and the Search for Third-Party Effects," Texas Law Review, 74(7), 1943 - 1978.

Schwab, Stewart J. 1993. "Life-Cycle Justice: Accommodating Just Cause and Employment At Will," Michigan Law Review, 92(1), 8 - 62.

Summers, Lawrence H. 1989. "Some Simple Economics of Mandated Benefits." American Economic Review, 79(2), May, 177 - 183.

Walsh, David J. and Joshua L. Schwarz. 1996. "State Common Law Wrongful-discharge Doctrines: UpDate, Refinement, and Rationales.” American Business Law Journal, 33, 645 - 689.

Willborn, Steven L., Stewart J. Schwab and John F. Burton, Jr. 1998. Employment Law: Cases and Materials. Charlottesville, VA: Lexis Law Publishing (2nd. ed.). 


\section{Legal Appendix}

\begin{tabular}{|c|c|c|c|}
\hline State & Public Policy & Implied Contract & Good Faith \\
\hline Alabama & & $\begin{array}{l}\text { Hoffman-LaRoche v. Campbell, } 512 \\
\text { So. 2d } 725 \text { (Ala. } 1987 \text { July). }\end{array}$ & \\
\hline Alaska & $\begin{array}{l}\text { Knight v. American Guard \& Alert, } 714 \\
\text { P.2d } 788 \text { (Alaska } 1986 \text { February). }\end{array}$ & $\begin{array}{l}\text { Eales v. Tanana Valley Medical } \\
\text { Surgical Group, } 663 \text { P.2d } 958 \text { (Alaska } \\
1983 \text { May). }\end{array}$ & $\begin{array}{l}\text { Mitford v. Lasala, } 666 \text { P.2d } 1000 \\
\text { (Alaska } 1983 \text { May). }\end{array}$ \\
\hline Arizona & $\begin{array}{l}\text { Wagenseller v. Scottsdale Memorial } \\
\text { Hosp., } 710 \text { P.2d } 1025 \text { (Ariz. } 1985 \text { June). }\end{array}$ & $\begin{array}{l}\text { Leikvold v. Valley View Community } \\
\text { Hosp., } 688 \text { P.2d } 201 \text { (Ariz. App. } 1983 \\
\text { June), vacated, } 688 \text { P.2d } 170 \text { (Ariz. } \\
\text { 1984). }\end{array}$ & $\begin{array}{l}\text { Wagenseller v. Scottsdale Memorial } \\
\text { Hosp., } 710 \text { P.2d } 1025 \text { (Ariz. } 1985 \\
\text { June). }\end{array}$ \\
\hline Arkansas & $\begin{array}{l}\text { MBM Co. v. Counce, } 596 \text { S.W.2d } 681 \\
\text { (Ark. } 1980 \text { March). }\end{array}$ & $\begin{array}{l}\text { Jackson v. Kinark Corp., } 669 \text { S.W.2d } \\
898 \text { (Ark. } 1984 \text { June). D\& K uses } \\
\text { Griffen v. Erickson, 642 S.W.2d } 308 \\
\text { (Ark. 1982). }\end{array}$ & \\
\hline California & $\begin{array}{l}\text { Petermann v. Int'1 Brotherhood of } \\
\text { Teamsters, } 344 \text { P.2d } 25 \text { (Cal. Ct. App. } \\
1959 \text { September). }\end{array}$ & $\begin{array}{l}\text { Drzewiecki v. H\&R Block, } 101 \text { Cal. } \\
\text { Rptr. } 169 \text { (Cal. Ct. App. } 1972 \text { March). }\end{array}$ & $\begin{array}{l}\text { Cleary v. American Airlines, } 168 \\
\text { Cal. Rptr. } 722 \text { (Cal. Ct. App. } 1980 \\
\text { October), modified to remove tort } \\
\text { damages by Foley v. Interactive } \\
\text { Data Corp., } 765 \text { P.2d } 373 \text { (Cal. } \\
\text { 1988). }\end{array}$ \\
\hline Colorado & $\begin{array}{l}\text { Winther v. DEC Int'1 Inc., } 625 \text { F. Supp. } \\
100 \text { (D. Colo. } 1985 \text { September). D\& K } \\
\text { uses Cronk v. Inter-Mountain Rural } \\
\text { Electric Ass'n., } 765 \text { P.2d } 619 \text { (Colo. Ct. } \\
\text { App. 1988). }\end{array}$ & $\begin{array}{l}\text { Brooks v. TWA, } 574 \text { F. Supp. } 805 \text { (D. } \\
\text { Colo. } 1983 \text { October). D\& K uses Salimi } \\
\text { v. Farmers Ins. Group, } 684 \text { P.2d } 619 \\
\text { (Colo. Ct. App. 1988). }\end{array}$ & \\
\hline Connecticut & $\begin{array}{l}\text { Sheets v. Teddy's Frosted Foods, } 427 \\
\text { A.2d } 385 \text { (Conn. } 1980 \text { January). }\end{array}$ & $\begin{array}{l}\text { Finley v. Aetna Life, } 499 \text { A.2d } 64 \\
\text { (Conn. Ct. App. } 1985 \text { October), } \\
\text { reversed on other grounds, } 520 \text { A.2d } \\
208 \text { (Conn. 1987) (upholding implied } \\
\text { contract exception) D\&K uses } \\
\text { Magnan v. Anaconda Indus., } 479 \\
\text { A.2d } 781 \text { (Conn. 1984). }\end{array}$ & $\begin{array}{l}\text { Magnan v. Anaconda Indus., } 429 \\
\text { A.2d } 492 \text { (Conn. Super. Ct. } 1980 \\
\text { June), reversed on other grounds, } \\
479 \text { A.2d } 781 \text { (Conn. 1984). D\&K } \\
\text { uses Cook v. Alexander \& } \\
\text { Alexander, 588 A.2d } 1295 \text { (Conn. } \\
\text { Ct. App. 1985). }\end{array}$ \\
\hline Delaware & $\begin{array}{l}\text { Henze v. Alloy Surfaces (Del. } 1992 \\
\text { March). D\&K uses no case. }\end{array}$ & & $\begin{array}{l}\text { Merril v. Crothall-American, } 606 \\
\text { A.2d } 96 \text { (Del. Sup. Ct. } 1992 \text { April). } \\
\text { D\&K uses no case. }\end{array}$ \\
\hline \multicolumn{4}{|l|}{ Florida } \\
\hline \multicolumn{4}{|l|}{ Georgia } \\
\hline Hawaii & $\begin{array}{l}\text { Parnar v. Americana hotels, } 652 \text { P.2d } \\
625 \text { (Haw. } 1982 \text { October). }\end{array}$ & $\begin{array}{l}\text { Kinoshita v. Canadian Pacific Airlines, } \\
724 \text { P.2d } 110 \text { (Haw. } 1986 \text { August). }\end{array}$ & \\
\hline Idaho & $\begin{array}{l}\text { Jackson v. Minidoka Irrigation District, } \\
563 \text { P.2d } 54 \text { (Idaho } 1977 \text { April). }\end{array}$ & $\begin{array}{l}\text { Jackson v. Minidoka, } 563 \text { P.2d } 54 \\
\text { (Idaho } 1977 \text { April). }\end{array}$ & $\begin{array}{l}\text { Metcalf v. Intermountain Gas. Co., } \\
778 \text { P.2d } 744 \text { (Idaho } 1989 \text { August). }\end{array}$ \\
\hline
\end{tabular}

Notes:

'D\&K' stands for Dertouzos and Karoly (1992).

Bold text indicates that our classification differs from D\&K. 


\begin{tabular}{|c|c|c|c|}
\hline State & Public Policy & Implied Contract & Good Faith \\
\hline Illinois & $\begin{array}{l}\text { Kelsay v. Motorola, } 384 \text { N.E.2d } 353 \text { (Ill. } \\
1978 \text { December). }\end{array}$ & $\begin{array}{l}\text { Carter v. Kaskaskia Community Action } \\
\text { Agency, } 322 \text { N.E.2d } 574 \text { (Ill. App. Ct. } \\
1974 \text { December). D\& K uses Duldulao } \\
\text { v. St. Mary of Nazareth Hosp. } \\
\text { Center, 505 N.E.2d } 314 \text { (IIl. 1987). }\end{array}$ & \\
\hline Indiana & $\begin{array}{l}\text { Frampton v. Central Indiana Gas Co, } \\
297 \text { N.E.2d } 425 \text { (Ind. } 1973 \text { May). }\end{array}$ & $\begin{array}{l}\text { Romak v. Public Service Co., } 511 \\
\text { N.E.2d } 1024 \text { (Ind. } 1987 \text { August). }\end{array}$ & \\
\hline Iowa & $\begin{array}{l}\text { Northrup v. Farmland Ind., } 372 \text { N.W.2d } \\
193 \text { (Iowa } 1985 \text { July). }\end{array}$ & $\begin{array}{l}\text { Young v. Cedar County Work Activity } \\
\text { Center, } 418 \text { N.W.2d } 844 \text { (Iowa } 1987 \\
\text { November). }\end{array}$ & \\
\hline Kansas & $\begin{array}{l}\text { Murphy v. City of Topeka, } 630 \text { P.2d } 186 \\
\text { (Kan. Ct. App. } 1981 \text { June). }\end{array}$ & $\begin{array}{l}\text { Allegri v. Providence-St. Margaret } \\
\text { Health Center, } 684 \text { P.2d } 1031 \text { (Kan. Ct. } \\
\text { App. } 1984 \text { August). }\end{array}$ & \\
\hline Kentucky & $\begin{array}{l}\text { Firestone Textile Co. v. Meadows, } 666 \\
\text { S.W.2d } 730 \text { (Ky. } 1983 \text { November). }\end{array}$ & $\begin{array}{l}\text { Shah v. American Synthetic Rubber } \\
\text { Co., } 655 \text { S.W.2d } 489 \text { (Ky. } 1983 \\
\text { August). D\& K has no case. }\end{array}$ & \\
\hline Louisiana & & & $\begin{array}{l}\text { Barbe v. A.A. Harmon \& Co, } 705 \\
\text { So. 2d } 1210 \text { (La. } 1998 \text { January). } \\
\text { D\& K has no case. }\end{array}$ \\
\hline Maine & & $\begin{array}{l}\text { Terrio v. Millinocket Community } \\
\text { Hospital, } 379 \text { A.2d } 135 \text { (Me. } 1977 \\
\text { November). D\& K uses Larrabee v. } \\
\text { Penobscot Frozen Foods, } 486 \text { A.2d } 97 \\
\text { (1984). }\end{array}$ & \\
\hline Maryland & $\begin{array}{l}\text { Adler v. American Standard Corp., } 432 \\
\text { A.2d } 464 \text { (Md. } 1981 \text { July). }\end{array}$ & $\begin{array}{l}\text { Staggs v. Blue Cross, } 486 \text { A.2d } 798 \\
\text { (Md. Ct. Spec. App.), cert. denied, } 493 \\
\text { A.2d } 349 \text { (Md. } 1985 \text { January). }\end{array}$ & \\
\hline Massachusetts & $\begin{array}{l}\text { McKinney v. National Dairy Council, } \\
491 \text { F. Supp. } 1108 \text { (D. Mass. } 1980 \text { May). } \\
\text { D\& K uses Cort v. Bristol Meyers Co. } \\
\text { 431 N.E.2d } 908 \text { (Mass. 1982). }\end{array}$ & $\begin{array}{l}\text { Hobson v. McLean Hospital Corp., } 522 \\
\text { N.E.2d } 975 \text { (Mass. } 1988 \text { May). D\&K } \\
\text { uses Jackson v. Action for Boston } \\
\text { Comm. Dev., 525 N.E.2d } 411 \text { (Mass. } \\
\text { 1988). }\end{array}$ & $\begin{array}{l}\text { Fortune v. National Cash Register } \\
\text { Co., } 364 \text { N.E.2d } 1251 \text { (Mass. } 1977 \\
\text { July). }\end{array}$ \\
\hline Michigan & $\begin{array}{l}\text { Sventko v. Kroger, } 245 \text { N.W.2d } 151 \\
\text { (Mich. } 1976 \text { June). }\end{array}$ & $\begin{array}{l}\text { Toussaint v. Blue Cross, } 292 \text { N.W.2d } \\
880 \text { (Mich. } 1980 \text { June). }\end{array}$ & \\
\hline Minnesota & $\begin{array}{l}\text { Phipps v. Clark Oil \& Refining Co., } 396 \\
\text { N.W.2d } 588 \text { (Minn. Ct. App. } 1986 \\
\text { November), aff'd } 408 \text { N.W.2d } 569 \\
\text { (Minn. 1987). }\end{array}$ & $\begin{array}{l}\text { Pine River State Bank v. Mettille, } 333 \\
\text { N.W.2d } 622 \text { (Minn. } 1983 \text { April). }\end{array}$ & \\
\hline Mississippi & $\begin{array}{l}\text { Laws v. Aetna Finance Co., } 667 \text { F. Supp. } \\
342 \text { (N.D. Miss. } 1987 \text { July). D\& K use } \\
\text { no case. }\end{array}$ & $\begin{array}{l}\text { Bobbitt v. The Orchard, Ltd., } 603 \text { So. } \\
\text { 2d } 356 \text { (Miss. } 1992 \text { June). }\end{array}$ & \\
\hline Missouri & $\begin{array}{l}\text { Boyle v. Vista Eyewear, } 700 \text { S.W.2d } 859 \\
\text { (Mo. Ct. App. } 1985 \text { November). }\end{array}$ & $\begin{array}{l}\text { Arie v. Intertherm, } 648 \text { S.W.2d } 142 \\
\text { (Mo. Ct. App. } 1983 \text { January). } \\
\text { Exception overturned by Johnson v. } \\
\text { McDonnell Douglas Corp., } 745 \text { S.W.2d } \\
661 \text { (Mo. Sup. Ct. } 1988 \text { February). } \\
\text { D\& K includes Arie but not Johnson. }\end{array}$ & \\
\hline
\end{tabular}




\begin{tabular}{|c|c|c|c|}
\hline State & Public Policy & Implied Contract & Good Faith \\
\hline Montana & $\begin{array}{l}\text { Keneally v. Sterling Orgain, } 606 \text { P.2d } \\
127 \text { (Mont. } 1980 \text { January). }\end{array}$ & $\begin{array}{l}\text { Montana Wrongful Discharge from } \\
\text { Employment Act, Mont. Code Ann. 39- } \\
\text { 2-901 to } 914 \text { (1987 June). }\end{array}$ & $\begin{array}{l}\text { Gates v. Life of Montana Insurance } \\
\text { Co., } 638 \text { P.2d } 1063 \text { (Mont. } 1982 \\
\text { January). }\end{array}$ \\
\hline Nebraska & $\begin{array}{l}\text { Ambroz v. Cornhusker Square, } 416 \\
\text { N.W.2d } 510 \text { (Neb. } 1987 \text { November). }\end{array}$ & $\begin{array}{l}\text { Morris v. Lutheran Medical Center, } 340 \\
\text { N.W.2d } 388 \text { (Neb. } 1983 \text { November). }\end{array}$ & \\
\hline Nevada & $\begin{array}{l}\text { Hansen v. Harrah's, } 675 \text { P.2d } 394 \text { (Nev. } \\
1984 \text { January). }\end{array}$ & $\begin{array}{l}\text { Southwest Gas Corp. v. Ahmad, } 668 \\
\text { P.2d } 261 \text { (Nev. } 1983 \text { August). }\end{array}$ & $\begin{array}{l}\text { K-Mart Corp. v. Ponsock, } 732 \text { P.2d } \\
1364 \text { (Nev. } 1987 \text { February). }\end{array}$ \\
\hline $\begin{array}{r}\text { New } \\
\text { Hampshire }\end{array}$ & $\begin{array}{l}\text { Monge v. Beebe Rubber Co., } 316 \text { A.2d } \\
549 \text { (N.H. } 1974 \text { February) (only contract } \\
\text { damages); Cloutier v. A\&P, } 436 \text { A.2d } \\
1140 \text { (New Hamp. 1981) (allows tort } \\
\text { damages). }\end{array}$ & $\begin{array}{l}\text { Panto v. Moore Business Forms, } 547 \\
\text { A.2d } 260 \text { (N.H. } 1988 \text { August). }\end{array}$ & $\begin{array}{l}\text { Monge v. Beebe Rubber Co., } 316 \\
\text { A.2d } 549 \text { (N.H. } 1974 \text { February). } \\
\text { Eliminated as separate cause of } \\
\text { action in Howard v. Dorr Woolen } \\
\text { Co., } 414 \text { A.2d } 1273 \text { (N.H. } 1980 \\
\text { May). D\& K uses Monge but not } \\
\text { Howard. }\end{array}$ \\
\hline New Jersey & $\begin{array}{l}\text { Pierce v. Ortho Pharm. Corp., } 417 \text { A.2d } \\
505 \text { (N.J. } 1980 \text { July). }\end{array}$ & $\begin{array}{l}\text { Woolley v. Hoffmann-LaRoche, Inc., } \\
491 \text { A.2d } 1257 \text { (N.J. } 1985 \text { May). }\end{array}$ & \\
\hline New Mexico & $\begin{array}{l}\text { Vigil v. Arzola, } 699 \text { P.2d } 613 \text { (N.M. Ct. } \\
\text { App. } 1983 \text { July), reversed on other } \\
\text { grounds, } 687 \text { P.2d } 1038 \text { (N.M. 1984). }\end{array}$ & $\begin{array}{l}\text { Forrester v. Parker, } 606 \text { P.2d } 191 \text { (N.M. } \\
1980 \text { February). }\end{array}$ & \\
\hline New York & $\begin{array}{l}\text { None. D\& K uses Chin v. AT\&T, } 96 \\
\text { Misc. 2d 1070, } 410 \text { N.Y.S.2d } 737 \\
\text { (1978) (contract damages only), until } \\
\text { the public policy exception was clearly } \\
\text { rejected by NY's highest court in } \\
\text { Murphy v. American Home Products } \\
\text { Corp., } 448 \text { N.E.2d } 86 \text { (N.Y. 1983). }\end{array}$ & $\begin{array}{l}\text { Weiner v. McGraw-Hill, Inc., } 443 \\
\text { N.E.2d 441(N.Y. } 1982 \text { November). }\end{array}$ & \\
\hline North Carolina & $\begin{array}{l}\text { Sides v. Duke Univ., } 328 \text { S.E.2d } 818 \\
\text { (N.C. Ct. App. } 1985 \text { May). }\end{array}$ & & \\
\hline North Dakota & $\begin{array}{l}\text { Krein v. Marian Manor Nursing Home, } \\
415 \text { N.W.2d } 793 \text { (N.D. } 1987 \text { November). }\end{array}$ & $\begin{array}{l}\text { Hammond v. North Dakota State } \\
\text { Personnel Bd., } 345 \text { N.W.2d } 359 \text { (N.D. } \\
1984 \text { February). D\& K uses Bailey v. } \\
\text { Perkins Restaurants, Inc., } 398 \\
\text { N.W.2d } 120 \text { (N.D. 1986). }\end{array}$ & \\
\hline Ohio & $\begin{array}{l}\text { Adopted, Goodspeed v. Airborne } \\
\text { Express, Inc., } 121 \text { L.R.R.M. (BNA) } 3216 \\
\text { (Ohio Ct. App. } 1985 \text { February); } \\
\text { rejected, Phung v. Waste Management } \\
\text { Inc., } 491 \text { N.E.2d } 1114 \text { (Ohio } 1986 \\
\text { April); adopted, Greely v. Miami Valley } \\
\text { Maintenance Contractors, Inc., } 551 \\
\text { N.E.2d } 981 \text { (Ohio } 1990 \text { March). D\&K } \\
\text { does not include Greely. }\end{array}$ & $\begin{array}{l}\text { West v. Roadway Express, In.c, } 115 \\
\text { L.R.R.M. (BNA) } 4553 \text { (Ohio Ct. App. } \\
\text { 1982 April). }\end{array}$ & \\
\hline Oklahoma & $\begin{array}{l}\text { Burk v. K-Mart Corp., } 770 \text { P.2d } 24 \\
\text { (Okla. } 1989 \text { February). }\end{array}$ & $\begin{array}{l}\text { Langdon v. Saga Corp., } 569 \text { P.2d } 524 \\
\text { (Okla. Ct. App. } 1976 \text { December). D\& K } \\
\text { uses Hinson v. Cameron, } \mathbf{7 4 2} \text { P.2d } 24 \\
\text { (Okla. 1987). }\end{array}$ & $\begin{array}{l}\text { adopted, Hall v. Farmers Insurance } \\
\text { Exchange, } 713 \text { P.2d } 1027 \text { (Okla. } \\
1985 \text { May); rejected, Burk v. K- } \\
\text { Mart Corp., } 770 \text { P.2d } 24 \text { (Okla. } \\
1989 \text { February). D\&K gives no } \\
\text { case here. }\end{array}$ \\
\hline
\end{tabular}




\begin{tabular}{|c|c|c|c|}
\hline State & Public Policy & Implied Contract & Good Faith \\
\hline Oregon & $\begin{array}{l}\text { Nees v. Hocks, } 536 \text { P.2d } 512 \text { (1975 } \\
\text { June). }\end{array}$ & $\begin{array}{l}\text { Yartzoff v. Democrat-Herald Publ. Co., } \\
576 \text { P.2d } 356 \text { (Ore. } 1978 \text { March). }\end{array}$ & \\
\hline Pennsylvania & $\begin{array}{l}\text { Geary v. United States Steel Corp., } 319 \\
\text { A.2d } 174 \text { (Pa. } 1974 \text { March). D\&K uses } \\
\text { Reuther v. Fowler \& Williams, Inc., } \\
\text { 386 A.2d } 119 \text { (Pa. Super. Ct. 1978). }\end{array}$ & & \\
\hline Rhode Island & $\begin{array}{l}\text { None. D\&K uses Volino v. General } \\
\text { Dynamics, } 539 \text { A.2d } 531 \text { (R.I. 1988). }\end{array}$ & & \\
\hline South Carolina & $\begin{array}{l}\text { Ludwick v. This Minute of Carolina, } \\
\text { Inc., } 337 \text { S.E.2d } 213 \text { (S.C. } 1985 \\
\text { November). }\end{array}$ & $\begin{array}{l}\text { Small v. Springs Industries, Inc., } 357 \\
\text { S.E.2d } 452 \text { (S.C. } 1987 \text { June). }\end{array}$ & \\
\hline South Dakota & $\begin{array}{l}\text { Johnson v. Kreiser's Inc., } 433 \text { N.W.2d } \\
225 \text { (S.D. } 1988 \text { December) (contract } \\
\text { damages). D\& K uses Trombollo v. } \\
\text { Dunn, 342 N.W.2d } 23 \text { (1984). }\end{array}$ & $\begin{array}{l}\text { Osterkamp v. Alkota Mfg, Inc., } 332 \\
\text { N.W.2d } 275 \text { (S.D. } 1983 \text { April) }\end{array}$ & \\
\hline Tennessee & $\begin{array}{l}\text { Clanton v. Clain-Sloan Co., } 677 \text { S.W.2d } \\
441 \text { (Tenn. } 1984 \text { August). }\end{array}$ & $\begin{array}{l}\text { Hamby v. Genesco Inc., } 627 \text { S.W.2d } \\
373 \text { (Tenn. Ct. App. } 1981 \text { November). } \\
\text { D\& K cites no case. }\end{array}$ & \\
\hline Texas & $\begin{array}{l}\text { Sabine Pilot Serv. Inc. v. Hauck, } 672 \\
\text { S.W.2d } 322 \text { (Tex. Civ. App. } 1984 \text { June), } \\
\text { affirmed, } 687 \text { S.W.2d } 733 \text { (Tex. 1985). }\end{array}$ & $\begin{array}{l}\text { Johnson v. Ford Motor Co., } 690 \text { S.W.2d } \\
90 \text { (Tex. Civ. App. } 1985 \text { April). D\&K } \\
\text { cites no case. }\end{array}$ & \\
\hline Utah & $\begin{array}{l}\text { Berube v. Fashion Centre, } 771 \text { P.2d } 1033 \\
\text { (Utah } 1989 \text { March). }\end{array}$ & $\begin{array}{l}\text { Rose v. Allied Development, } 719 \text { P.2d } \\
83 \text { (Utah } 1986 \text { May). D\&K cites no } \\
\text { case. }\end{array}$ & \\
\hline Vermont & $\begin{array}{l}\text { Payne v. Rozendaal, } 520 \text { A.2d } 586 \text { (Vt. } \\
1986 \text { September). D\& K uses Jones v. } \\
\text { Keough, 409 A.2d } 581 \text { (Vt. 1979). }\end{array}$ & $\begin{array}{l}\text { Sherman v. Rutland Hospital, Inc. } 500 \\
\text { A.2d } 230 \text { (Vt. } 1985 \text { August). D\& K uses } \\
\text { Benoir v. Ethan Allen, Inc., 514 A.2d } \\
\mathbf{7 1 6} \text { (Vt. 1986). }\end{array}$ & \\
\hline Virginia & $\begin{array}{l}\text { Bowman v. State Bank of Keysville, } 331 \\
\text { S.E.2d } 797 \text { (Va. } 1985 \text { June). }\end{array}$ & $\begin{array}{l}\text { Frazier v. Colonial Williamsburg } \\
\text { Foundation, } 574 \text { F. Supp. } 318 \text { (E.D. Va. } \\
1983 \text { September). D\&K cites no case. }\end{array}$ & \\
\hline Washington & $\begin{array}{l}\text { Thompson v. St. Regis Paper Co., } 685 \\
\text { P.2d } 1081 \text { (Wash. } 1984 \text { July). D\&K uses } \\
\text { Roberts v. Atlantic Richfield Co., } 568 \\
\text { P.2d } 764 \text { (Wash. 1977). }\end{array}$ & $\begin{array}{l}\text { Roberts v. Atlantic Richfield Co., } 568 \\
\text { P.2d } 764 \text { (Wash. } 1977 \text { August). }\end{array}$ & \\
\hline West Virginia & $\begin{array}{l}\text { Harless v. First National Bank, } 246 \\
\text { S.E.2d } 270 \text { (W. Va. } 1978 \text { July). }\end{array}$ & $\begin{array}{l}\text { Cook v. Heck's Inc., } 342 \text { S.E.2d } 453 \\
\text { (W. Va. } 1986 \text { April). }\end{array}$ & \\
\hline Wisconsin & $\begin{array}{l}\text { Ward v. Frito-Lay, Inc., } 290 \text { N.W.2d } 536 \\
\text { (Wis. Ct. App. } 1980 \text { January). D\& K } \\
\text { uses Brockmeyer v. Dun \& Bradstreet, } \\
\text { 325 N.W.2d } 70 \text { (Wis. Ct. App. 1982). }\end{array}$ & $\begin{array}{l}\text { Ferraro v. Koelsch, } 368 \text { N.W.2d } 666 \\
\text { (Wis. } 1985 \text { June). }\end{array}$ & \\
\hline Wyoming & $\begin{array}{l}\text { Griess v. Consolidated Freightways, } 776 \\
\text { P.2d } 752 \text { (Wyo. } 1989 \text { July). D\& K uses } \\
\text { Allen v. Safeway Stores, Inc., } 699 \text { P.2d } \\
\mathbf{2 7 7} \text { (Wyo. 1985). }\end{array}$ & $\begin{array}{l}\text { Mobil Coal Producing Inc., v. Parks, } \\
704 \text { P.2d } 702 \text { (Wyo. } 1985 \text { August). }\end{array}$ & $\begin{array}{l}\text { Wilder v. Cody Country Chamber of } \\
\text { Commerce, } 868 \text { P.2d } 211 \text { (Wyo. } \\
1994 \text { January). }\end{array}$ \\
\hline
\end{tabular}




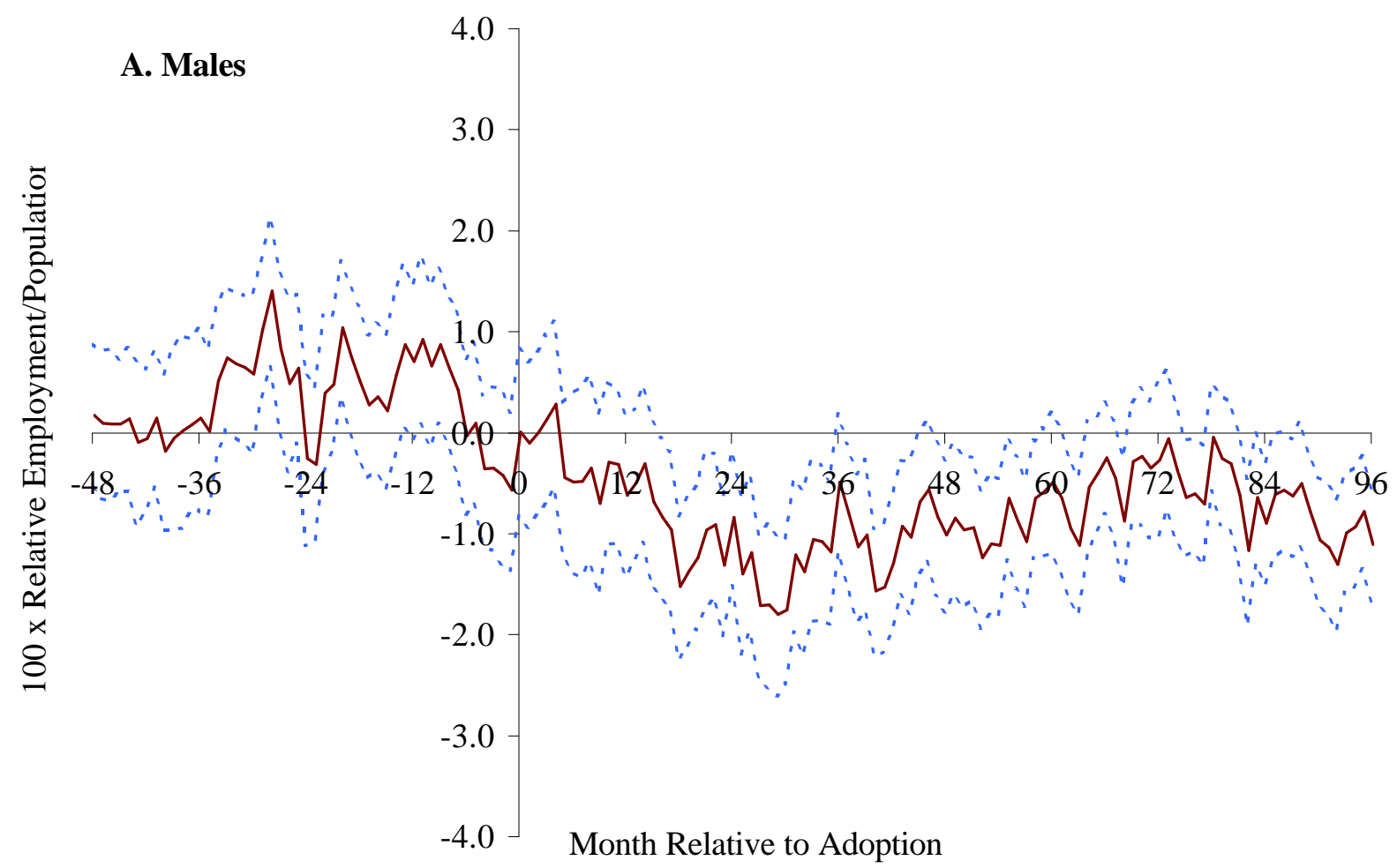

— Point Estimate $\quad$ - - - - Robust 90 Percent Confidence Interval

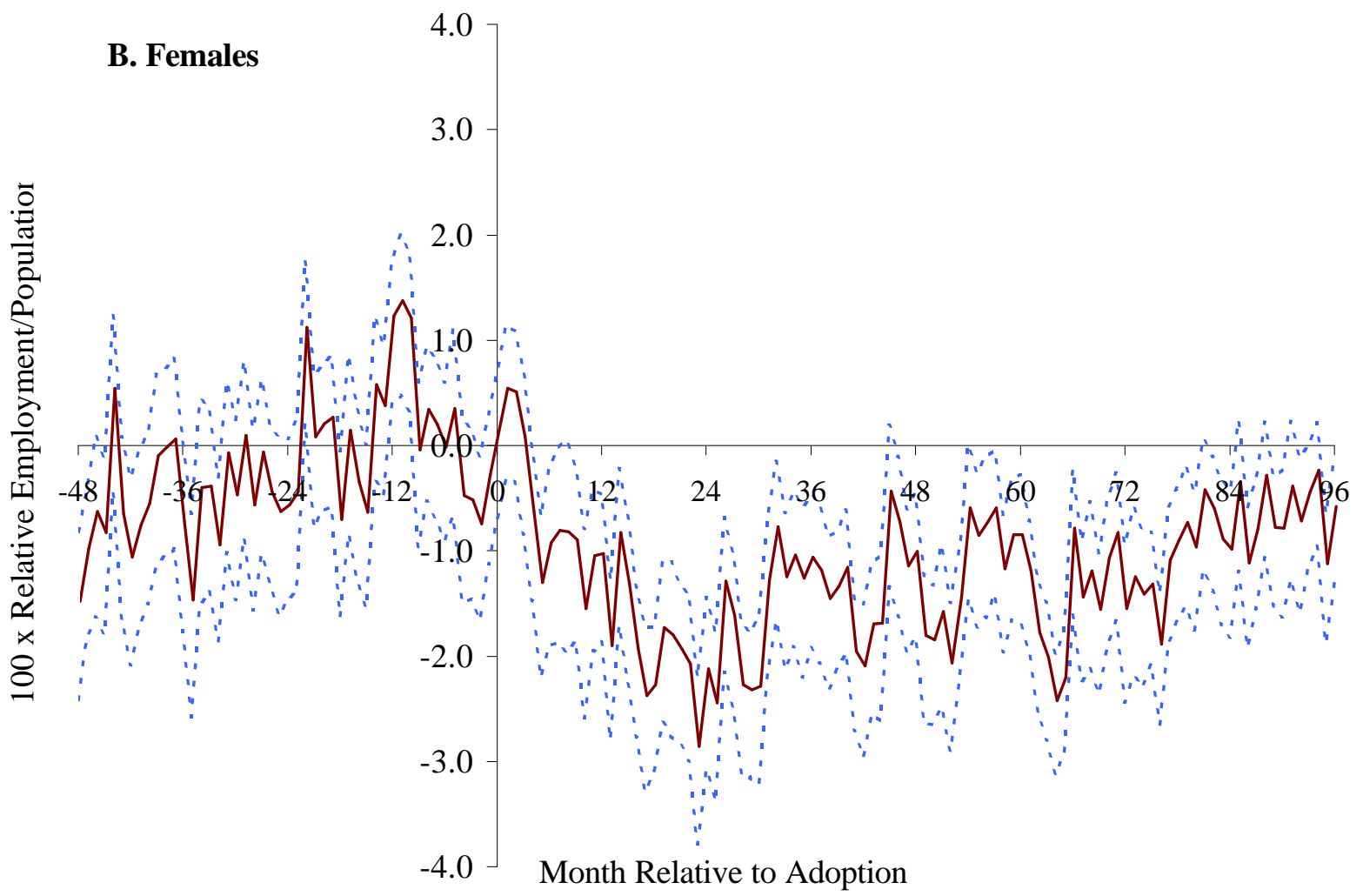

Point Estimate

Robust 90 Percent Confidence Interval

Figure 1. State Employment to Population Rates Pre- and Post- Adoption of Implied Contract Exception: Monthly Leads and Lags 4 Years Prior to 8 Years Post Adoption 

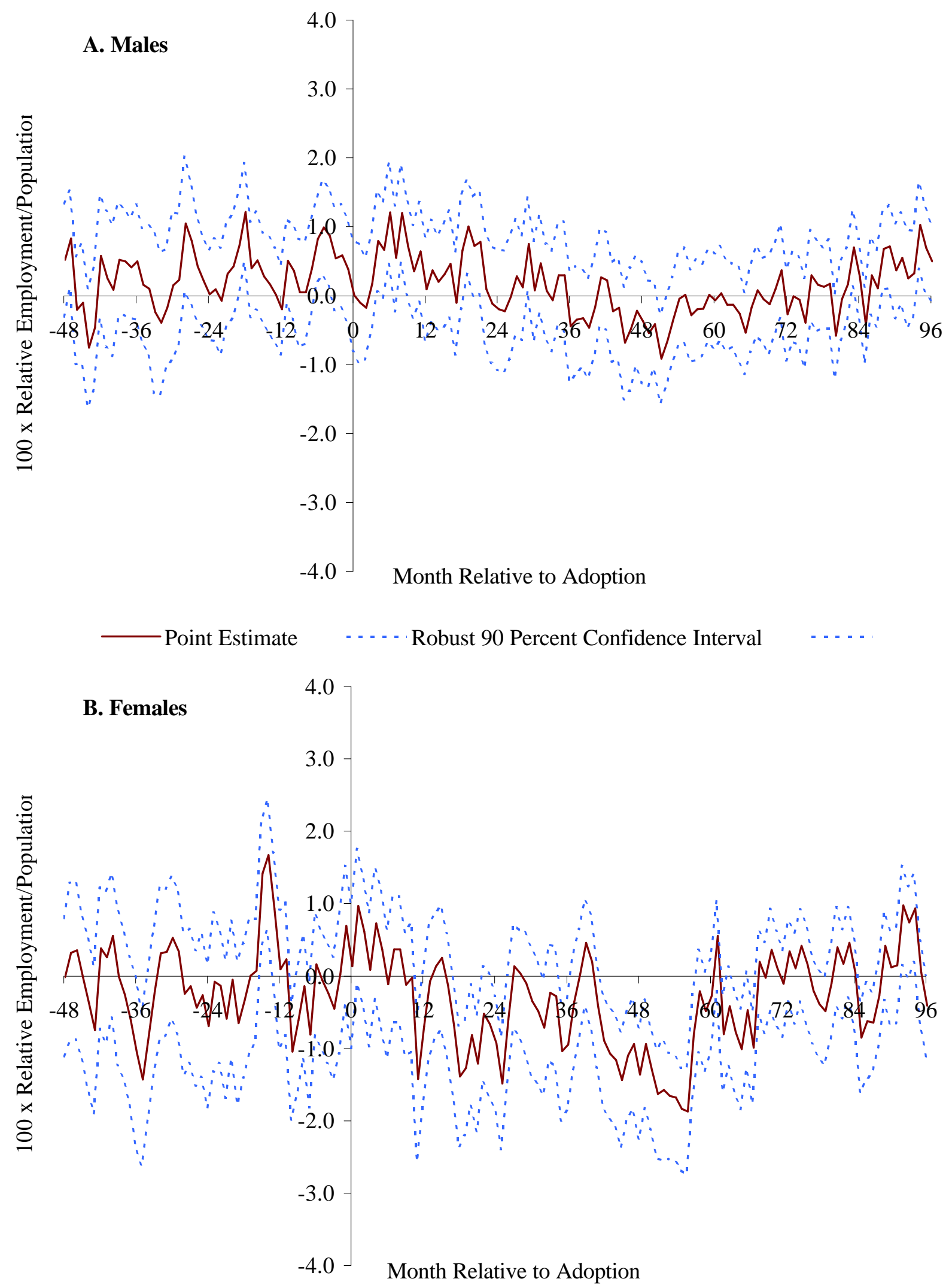

Point Estimate

Robust 90 Percent Confidence Interval

Figure 2. State Employment to Population Rates Pre- and Post- Adoption of Public Policy Exception: Monthly Leads and Lags 4 Years Prior to 8 Years Post Adoption 


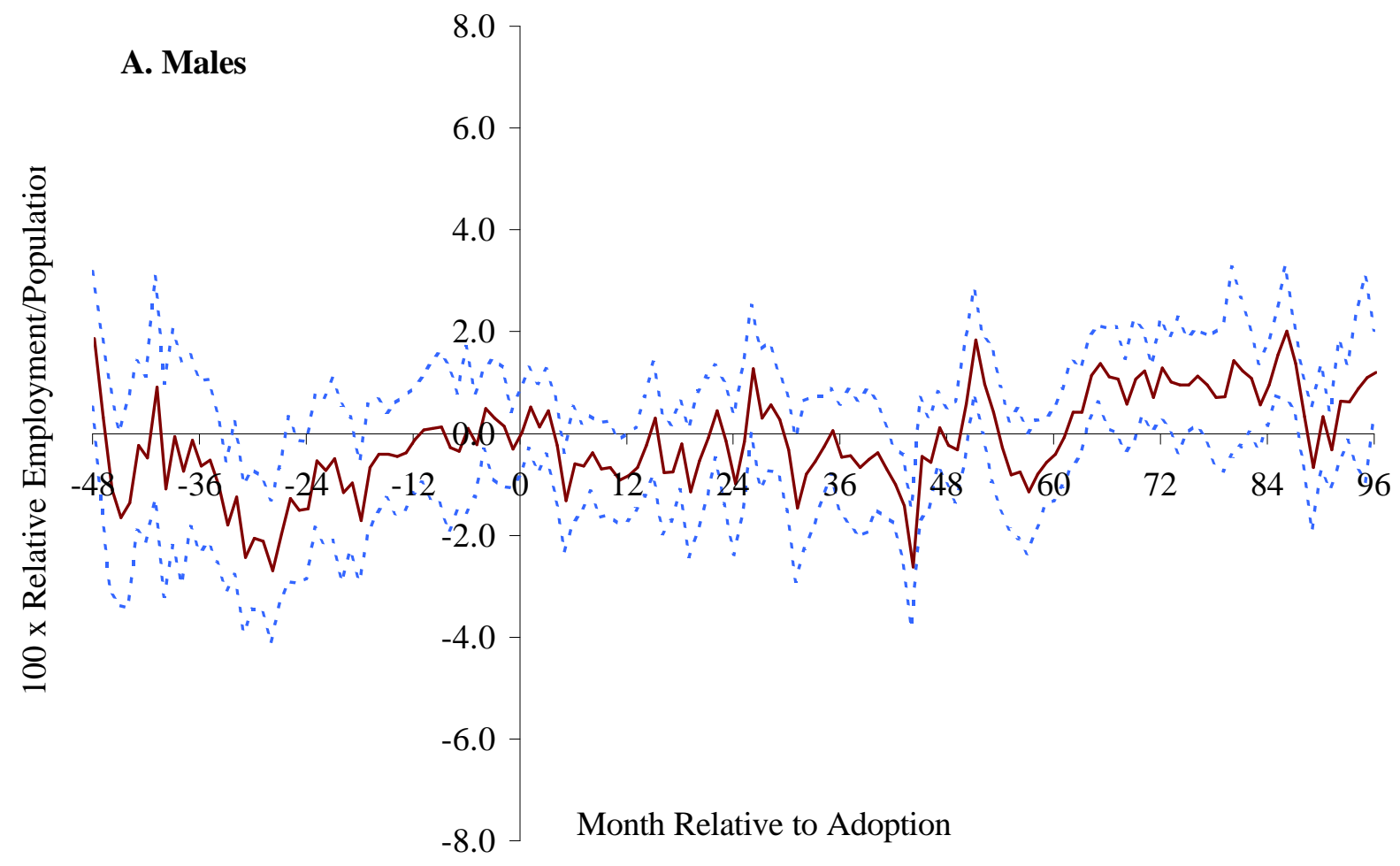

— Point Estimate $\quad$ - - - - Robust 90 Percent Confidence Interval



Point Estimate $\quad$ - - - - Robust 90 Percent Confidence Interval

Figure 3. State Employment to Population Rates Pre- and Post- Adoption of Good Faith Exception: Monthly Leads and Lags 4 Years Prior to 8 Years Post Adoption 


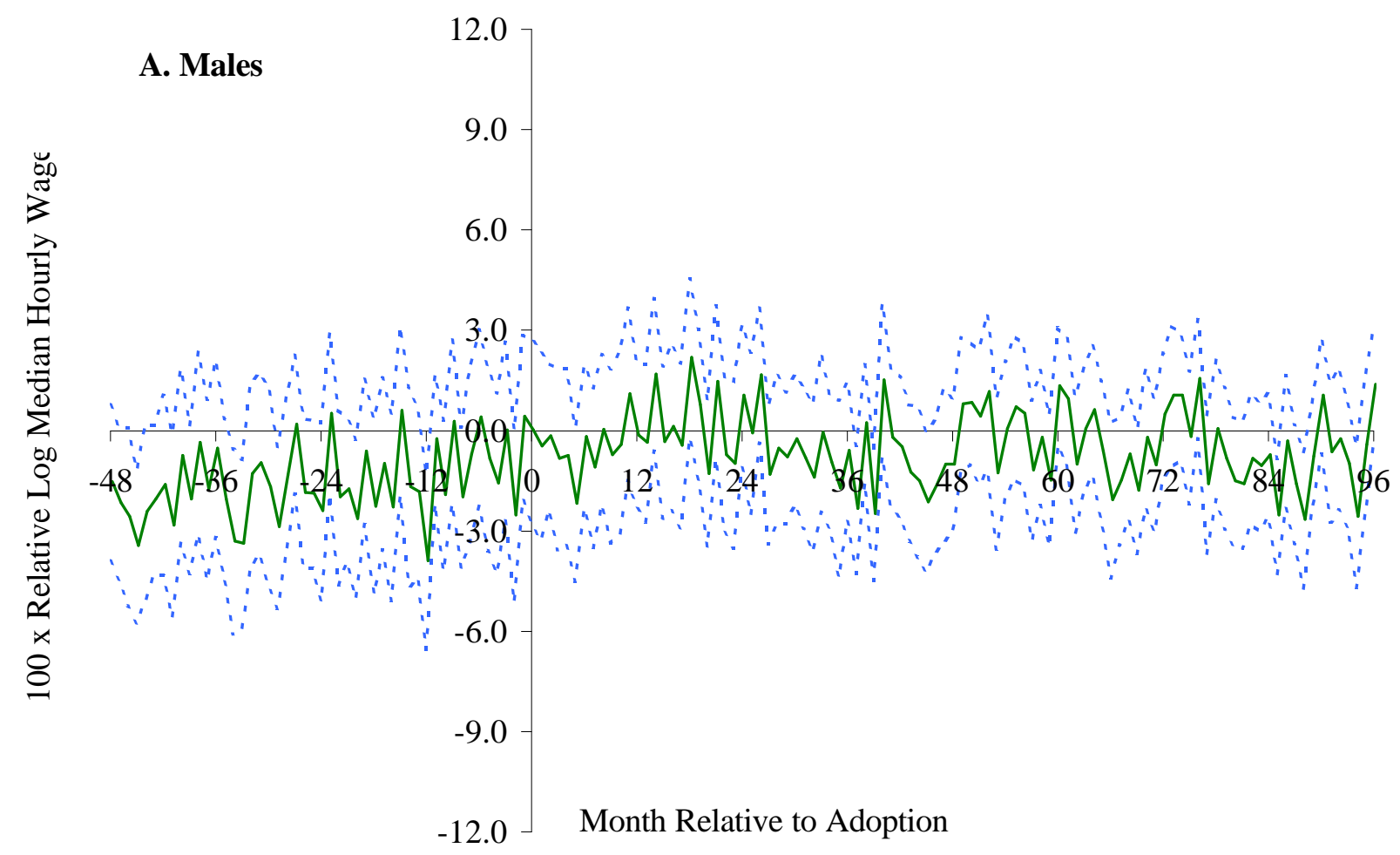

— Point Estimate - - - . Robust 90 Percent Confidence Interval

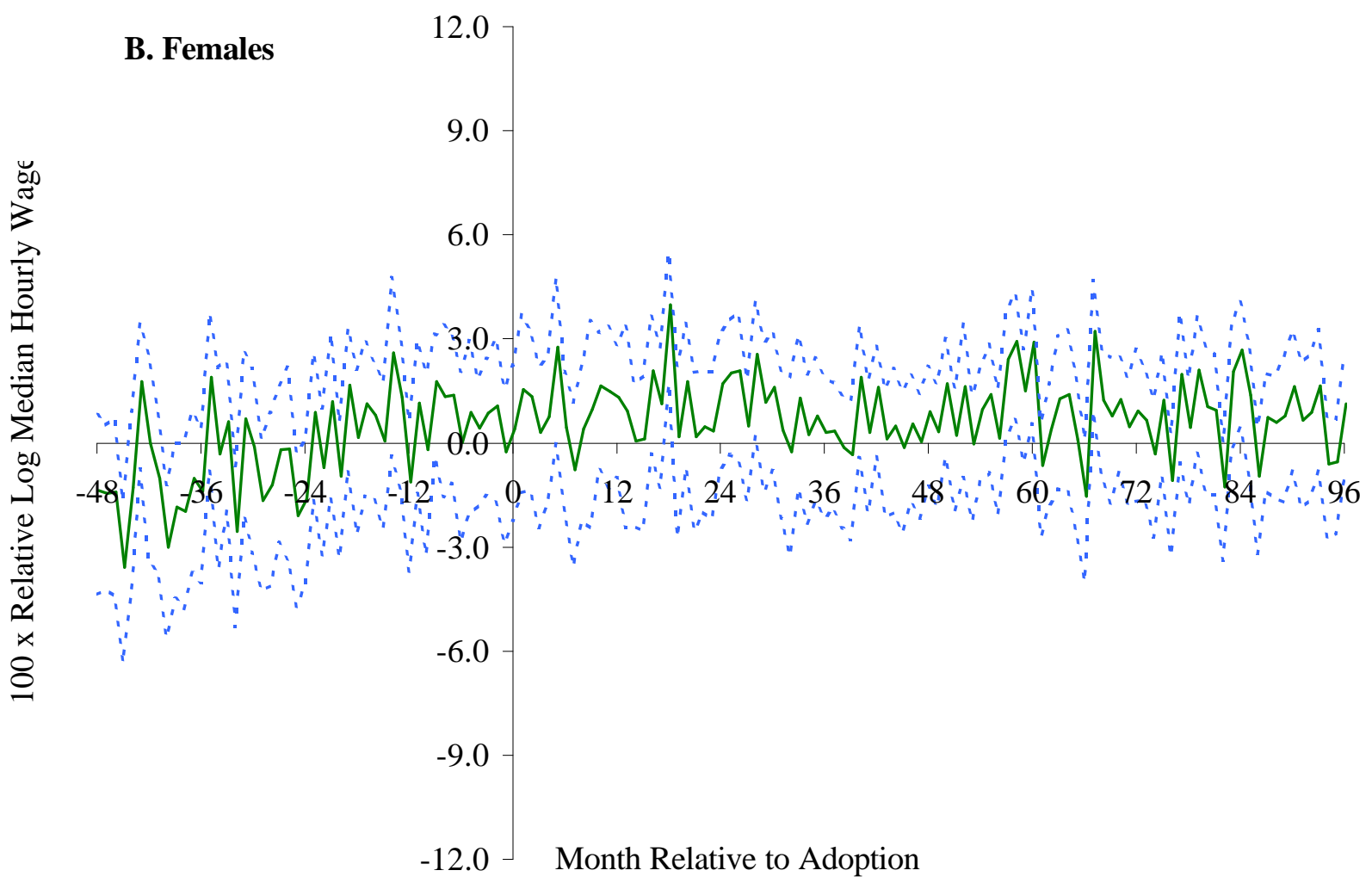

Point Estimate $\quad$ - - - . Robust 90 Percent Confidence Interval

Figure 4. Median Log Full-Time Weekly Wages Pre- and Post- Adoption of Implied Contract Exception: Monthly Leads and Lags 4 Years Prior to 8 Years Post Adoption 

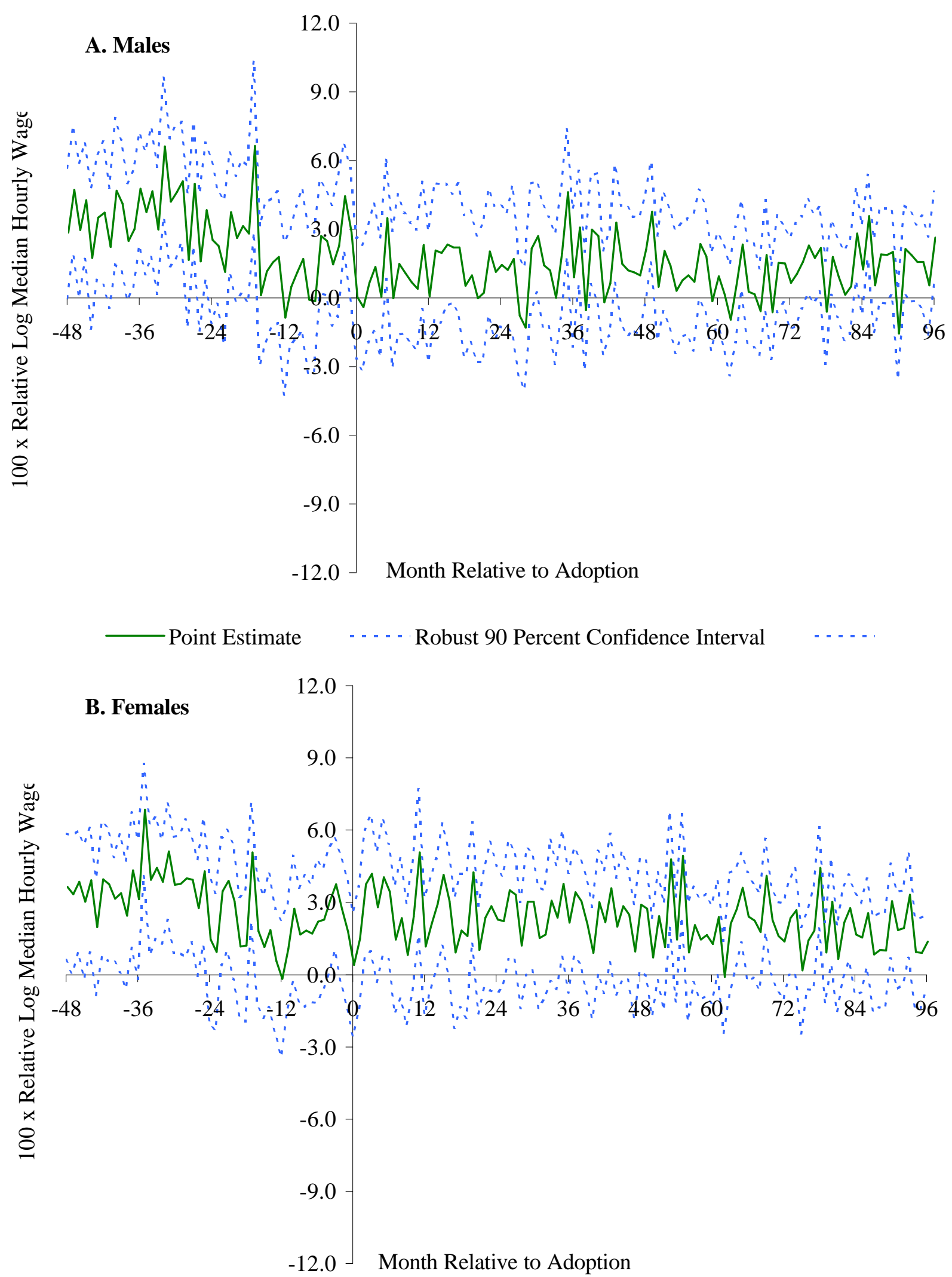

Point Estimate - - - - Robust 90 Percent Confidence Interval

Figure 5. Median Log Full-Time Weekly Wages Pre- and Post- Adoption of Public Policy Exception: Monthly Leads and Lags 4 Years Prior to 8 Years Post Adoption 


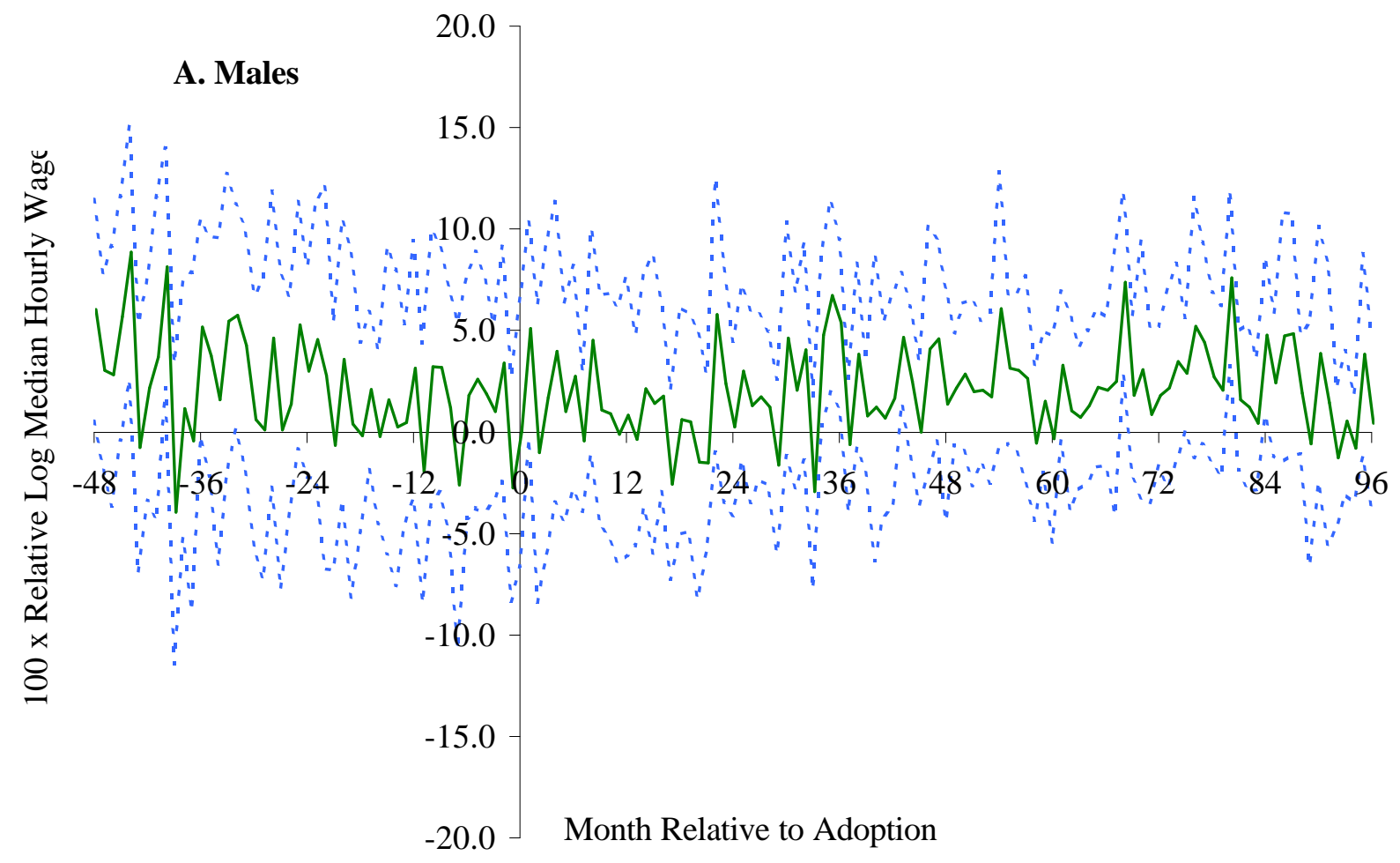

— Point Estimate $\quad$ - - - - Robust 90 Percent Confidence Interval

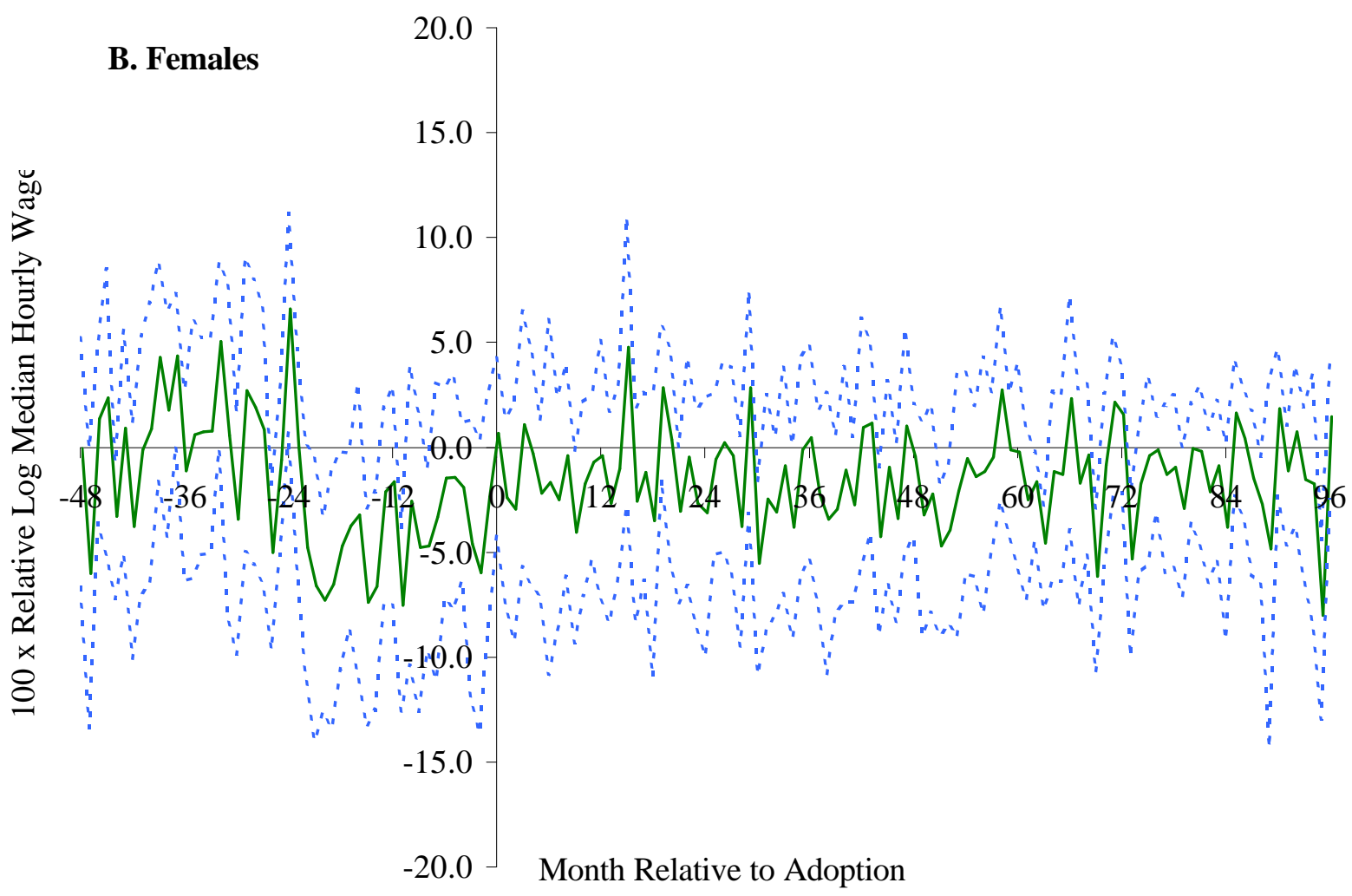

Point Estimate Robust 90 Percent Confidence Interval

Figure 6. Median Log Full-Time Weekly Wages Pre- and Post- Adoption of Good Faith Exception: Monthly Leads and Lags 4 Years Prior to 8 Years Post Adoption 


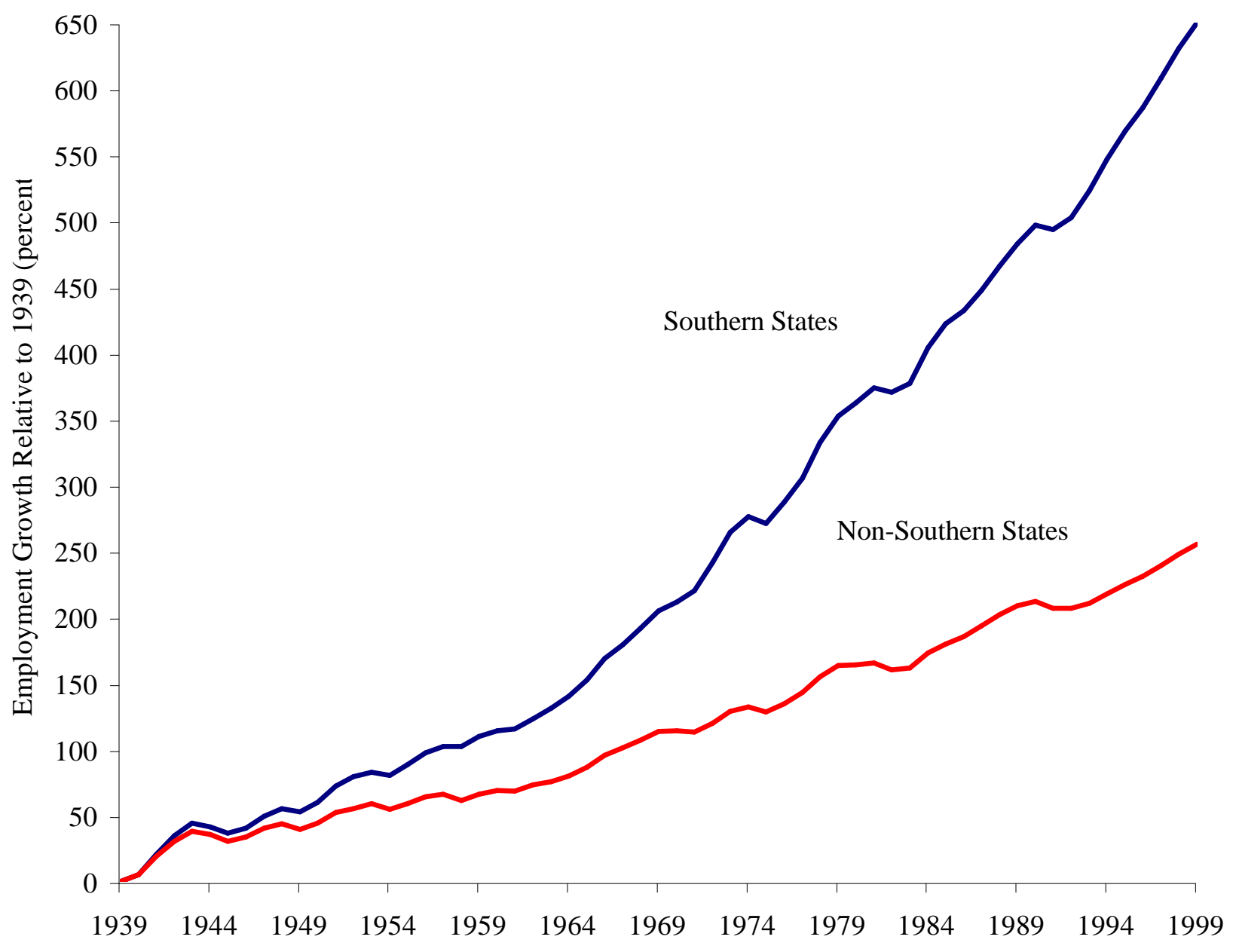

Figure 7. Employment Growth in Southern vs. Non-Southern States, 1939 - 1999 


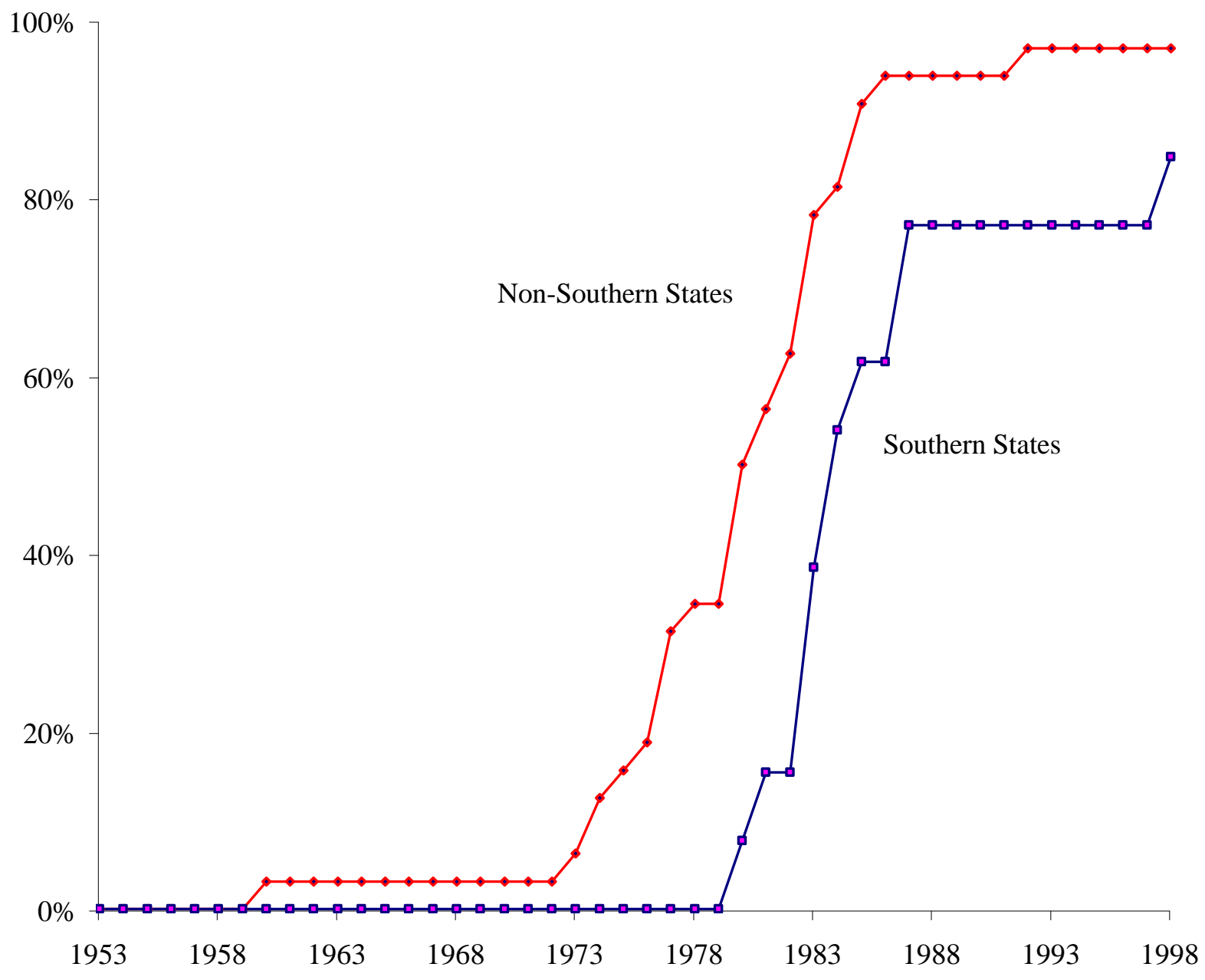

Figure 8. Percent of States Recognizing One or More Wrongful Discharge Laws, 1953 - 1998 


\section{Table 1:}

Difference-in-Difference Estimates of the Impact of Wrongful Discharge Laws on Employment and Earnings for Years 1978 - 1999: Contrasting Outcomes in Years Two and Three Following Adoption of Doctrine to Years One and Two Prior to Adoption

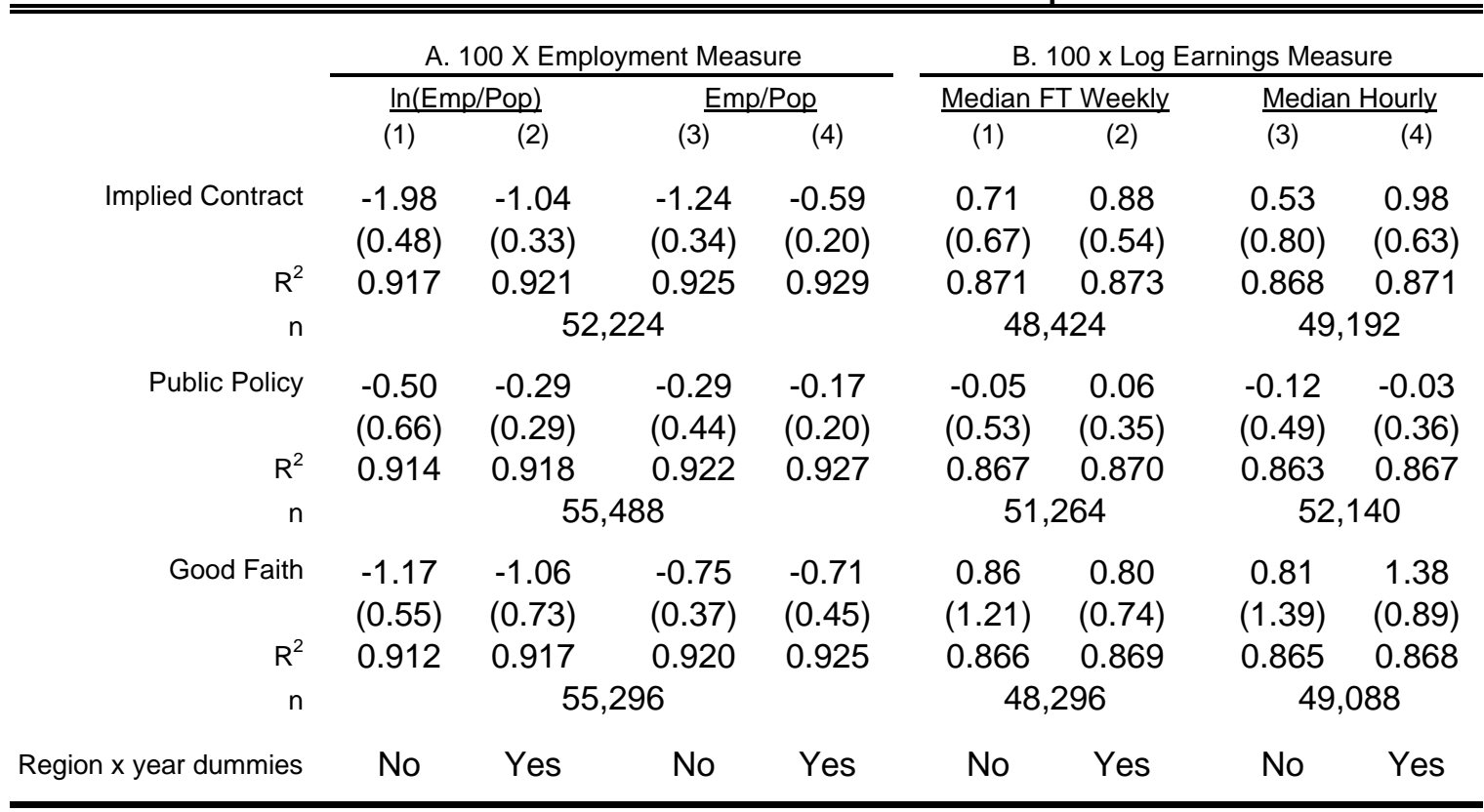

Huber-White robust standard errors in parentheses allow for unrestricted error correlation within states. Each entry is from a separate weighted regression in which the dependent variable is the state-month employment to population ratio (or its log), median log hourly wage or full-time weekly (35+ hours) wage in 50 U.S. states (excluding District of Columbia) for 8 demographic cells: male/female $x$ ages 18-39/ 40-64 x high school or less/ some college or more education. Employment is estimated from complete combined Current Population Survey monthly files for 1978 - 1999. Earnings are estimated from CPS Outgoing Rotation Group samples for 1979 - 1999. All models include state main effects, and indicators for each demographic group in each time period in the sample (in calendar months). Models with region $x$ year dummies also include interactions between 9 Census region dummies ( 1 omitted) and individual calendar year dummies.

Treatment sample includes state-month-demographic group observations for 1 to 24 months prior and 13 36 months following adoption of relevant doctrine in adopting states (months 0 - 12 following adoption are omitted). Control sample includes maximal set of state-month-demographic group employment or earnings observations for corresponding calendar months (rounded to nearest calendar year) for states that did not adopt any of the three doctrines during the relevant pre/post treatment time interval. The coefficient reported is the interaction between treatment status (i.e., adopting a doctrine) and an indicator for $13-36$ months post adoption. Models are weighted by sum of CPS sampling weights in each state $x$ year $x$ month $x$ demographic group cell. In cases where an earnings cell for a state $x$ month $x$ demographic group is empty, the state $x$ demographic group panel is dropped ( 21 years $\times 12$ months $=252$ observations). There are no empty employment cells. 
Table 2:

Difference-in-Difference Estimates of the Impact of Wrongful Discharge Laws on Employment and Earnings for Years 1978 - 1999: Contrasting the Impact of any Doctrine Versus Specific Doctrines

\begin{tabular}{|c|c|c|c|c|c|c|c|c|c|c|c|c|}
\hline & \multicolumn{6}{|c|}{ A. $100 \times \operatorname{In}($ Employment/Population $)$} & \multicolumn{6}{|c|}{ B. $100 \times$ Median Full Time Log Weekly Earnings } \\
\hline & (1) & (2) & (3) & (4) & $(5)$ & (6) & $(1)$ & (2) & (3) & $(4)$ & (5) & (6) \\
\hline Any Doctrine & $\begin{array}{l}-0.97 \\
(0.40)\end{array}$ & $\begin{array}{l}-0.46 \\
(0.21)\end{array}$ & $\begin{array}{c}1.79 \\
(0.52)\end{array}$ & $\begin{array}{c}0.83 \\
(0.53)\end{array}$ & & & $\begin{array}{c}0.39 \\
(0.37)\end{array}$ & $\begin{array}{c}0.62 \\
(0.30)\end{array}$ & $\begin{array}{c}0.88 \\
(1.73)\end{array}$ & $\begin{array}{c}0.88 \\
(0.77)\end{array}$ & & \\
\hline Implied Contract & & & $\begin{array}{l}-3.31 \\
(0.66)\end{array}$ & $\begin{array}{l}-1.55 \\
(0.59)\end{array}$ & $\begin{array}{c}-1.70 \\
(0.47)\end{array}$ & $\begin{array}{c}-0.80 \\
(0.29)\end{array}$ & & & $\begin{array}{c}-0.59 \\
(1.51)\end{array}$ & $\begin{array}{c}-0.23 \\
(0.79)\end{array}$ & $\begin{array}{c}0.31 \\
(0.43)\end{array}$ & $\begin{array}{c}0.59 \\
(0.41)\end{array}$ \\
\hline Public Policy & & & $\begin{array}{c}-1.92 \\
(0.62)\end{array}$ & $\begin{array}{c}-1.04 \\
(0.51)\end{array}$ & $\begin{array}{l}-0.41 \\
(0.58)\end{array}$ & $\begin{array}{c}-0.31 \\
(0.27)\end{array}$ & & & $\begin{array}{l}-0.97 \\
(1.59)\end{array}$ & $\begin{array}{c}-0.59 \\
(0.73)\end{array}$ & $\begin{array}{c}-0.52 \\
(0.50)\end{array}$ & $\begin{array}{c}0.07 \\
(0.42)\end{array}$ \\
\hline Good Faith & & & $\begin{array}{l}-2.78 \\
(0.68)\end{array}$ & $\begin{array}{c}-0.89 \\
(0.65)\end{array}$ & $\begin{array}{l}-1.30 \\
(0.41)\end{array}$ & $\begin{array}{c}-0.24 \\
(0.60)\end{array}$ & & & $\begin{array}{c}0.44 \\
(1.70)\end{array}$ & $\begin{array}{c}0.84 \\
(1.00)\end{array}$ & $\begin{array}{c}1.10 \\
(0.96)\end{array}$ & $\begin{array}{c}1.48 \\
(0.76)\end{array}$ \\
\hline $\begin{array}{r}\mathrm{R}^{2} \\
\mathrm{n}\end{array}$ & 0.910 & 0.915 & $\begin{array}{r}0.910 \\
76\end{array}$ & $\begin{array}{l}0.915 \\
832\end{array}$ & 0.910 & 0.924 & 0.860 & 0.866 & $\begin{array}{r}0.860 \\
72\end{array}$ & $\begin{array}{c}0.862 \\
166\end{array}$ & 0.860 & 0.866 \\
\hline Region $x$ year dummies & No & Yes & No & Yes & No & Yes & No & Yes & No & Yes & No & Yes \\
\hline
\end{tabular}

Huber-White robust standard errors in parentheses allow for unrestricted error correlation within states. Dependent variables, samples, and weights are as in Table 1. The coefficients reported are the interactions between treatment status (i.e., adopting any doctrine or a specific doctrine) and an indicator for 13 - 36 months post adoption. 
Table 3:

Difference-in-Difference Estimates of the Impact of Wrongful Discharge Laws on Median Log Hourly Earnings of Males: Contrasting Estimates Excluding and Including Non-Employed.

\begin{tabular}{|c|c|c|c|c|c|c|c|c|c|c|c|c|}
\hline & \multicolumn{6}{|c|}{$\begin{array}{c}\text { A. } 100 \times \text { Median Log Hourly Wage: } \\
\text { Employed Males Only }\end{array}$} & \multicolumn{6}{|c|}{$\begin{array}{l}\text { B. } 100 \text { x Median Log Hourly Wage: } \\
\text { All Males }\end{array}$} \\
\hline & (1) & (2) & (3) & (4) & (5) & (6) & (1) & (2) & (3) & (4) & (5) & (6) \\
\hline Any Doctrine & $\begin{array}{c}0.35 \\
(0.53)\end{array}$ & $\begin{array}{l}1.32 \\
(0.43)\end{array}$ & $\begin{array}{c}0.69 \\
(1.46)\end{array}$ & $\begin{array}{c}1.86 \\
(1.32)\end{array}$ & & & $\begin{array}{l}-0.86 \\
(0.85)\end{array}$ & $\begin{array}{c}1.11 \\
(0.60)\end{array}$ & $\begin{array}{c}1.87 \\
(1.35)\end{array}$ & $\begin{array}{c}2.54 \\
(1.27)\end{array}$ & & \\
\hline Implied Contract & & & $\begin{array}{l}-0.46 \\
(1.35)\end{array}$ & $\begin{array}{l}-0.16 \\
(1.45)\end{array}$ & $\begin{array}{l}0.20 \\
(0.74)\end{array}$ & $\begin{array}{c}1.53 \\
(0.68)\end{array}$ & & & $\begin{array}{l}-3.85 \\
(1.71)\end{array}$ & $\begin{array}{l}-1.63 \\
(1.26)\end{array}$ & $\begin{array}{l}-2.14 \\
(1.33)\end{array}$ & $\begin{array}{c}0.70 \\
(0.92)\end{array}$ \\
\hline Public Policy & & & $\begin{array}{l}-0.59 \\
(1.24)\end{array}$ & $\begin{array}{l}-1.00 \\
(1.35)\end{array}$ & $\begin{array}{l}-0.29 \\
(0.74)\end{array}$ & $\begin{array}{c}0.53 \\
(0.58)\end{array}$ & & & $\begin{array}{l}-1.39 \\
(1.59)\end{array}$ & $\begin{array}{l}-0.99 \\
(1.59)\end{array}$ & $\begin{array}{l}-0.04 \\
(1.19)\end{array}$ & $\begin{array}{l}1.16 \\
(0.76)\end{array}$ \\
\hline Good Faith & & & $\begin{array}{l}-0.20 \\
(1.80)\end{array}$ & $\begin{array}{l}-1.13 \\
(2.22)\end{array}$ & $\begin{array}{c}0.40 \\
(1.52)\end{array}$ & $\begin{array}{c}0.52 \\
(1.87)\end{array}$ & & & $\begin{array}{l}-2.94 \\
(1.82)\end{array}$ & $\begin{array}{l}-1.54 \\
(1.80)\end{array}$ & $\begin{array}{l}-1.27 \\
(1.76)\end{array}$ & $\begin{array}{c}0.71 \\
(1.64)\end{array}$ \\
\hline $\begin{array}{r}R^{2} \\
n\end{array}$ & 0.855 & 0.865 & $\begin{array}{r}0.855 \\
21\end{array}$ & $\begin{array}{l}0.865 \\
534\end{array}$ & 0.855 & 0.865 & 0.820 & 0.831 & $\begin{array}{r}0.820 \\
21\end{array}$ & $\begin{array}{l}0.831 \\
.534\end{array}$ & 0.820 & 0.831 \\
\hline Region $\mathrm{x}$ year dummies & No & Yes & No & Yes & No & Yes & No & Yes & No & Yes & No & Yes \\
\hline
\end{tabular}

Huber-White robust standard errors in parentheses allow for unrestricted error correlation within states. Samples, specifications and weights are as in Table 2. Medians in Panel A are calculated only for employed males. Those in Panel $\mathrm{B}$ are calculated for all males within the relevant demographic categories; those with zero earnings are assumed to fall below the median. In state-year-month-demographic group cells where more than 50 percent of potential workers are not employed, the state-demographic panel for that group is dropped (21 years $\times 12$ months) in both Panel A and Panel B of the table. 
Table 4:

Difference-in-Difference Estimates of the Impact of Wrongful Discharge Laws on Employment to Population Rates: Estimates by Adopter Cohorts

\begin{tabular}{|c|c|c|c|}
\hline & \multicolumn{3}{|c|}{ Dependent Variable: $100 \times \ln ($ Employment/Population $)$} \\
\hline & Implied Contract & Public Policy & \multirow{2}{*}{$\frac{\text { Good Faith }}{(1)}$} \\
\hline & $\begin{array}{ll}(1) & (2)\end{array}$ & (2) & \\
\hline $1980-1983$ & $\begin{array}{cc}-1.92 & -0.51 \\
(0.52) & (0.18)\end{array}$ & $\begin{array}{cc}-0.40 & 0.35 \\
(0.63) & (0.44)\end{array}$ & $\begin{array}{ll}-1.31 & -0.87 \\
(0.61) & (0.39)\end{array}$ \\
\hline $\mathrm{R}^{2}$ & 0.9310 .932 & 0.9320 .933 & 0.9380 .939 \\
\hline$n$ & 21,408 & 19,872 & 17,184 \\
\hline States adopting & 15 & 11 & 6 \\
\hline $1984-1987$ & $\begin{array}{cc}-1.69 & -0.75 \\
(0.88) & (0.44)\end{array}$ & $\begin{array}{ll}-1.40 & -0.18 \\
(0.85) & (0.33)\end{array}$ & $\begin{array}{cc}-3.08 & 2.25 \\
(0.71) & (1.14)\end{array}$ \\
\hline$R^{2}$ & $0.928 \quad 0.930$ & 0.9290 .931 & 0.9340 .936 \\
\hline$n$ & 19,104 & 18,720 & 11,904 \\
\hline States adopting & 18 & 17 & 3 \\
\hline $1988-1992$ & $\begin{array}{cc}-1.92 & -0.09 \\
(1.00) & (0.83)\end{array}$ & $\begin{array}{cc}2.33 & 0.12 \\
(0.67) & (0.44)\end{array}$ & $\begin{array}{cc}1.61 & 0.88 \\
(0.38) & (0.73)\end{array}$ \\
\hline$R^{2}$ & 0.9050 .909 & 0.9010 .905 & 0.9010 .905 \\
\hline$n$ & 22,176 & 27,840 & 19,680 \\
\hline States adopting & 10 & 0 & 2 \\
\hline $1993-1998$ & $\mathrm{n} / \mathrm{a}$ & $\mathrm{n} / \mathrm{a}$ & $\begin{array}{cc}0.49 & -0.13 \\
(0.15) & (0.60)\end{array}$ \\
\hline$R^{2}$ & & & 0.8850 .886 \\
\hline $\mathrm{n}$ & & & 17,856 \\
\hline States adopting & 0 & 0 & 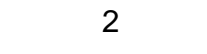 \\
\hline $\begin{array}{r}\text { Region } \mathrm{x} \text { year } \\
\text { dummies }\end{array}$ & Yes & Yes & Yes \\
\hline
\end{tabular}

Huber-White robust standard errors in parentheses allow for unrestricted error correlation among contiguous time periods within each state. Dependent variables, specifications, and weights are identical to Table 2. 
Table 5:

Difference-in-Difference Estimates of the Impact of Wrongful Discharge Laws on Log Employment to Population Rates for Years 1978 1999: Testing Sensitivity to Selection of Pre- and Post- Adoption Treatment Periods.

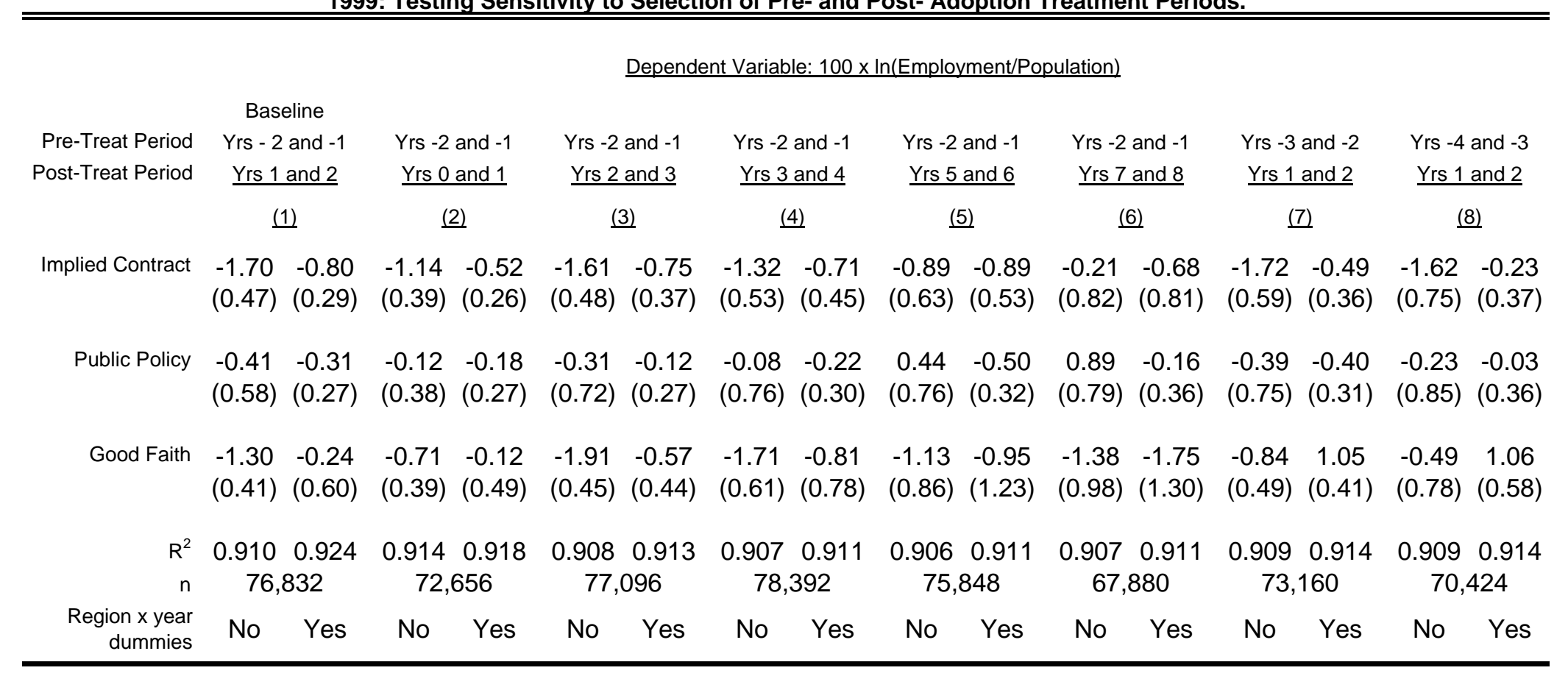

Huber-White robust standard errors in parentheses allow for unrestricted error correlation within states. Samples, specifications and weights are identical to Table 3 except, as noted, the selection of pre- and post- treatment intervals for law adoption. 


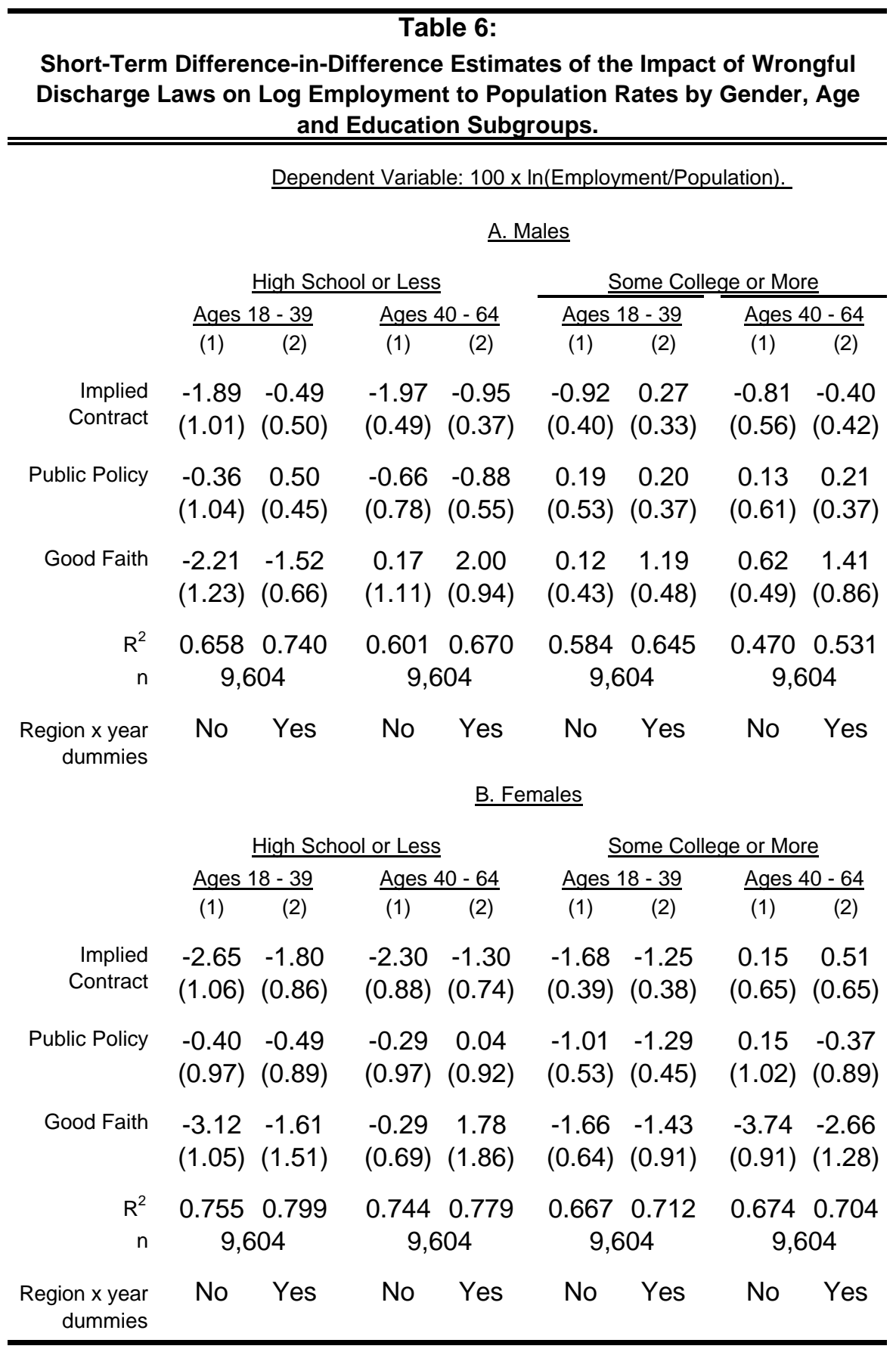

Huber-White robust standard errors in parentheses allow for unrestricted error correlation within each state. Separate regressions in each column contrast employment of the specified demographic group in years one and two following adoption of a doctrine relative to years two and one prior to adoption of the doctrine. Samples, specifications, and weights are identical to Table 2. 


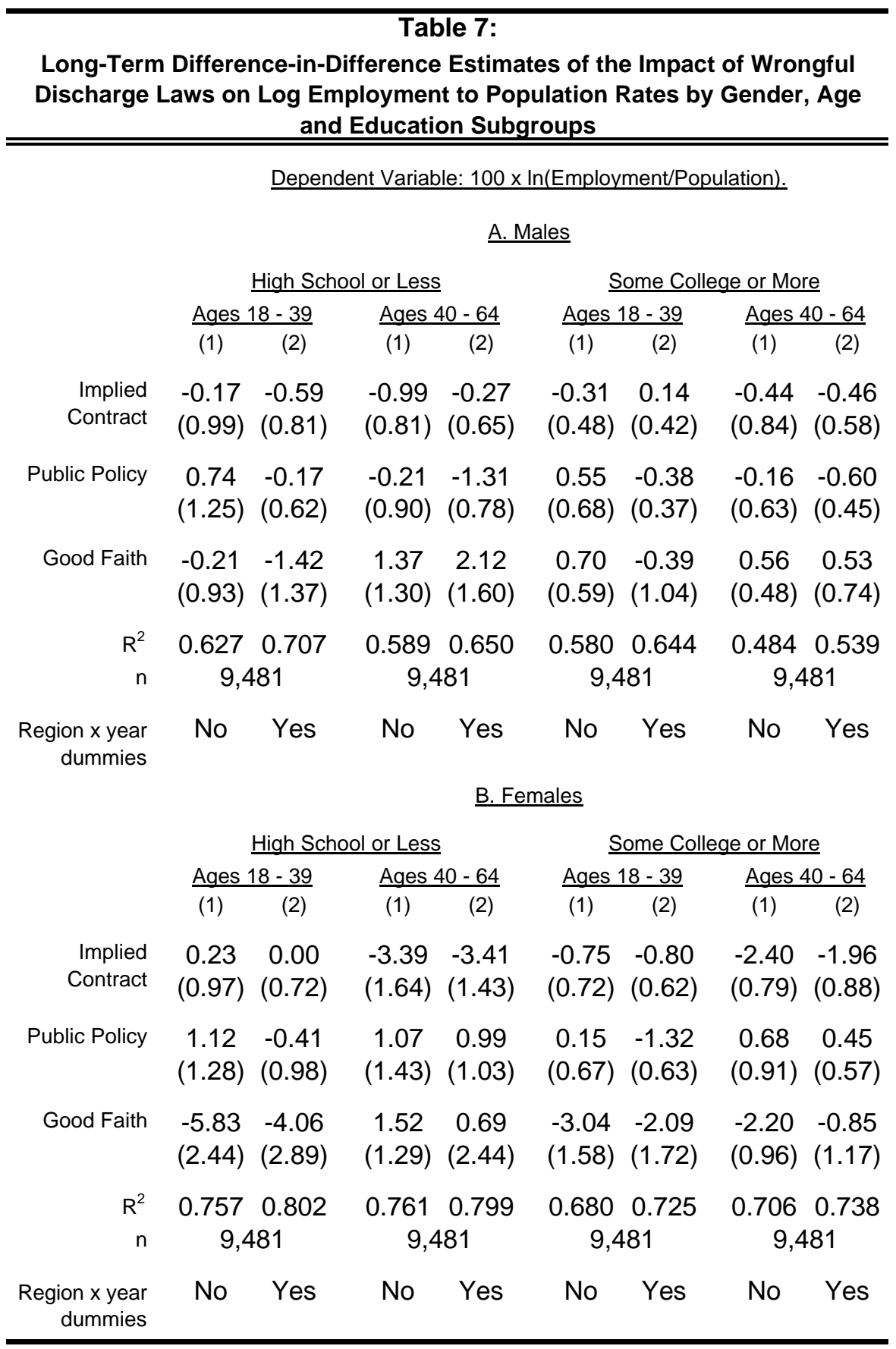

Huber-White robust standard errors in parentheses allow for unrestricted error correlation within each state. Separate regressions in each column contrast employment of the specified demographic group in years five and six following adoption of a doctrine relative to years two and one prior to adoption of the doctrine. 
Table 8:

Replication of Dertouzos \& Karoly, 1993, The Estimated Impact of Wrongful Discharge Laws on Log State Employment, 1980 - 1987.

\begin{tabular}{|c|c|c|c|c|c|c|c|c|}
\hline & \multicolumn{8}{|c|}{ Dependent Variable: $100 \times$ Log State Employment } \\
\hline & \multicolumn{4}{|c|}{$\begin{array}{l}\text { A. Replication of D-K's Instrumental } \\
\text { Variables Estimates }\end{array}$} & \multicolumn{4}{|c|}{$\begin{array}{l}\text { B. Replication of D-K using a } \\
\text { Difference-in-Difference Estimator }\end{array}$} \\
\hline & (1) & (2) & (3) & (4) & (1) & (2) & (3) & (4) \\
\hline $\begin{array}{l}\text { Implied Contract or Good } \\
\text { Faith (Contract) Doctrine }\end{array}$ & $\begin{array}{l}-4.44 \\
(1.26)\end{array}$ & $\begin{array}{l}-1.45 \\
(0.94)\end{array}$ & $\begin{array}{l}-14.53 \\
(2.39)\end{array}$ & $\begin{array}{l}-1.13 \\
(1.70)\end{array}$ & $\begin{array}{l}0.97 \\
(0.44)\end{array}$ & $\begin{array}{l}-0.75 \\
(0.36)\end{array}$ & $\begin{array}{l}-0.42 \\
(0.91)\end{array}$ & $\begin{array}{l}-1.46 \\
(0.67)\end{array}$ \\
\hline $\begin{array}{l}\text { Broad Public Policy or } \\
\text { Good Faith (Tort) Doctrine }\end{array}$ & $\begin{array}{l}-3.00 \\
(1.50)\end{array}$ & $\begin{array}{l}-1.26 \\
(1.58)\end{array}$ & $\begin{array}{l}3.48 \\
(2.91)\end{array}$ & $\begin{array}{l}-5.83 \\
(2.86)\end{array}$ & $\begin{array}{l}-1.13 \\
(0.60)\end{array}$ & $\begin{array}{c}0.46 \\
(0.58)\end{array}$ & $\begin{array}{l}-0.15 \\
(1.22)\end{array}$ & $\begin{array}{c}0.00 \\
(1.05)\end{array}$ \\
\hline $\begin{array}{r}\text { Narrow Public Policy } \\
\text { Doctrine }\end{array}$ & $\begin{array}{c}0.03 \\
(0.94)\end{array}$ & $\begin{array}{l}-0.55 \\
(0.96)\end{array}$ & $\begin{array}{l}-5.19 \\
(1.82)\end{array}$ & $\begin{array}{c}0.05 \\
(1.73)\end{array}$ & $\begin{array}{c}0.16 \\
(0.40)\end{array}$ & $\begin{array}{l}0.43 \\
(0.32)\end{array}$ & $\begin{array}{c}0.27 \\
(0.74)\end{array}$ & $\begin{array}{l}-0.73 \\
(0.56)\end{array}$ \\
\hline $\begin{array}{r}100 \times \log (\text { Gross State } \\
\text { Product) }\end{array}$ & $\begin{array}{c}0.73 \\
(0.02)\end{array}$ & $\begin{array}{c}0.77 \\
(0.03)\end{array}$ & & & $\begin{array}{c}0.76 \\
(0.02)\end{array}$ & $\begin{array}{c}0.77 \\
(0.03)\end{array}$ & & \\
\hline $\begin{array}{r}100 \times \Delta \log (\text { Gross State } \\
\text { Product) }\end{array}$ & $\begin{array}{l}-0.42 \\
(0.04)\end{array}$ & $\begin{array}{l}-0.40 \\
(0.03)\end{array}$ & & & $\begin{array}{l}-0.42 \\
(0.04)\end{array}$ & $\begin{array}{l}-0.40 \\
(0.03)\end{array}$ & & \\
\hline $\begin{array}{r}\text { State-Specific Time } \\
\text { Trends included in model }\end{array}$ & No & Yes & No & Yes & No & Yes & No & Yes \\
\hline $\begin{array}{l}\text { F-Test of significance of } \\
\text { state-specific time trends }\end{array}$ & & 0.00 & & 0.00 & & 0.00 & & 0.00 \\
\hline $\mathrm{R}^{2}$ & 0.9997 & 0.9999 & 0.9989 & 0.9999 & 0.9997 & 0.9999 & 0.9987 & 0.9997 \\
\hline
\end{tabular}

$n=400$ (50 states $\times 8$ years). Column (1) tabulates authors' replication of Dertouzas and Karoly (1993), Table 8-4, column (2), an instrumental variables estimate of the impact of exceptions to employment at will on log state employment. Columns (2) - (4) test the sensitivity of the D\&K findings to minor specification checks. Columns (5) - (8) estimate these models using a difference-in-difference estimator. Following D\&K, estimates are unweighted, and OLS standard errors are not adjusted for instrumentation of employment at will exceptions. Instruments include: whether a state has a right to work statute, whether a state has a republican governor, the percentage change in lawyers per capita, the percentage of neighboring states recognizing each doctrine and the square of this measure, the percentage unionized, the change in percentage unionized, and the change in the percentage unemployment. 
Table 9:

Robustness Tests of the Impact of State Common Law Exceptions on Employment to Population:

Using Legal Classifications of Autor, Donohue Scwab, Morriss, Dertouzos and Karoly, Walsh and Schwarz, and Walsh and Schwarz Corrected.

Dependent Variable: $100 \times \ln ($ Employment/Population)

\begin{tabular}{|c|c|c|c|c|c|c|c|c|c|c|c|c|c|c|c|c|}
\hline & \multicolumn{2}{|c|}{$\begin{array}{l}\text { A. Baseline: ADS } \\
1978-1999 \\
\end{array}$} & \multicolumn{4}{|c|}{$\begin{array}{l}\text { B. Comparison with Morriss, } \\
\text { Years: } 1978-1989\end{array}$} & \multicolumn{4}{|c|}{$\begin{array}{l}\text { C. Comparison with D\&K, } \\
\text { Years: } 1980-1987\end{array}$} & \multicolumn{6}{|c|}{$\begin{array}{c}\text { D. Comparison with Walsh \& Schwarz, } \\
\text { Years: } 1978-1994\end{array}$} \\
\hline & & & \multicolumn{2}{|c|}{ ADS } & \multicolumn{2}{|c|}{ Morriss, 1995} & \multicolumn{2}{|c|}{ ADS } & \multicolumn{2}{|c|}{ D\&K, 1992} & \multicolumn{2}{|c|}{ ADS } & \multicolumn{2}{|c|}{ W\&S } & \multicolumn{2}{|c|}{ W\&S Corrected } \\
\hline & (1) & (2) & (1) & (2) & (3) & (4) & (1) & (2) & (3) & (4) & (1) & (2) & (3) & (4) & (5) & (6) \\
\hline Implied Contract & $\begin{array}{l}-0.59 \\
(0.30)\end{array}$ & $\begin{array}{c}-0.92 \\
(0.33)\end{array}$ & $\begin{array}{l}-0.95 \\
(0.30)\end{array}$ & $\begin{array}{l}-1.18 \\
(0.37)\end{array}$ & $\begin{array}{c}-0.92 \\
(0.30)\end{array}$ & $\begin{array}{l}-1.27 \\
(0.38)\end{array}$ & $\begin{array}{c}-1.08 \\
(0.35)\end{array}$ & $\begin{array}{c}-1.33 \\
(0.42)\end{array}$ & $\begin{array}{c}0.04 \\
(0.29)\end{array}$ & $\begin{array}{c}-0.68 \\
(0.38)\end{array}$ & $\begin{array}{c}-0.58 \\
(0.30)\end{array}$ & $\begin{array}{c}-1.34 \\
(0.34)\end{array}$ & $\begin{array}{c}0.41 \\
(0.29)\end{array}$ & $\begin{array}{c}0.10 \\
(0.32)\end{array}$ & $\begin{array}{l}-0.11 \\
(0.30)\end{array}$ & $\begin{array}{l}-0.86 \\
(0.37)\end{array}$ \\
\hline Public Policy & $\begin{array}{c}0.45 \\
(0.28)\end{array}$ & $\begin{array}{c}0.36 \\
(0.31)\end{array}$ & $\begin{array}{c}-0.31 \\
(0.29)\end{array}$ & $\begin{array}{l}-0.26 \\
(0.30)\end{array}$ & $\begin{array}{c}-0.33 \\
(0.29)\end{array}$ & $\begin{array}{l}-0.28 \\
(0.29)\end{array}$ & $\begin{array}{l}-0.40 \\
(0.37)\end{array}$ & $\begin{array}{l}-0.55 \\
(0.37)\end{array}$ & $\begin{array}{l}-0.51 \\
(0.42)\end{array}$ & $\begin{array}{l}-0.30 \\
(0.42)\end{array}$ & $\begin{array}{c}0.40 \\
(0.29)\end{array}$ & $\begin{array}{c}-0.18 \\
(0.30)\end{array}$ & $\begin{array}{c}0.38 \\
(0.32)\end{array}$ & $\begin{array}{l}-0.25 \\
(0.31)\end{array}$ & $\begin{array}{c}0.38 \\
(0.30)\end{array}$ & $\begin{array}{c}0.25 \\
(0.32)\end{array}$ \\
\hline Good Faith & $\begin{array}{l}-1.88 \\
(0.54)\end{array}$ & $\begin{array}{c}0.29 \\
(0.41)\end{array}$ & $\begin{array}{l}-1.23 \\
(0.35)\end{array}$ & $\begin{array}{l}-0.67 \\
(0.43)\end{array}$ & $\begin{array}{c}-0.97 \\
(0.36)\end{array}$ & $\begin{array}{l}-0.35 \\
(0.39)\end{array}$ & $\begin{array}{l}-1.35 \\
(0.34)\end{array}$ & $\begin{array}{l}-0.58 \\
(0.42)\end{array}$ & $\begin{array}{c}-0.76 \\
(0.35)\end{array}$ & $\begin{array}{l}-0.39 \\
(0.38)\end{array}$ & $\begin{array}{l}-1.68 \\
(0.49)\end{array}$ & $\begin{array}{c}0.69 \\
(0.42)\end{array}$ & $\begin{array}{l}-1.09 \\
(0.57)\end{array}$ & $\begin{array}{c}0.91 \\
(0.48)\end{array}$ & $\begin{array}{l}-1.18 \\
(0.49)\end{array}$ & $\begin{array}{c}1.22 \\
(0.46)\end{array}$ \\
\hline $\begin{array}{l}\text { State \& Demographic } \\
\text { Group Time Trends }\end{array}$ & No & Yes & No & Yes & No & Yes & No & Yes & No & Yes & No & Yes & No & Yes & No & Yes \\
\hline $\mathrm{R}^{2}$ & 0.91 & 0.94 & 0.94 & 0.95 & 0.94 & 0.95 & 0.95 & 0.96 & 0.95 & 0.96 & 0.92 & 0.95 & 0.92 & 0.95 & 0.92 & 0.95 \\
\hline$n$ & 8,8 & 300 & & & & & & & & & & & & 0 & & \\
\hline
\end{tabular}

Huber-White robust standard errors in parentheses allow for clustering of errors across demographic group observations within states by year. Eight demographic groups are used in each state-year (male/female x high school or less/some college or more x ages 18-39/40-64). State, year, and demographic group main effects are included in all models. Models in even numbered columns also contain linear state and demographic group specific time trends. Samples are calculated from complete CPS monthly files for years 1978 to 1999. All regressions are weighted by gender/age/education group's share of total population in each year. Adoption of legal doctrines is lagged by one year. 
Appendix Table 1:

Wrongful Discharge Laws by Region, State and Year

\begin{tabular}{|c|c|c|c|c|c|c|c|c|c|c|c|c|c|c|c|c|c|c|c|c|c|c|}
\hline & & & & & Key: & C & Implie & Contra & & $\mathbf{P}$ & Public & Policy & & $\mathbf{G}$ & Good F & aith & & & & & & \\
\hline & $\underline{1978}$ & $\underline{1979}$ & $\underline{1980}$ & $\underline{1981}$ & $\underline{1982}$ & $\underline{1983}$ & $\underline{1984}$ & $\underline{1985}$ & $\underline{1986}$ & $\underline{1987}$ & $\underline{1988}$ & $\underline{1989}$ & $\underline{1990}$ & $\underline{1991}$ & $\underline{1992}$ & $\underline{1993}$ & $\underline{1994}$ & $\underline{1995}$ & $\underline{1996}$ & $\underline{1997}$ & $\underline{1998}$ & $\underline{1999}$ \\
\hline \multicolumn{23}{|l|}{ New England } \\
\hline Connecticut & & & $P G$ & $P G$ & $P G$ & $P G$ & $P G$ & CPG & $C P G$ & $C P G$ & $C P G$ & $C P G$ & $C P G$ & $C P G$ & $C P G$ & $C P G$ & $C P G$ & $C P G$ & $C P G$ & $C P G$ & $C P G$ & $C P G$ \\
\hline Maine & $\mathrm{C}$ & $\mathrm{C}$ & $\mathrm{C}$ & $\mathrm{C}$ & C & $\mathrm{C}$ & $\mathrm{C}$ & $\mathrm{C}$ & C & $\mathrm{C}$ & $\mathrm{C}$ & C & C & $\mathrm{C}$ & $\mathrm{C}$ & $\mathrm{C}$ & C & $\mathrm{C}$ & $\mathrm{C}$ & $\mathrm{C}$ & $\mathrm{C}$ & C \\
\hline Massachusetts & $\mathrm{G}$ & $\mathrm{G}$ & $P G$ & $P G$ & $P G$ & $P G$ & $P G$ & $P G$ & $P G$ & $P G$ & CPG & $C P G$ & CPG & $C P G$ & $C P G$ & $C P G$ & $C P G$ & CPG & $C P G$ & $C P G$ & CPG & $C P G$ \\
\hline New Hampshire & $P G$ & $P G$ & $\mathrm{P}$ & $\mathrm{P}$ & $\mathrm{P}$ & $\mathrm{P}$ & $\mathrm{P}$ & $\mathrm{P}$ & $\mathrm{P}$ & $\mathrm{P}$ & $\mathrm{CP}$ & $\mathrm{CP}$ & $\mathrm{CP}$ & $\mathrm{CP}$ & $\mathrm{CP}$ & $C P$ & $\mathrm{CP}$ & $\mathrm{CP}$ & $\mathrm{CP}$ & $\mathrm{CP}$ & $C P$ & $\mathrm{CP}$ \\
\hline \multicolumn{23}{|l|}{ Rhode Island } \\
\hline Vermont & & & & & & & & $\mathrm{CP}$ & $\mathrm{CP}$ & $\mathrm{CP}$ & $\mathrm{CP}$ & $\mathrm{CP}$ & $\mathrm{CP}$ & $\mathrm{CP}$ & $\mathrm{CP}$ & $C P$ & $\mathrm{CP}$ & $C P$ & $\mathrm{CP}$ & $\mathrm{CP}$ & $C P$ & $\mathrm{CP}$ \\
\hline \multicolumn{23}{|l|}{ Middle Atlantic } \\
\hline New Jersey & & & $\mathrm{P}$ & $\mathrm{P}$ & $\mathrm{P}$ & $\mathrm{P}$ & $P$ & $C P$ & $\mathrm{CP}$ & $C P$ & $\mathrm{CP}$ & $\mathrm{CP}$ & $C P$ & $C P$ & $C P$ & $\mathrm{CP}$ & $C P$ & $C P$ & $C P$ & $C P$ & $C P$ & $C P$ \\
\hline New York & & & & & C & C & C & C & C & C & C & $\mathrm{C}$ & C & C & $\mathrm{C}$ & C & C & C & $\mathrm{C}$ & $\mathrm{C}$ & C & C \\
\hline Pennsylvania & $\mathrm{P}$ & $\mathrm{P}$ & $\mathrm{P}$ & $\mathrm{P}$ & $\mathrm{P}$ & $\mathrm{P}$ & $\mathrm{P}$ & $\mathrm{P}$ & $\mathrm{P}$ & $\mathrm{P}$ & $\mathrm{P}$ & $\mathrm{P}$ & $\mathrm{P}$ & $\mathrm{P}$ & $\mathrm{P}$ & $\mathrm{P}$ & $\mathrm{P}$ & $\mathrm{P}$ & $\mathrm{P}$ & $\mathrm{P}$ & $\mathrm{P}$ & $\mathrm{P}$ \\
\hline \multicolumn{23}{|l|}{ East North Central } \\
\hline Illinois & $C P$ & $C P$ & $C P$ & C P & $C P$ & $C P$ & $C P$ & $C P$ & $C P$ & $C P$ & $C P$ & $C P$ & $C P$ & $C P$ & $C P$ & $C P$ & $C P$ & $C P$ & $C P$ & $C P$ & $C P$ & $C P$ \\
\hline Indiana & $\mathrm{P}$ & $\mathrm{P}$ & $\mathrm{P}$ & $\mathrm{P}$ & $\mathrm{P}$ & $\mathrm{P}$ & $\mathrm{P}$ & $\mathrm{P}$ & $\mathrm{P}$ & $\mathrm{CP}$ & $\mathrm{CP}$ & $\mathrm{CP}$ & $C P$ & $\mathrm{CP}$ & $\mathrm{CP}$ & $C P$ & $\mathrm{CP}$ & $\mathrm{CP}$ & $\mathrm{CP}$ & $C P$ & $C P$ & $C P$ \\
\hline Michigan & $\mathrm{P}$ & $\mathrm{P}$ & $\mathrm{CP}$ & $\mathrm{CP}$ & $\mathrm{CP}$ & $\mathrm{CP}$ & $\mathrm{CP}$ & $\mathrm{CP}$ & $\mathrm{CP}$ & $\mathrm{CP}$ & $\mathrm{CP}$ & $\mathrm{CP}$ & $\mathrm{CP}$ & $\mathrm{CP}$ & $\mathrm{CP}$ & $\mathrm{CP}$ & $\mathrm{CP}$ & $\mathrm{CP}$ & $\mathrm{CP}$ & $\mathrm{CP}$ & $C P$ & $\mathrm{CP}$ \\
\hline Ohio & & & & & $\mathrm{C}$ & $\mathrm{C}$ & $\mathrm{C}$ & $\mathrm{C}$ & $\mathrm{C}$ & $\mathrm{C}$ & $\mathrm{C}$ & $\mathrm{C}$ & $C P$ & $C P$ & $C P$ & $\mathrm{CP}$ & $C P$ & $C P$ & $C P$ & $C P$ & $\mathrm{CP}$ & $C P$ \\
\hline Wisconsin & & & $\mathrm{P}$ & $\mathrm{P}$ & $\mathrm{P}$ & $\mathrm{P}$ & $\mathrm{P}$ & $\mathrm{CP}$ & $\mathrm{CP}$ & $C P$ & $\mathrm{CP}$ & $\mathrm{CP}$ & $\mathrm{CP}$ & CP & $\mathrm{CP}$ & $C P$ & $\mathrm{CP}$ & $\mathrm{CP}$ & $\mathrm{CP}$ & $\mathrm{CP}$ & $C P$ & $\mathrm{CP}$ \\
\hline \multicolumn{23}{|c|}{ West North Central } \\
\hline lowa & & & & & & & & $\mathrm{P}$ & $\mathrm{P}$ & $\mathrm{CP}$ & $\mathrm{CP}$ & $\mathrm{CP}$ & $\mathrm{CP}$ & $\mathrm{CP}$ & $\mathrm{CP}$ & $\mathrm{CP}$ & $\mathrm{CP}$ & $\mathrm{CP}$ & $\mathrm{CP}$ & $\mathrm{CP}$ & $\mathrm{CP}$ & $C P$ \\
\hline Kansas & & & & $\mathrm{P}$ & $\mathrm{P}$ & $P$ & $C P$ & $C P$ & $C P$ & $C P$ & $\mathrm{CP}$ & $\mathrm{CP}$ & $C P$ & $C P$ & $C P$ & $\mathrm{CP}$ & $C P$ & $C P$ & $C P$ & $C P$ & $\mathrm{CP}$ & $\mathrm{CP}$ \\
\hline Minnesota & & & & & & $\mathrm{C}$ & C & C & $\mathrm{CP}$ & $\mathrm{CP}$ & $\mathrm{CP}$ & $\mathrm{CP}$ & $\mathrm{CP}$ & $\mathrm{CP}$ & $\mathrm{CP}$ & $C P$ & $C P$ & $\mathrm{CP}$ & $\mathrm{CP}$ & $C P$ & $C P$ & $\mathrm{CP}$ \\
\hline Missouri & & & & & & C & $\mathrm{C}$ & $\mathrm{C}$ & $\mathrm{CP}$ & $\mathrm{CP}$ & $\mathrm{P}$ & $\mathrm{P}$ & $\mathrm{P}$ & $\mathrm{P}$ & $\mathrm{P}$ & $\mathrm{P}$ & $\mathrm{P}$ & $\mathrm{P}$ & $\mathrm{P}$ & $\mathrm{P}$ & $\mathrm{P}$ & $\mathrm{P}$ \\
\hline Nebraska & & & & & & $\mathrm{C}$ & C & C & $\mathrm{C}$ & $C P$ & $\mathrm{CP}$ & $\mathrm{CP}$ & $\mathrm{CP}$ & $\mathrm{CP}$ & $\mathrm{CP}$ & $\mathrm{CP}$ & $C P$ & $\mathrm{CP}$ & $\mathrm{CP}$ & $\mathrm{CP}$ & $C P$ & $\mathrm{CP}$ \\
\hline North Dakota & & & & & & & $\mathrm{C}$ & $\mathrm{C}$ & C & $\mathrm{CP}$ & $\mathrm{CP}$ & $\mathrm{CP}$ & $\mathrm{CP}$ & $\mathrm{CP}$ & $\mathrm{CP}$ & $\mathrm{CP}$ & $\mathrm{CP}$ & $\mathrm{CP}$ & $\mathrm{CP}$ & $\mathrm{CP}$ & $C P$ & $\mathrm{CP}$ \\
\hline South Dakota & & & & & & $\mathrm{C}$ & $\mathrm{C}$ & C & $\mathrm{C}$ & $\mathrm{C}$ & $C P$ & $\mathrm{CP}$ & $C P$ & $C P$ & $C P$ & $C P$ & $C P$ & $C P$ & $C P$ & $C P$ & $C P$ & $C P$ \\
\hline \multicolumn{23}{|l|}{ South Atlantic } \\
\hline Delaware & & & & & & & & & & & & & & & $P G$ & $P G$ & $P G$ & $P G$ & $P G$ & $P G$ & $P G$ & $P G$ \\
\hline \multicolumn{23}{|l|}{ Florida } \\
\hline \multicolumn{23}{|l|}{ Georgia } \\
\hline Maryland & & & & $\mathrm{P}$ & $\mathrm{P}$ & $\mathrm{P}$ & $\mathrm{P}$ & $C P$ & $\mathrm{CP}$ & $\mathrm{CP}$ & $\mathrm{CP}$ & $\mathrm{CP}$ & $C P$ & $\mathrm{CP}$ & $\mathrm{CP}$ & $\mathrm{CP}$ & $\mathrm{CP}$ & $C P$ & $\mathrm{CP}$ & $\mathrm{CP}$ & $C P$ & $\mathrm{CP}$ \\
\hline North Carolina & & & & & & & & $\mathrm{P}$ & $\mathrm{P}$ & $\mathrm{P}$ & $\mathrm{P}$ & $\mathrm{P}$ & $\mathrm{P}$ & $\mathrm{P}$ & $\mathrm{P}$ & $\mathrm{P}$ & $\mathrm{P}$ & $\mathrm{P}$ & $\mathrm{P}$ & $\mathrm{P}$ & $\mathrm{P}$ & $\mathrm{P}$ \\
\hline South Carolina & & & & & & & & $\mathrm{P}$ & $\mathrm{P}$ & $\mathrm{CP}$ & $\mathrm{CP}$ & $C P$ & $\mathrm{CP}$ & $\mathrm{CP}$ & $\mathrm{CP}$ & $C P$ & $\mathrm{CP}$ & $\mathrm{CP}$ & $\mathrm{CP}$ & $\mathrm{CP}$ & $C P$ & $\mathrm{CP}$ \\
\hline Virginia & & & & & & C & C & $C P$ & $C P$ & $C P$ & $C P$ & CP & $C P$ & $C P$ & $C P$ & CP & $C P$ & $C P$ & $C P$ & $C P$ & $C P$ & $C P$ \\
\hline West Virginia & $P$ & $P$ & $P$ & $P$ & $P$ & $P$ & $P$ & $\mathrm{P}$ & $C P$ & $C P$ & $C P$ & $C P$ & $C P$ & $C P$ & $C P$ & $C P$ & $C P$ & $C P$ & $C P$ & $C P$ & $C P$ & $C P$ \\
\hline
\end{tabular}


Appendix Table 1:

Wrongful Discharge Laws by Region, State and Year

\begin{tabular}{|c|c|c|c|c|c|c|c|c|c|c|c|c|c|c|c|c|c|c|c|c|c|c|}
\hline & \multirow[b]{2}{*}{$\underline{1978}$} & \multirow[b]{2}{*}{$\underline{1979}$} & \multirow[b]{2}{*}{$\underline{1980}$} & \multirow[b]{2}{*}{$\underline{1981}$} & \multirow{2}{*}{$\begin{array}{l}\text { Key: } \\
\underline{1982}\end{array}$} & \multirow{2}{*}{$\begin{array}{c}C \\
1983 \\
\end{array}$} & \multicolumn{3}{|c|}{ Implied Contract } & \multirow{2}{*}{$\begin{array}{c}P \\
1987 \\
\end{array}$} & \multicolumn{2}{|c|}{ Public Policy } & \multirow[b]{2}{*}{$\underline{1990}$} & \multirow{2}{*}{$\begin{array}{c}G \\
1991 \\
\end{array}$} & \multicolumn{2}{|c|}{ Good Faith } & \multirow[b]{2}{*}{$\underline{1994}$} & \multirow[b]{2}{*}{$\underline{1995}$} & \multirow[b]{2}{*}{$\underline{1996}$} & \multirow[b]{2}{*}{$\underline{1997}$} & \multirow[b]{2}{*}{$\underline{1998}$} & \multirow[b]{2}{*}{$\underline{1999}$} \\
\hline & & & & & & & $\underline{1984}$ & $\underline{1985}$ & $\underline{1986}$ & & $\underline{1988}$ & $\underline{1989}$ & & & 1992 & $\underline{1993}$ & & & & & & \\
\hline \multicolumn{23}{|c|}{ East South Central } \\
\hline Alabama & & & & & & & & & & $\mathrm{C}$ & $\mathrm{C}$ & C & $\mathrm{C}$ & C & $\mathrm{C}$ & $\mathrm{C}$ & $\mathrm{C}$ & $\mathrm{C}$ & C & $\mathrm{C}$ & $\mathrm{C}$ & $\mathrm{C}$ \\
\hline Kentucky & & & & & & $C P$ & CP & $C P$ & $C P$ & $C P$ & $C P$ & $C P$ & $C P$ & $C P$ & $C P$ & $C P$ & $C P$ & $C P$ & $C P$ & $C P$ & $C P$ & $C P$ \\
\hline Mississippi & & & & & & & & & & $\mathrm{P}$ & $\mathrm{P}$ & $\mathrm{P}$ & $\mathrm{P}$ & $\mathrm{P}$ & $\mathrm{P}$ & $\mathrm{CP}$ & $\mathrm{CP}$ & $\mathrm{CP}$ & $C P$ & $C P$ & $\mathrm{CP}$ & $C P$ \\
\hline Tennessee & & & & $\mathrm{C}$ & C & C & $\mathrm{CP}$ & $C P$ & $C P$ & $\mathrm{CP}$ & $\mathrm{CP}$ & $\mathrm{CP}$ & $\mathrm{CP}$ & $C P$ & $C P$ & $C P$ & $\mathrm{CP}$ & $\mathrm{CP}$ & $C P$ & $\mathrm{CP}$ & $\mathrm{CP}$ & $C P$ \\
\hline \multicolumn{23}{|c|}{ West South Central } \\
\hline Arkansas & & & $P$ & $\mathrm{P}$ & $\mathrm{P}$ & $C P$ & $C P$ & $\mathrm{CP}$ & $C P$ & $C P$ & $C P$ & $C P$ & $C P$ & $C P$ & $C P$ & $C P$ & $\mathrm{CP}$ & $\mathrm{CP}$ & $C P$ & $\mathrm{CP}$ & $\mathrm{CP}$ & $C P$ \\
\hline Louisiana & & & & & & & & & & & & & & & & & & & & & $\mathrm{G}$ & $\mathrm{G}$ \\
\hline Oklahoma & C & C & C & $\mathrm{C}$ & $\mathrm{C}$ & $C$ & C & $C G$ & $C G$ & $\mathrm{CG}$ & $C G$ & $C P$ & $C P$ & $C P$ & $C P$ & $C P$ & $C P$ & $C P$ & $C P$ & $C P$ & $C P$ & $C P$ \\
\hline Texas & & & & & & & $P$ & $C P$ & $C P$ & $C P$ & $C P$ & $C P$ & $C P$ & $C P$ & $C P$ & $C P$ & $C P$ & $C P$ & $C P$ & $C P$ & $C P$ & $C P$ \\
\hline
\end{tabular}

Mountain

\begin{tabular}{|c|c|c|c|c|c|c|c|c|c|c|c|c|c|c|c|c|c|c|c|c|c|c|}
\hline Arizona & & & & & & $\mathrm{C}$ & $\mathrm{C}$ & $C P G$ & $C P G$ & $C P G$ & $C P G$ & $C P G$ & $C P G$ & $C P G$ & $C P G$ & $C P G$ & $C P G$ & $C P G$ & $C P G$ & $C P G$ & $C P G$ & $C P G$ \\
\hline Colorado & & & & & & C & $\mathrm{C}$ & $\mathrm{CP}$ & $\mathrm{CP}$ & $\mathrm{CP}$ & $\mathrm{CP}$ & $\mathrm{CP}$ & $\mathrm{CP}$ & $\mathrm{CP}$ & $C P$ & $\mathrm{CP}$ & $\mathrm{CP}$ & $\mathrm{CP}$ & $\mathrm{CP}$ & $C P$ & $\mathrm{CP}$ & $\mathrm{CP}$ \\
\hline Idaho & $\mathrm{CP}$ & $\mathrm{CP}$ & $\mathrm{CP}$ & $C P$ & $\mathrm{CP}$ & $\mathrm{CP}$ & $\mathrm{CP}$ & $\mathrm{CP}$ & $\mathrm{CP}$ & $C P$ & $C P$ & $C P G$ & $C P G$ & $C P G$ & $C P G$ & CPG & $C P G$ & $C P G$ & $C P G$ & $C P G$ & $C P G$ & $C P G$ \\
\hline Montana & & & $\mathrm{P}$ & $\mathrm{P}$ & $P G$ & $P G$ & $P G$ & $P G$ & $P G$ & $C P G$ & CPG & $C P G$ & $C P G$ & $C P G$ & $C P G$ & $C P G$ & $C P G$ & $C P G$ & $C P G$ & $C P G$ & $C P G$ & $C P G$ \\
\hline Nevada & & & & & & $C$ & $C P$ & $C P$ & $C P$ & $C P G$ & $C P G$ & $C P G$ & $C P G$ & $C P G$ & $C P G$ & $C P G$ & $C P G$ & $C P G$ & $C P G$ & $C P G$ & $C P G$ & $C P G$ \\
\hline New Mexico & & & $\mathrm{C}$ & C & C & $C P$ & $C P$ & $C P$ & $C P$ & $C P$ & $C P$ & $C P$ & $\mathrm{CP}$ & $C P$ & $C P$ & $C P$ & $C P$ & $C P$ & $C P$ & $C P$ & $C P$ & $C P$ \\
\hline Utah & & & & & & & & & C & C & C & $\mathrm{CP}$ & $C P$ & $\mathrm{CP}$ & $\mathrm{CP}$ & $\mathrm{CP}$ & $C P$ & $C P$ & $\mathrm{CP}$ & $C P$ & $\mathrm{CP}$ & $\mathrm{CP}$ \\
\hline Wyoming & & & & & & & & $\mathrm{C}$ & C & C & C & $C P$ & $C P$ & $C P$ & $C P$ & $C P$ & $C P G$ & $C P G$ & $C P G$ & $C P G$ & $C P G$ & $C P G$ \\
\hline \multicolumn{23}{|l|}{ Pacific } \\
\hline Alaska & & & & & & $C G$ & $C G$ & $C G$ & $C G$ & $C G$ & $C G$ & $C P G$ & $C P G$ & $C P G$ & $C P G$ & $C P G$ & $C P G$ & $C P G$ & $C P G$ & $C P G$ & $C P G$ & $C P G$ \\
\hline California & $\mathrm{CP}$ & $\mathrm{CP}$ & $C P G$ & C P G & C P G & $C P G$ & $C P G$ & C P G & $C P G$ & C P G & C P G & $C P G$ & $C P G$ & $C P G$ & $C P G$ & C P G & $C P G$ & C P G & $C P G$ & $C P G$ & $C P G$ & $C P G$ \\
\hline Hawaii & & & & & $\mathrm{P}$ & $\mathrm{P}$ & $\mathrm{P}$ & $\mathrm{P}$ & $C P$ & $C P$ & $C P$ & $C P$ & $C P$ & $C P$ & $C P$ & $C P$ & $C P$ & $C P$ & $C P$ & $C P$ & $C P$ & $C P$ \\
\hline Oregon & $C P$ & $C P$ & $C P$ & $C P$ & $C P$ & $C P$ & $C P$ & $C P$ & $C P$ & $C P$ & $C P$ & $C P$ & $C P$ & $C P$ & $C P$ & $C P$ & $C P$ & $C P$ & $C P$ & $C P$ & $C P$ & $C P$ \\
\hline Washington & C & C & C & C & C & C & C P & C P & C P & C P & $C P$ & C P & $C P$ & C P & $C P$ & $C P$ & $C P$ & $C P$ & $C P$ & $C P$ & $C P$ & CP \\
\hline
\end{tabular}

Source: Authors' analysis of case law. 


\section{Appendix Table 2:}

Unweighted Difference-in-Difference Estimates of the Impact of Wrongful Discharge Laws on Employment and Earnings for Years 1978 - 1999: Contrasting Outcomes in Years Two and Three Following Adoption of Doctrine to Years One and Two Prior to Adoption

\begin{tabular}{|c|c|c|c|c|c|c|c|c|}
\hline & \multicolumn{4}{|c|}{ A. $100 \mathrm{X}$ Employment Measure } & \multicolumn{4}{|c|}{ B. $100 \times$ Log Earnings Measure } \\
\hline & \multicolumn{2}{|c|}{$\underline{\ln (\mathrm{Emp} / \mathrm{Pop})}$} & \multicolumn{2}{|c|}{ Emp/Pop } & \multicolumn{2}{|c|}{ Median FT Weekly } & \multicolumn{2}{|c|}{ Median Hourly } \\
\hline & $(1)$ & $(2)$ & (3) & (4) & (1) & (2) & (3) & (4) \\
\hline Implied Contract & $\begin{array}{l}-1.34 \\
(0.38)\end{array}$ & $\begin{array}{l}-0.80 \\
(0.29)\end{array}$ & $\begin{array}{l}-0.82 \\
(0.27)\end{array}$ & $\begin{array}{l}-0.43 \\
(0.18)\end{array}$ & $\begin{array}{c}0.46 \\
(0.50)\end{array}$ & $\begin{array}{c}0.03 \\
(0.75)\end{array}$ & $\begin{array}{c}0.03 \\
(0.87)\end{array}$ & $\begin{array}{c}0.59 \\
(0.59)\end{array}$ \\
\hline$R^{2}$ & 0.889 & 0.893 & 0.901 & 0.905 & 0.825 & 0.820 & 0.817 & 0.824 \\
\hline $\mathrm{n}$ & \multicolumn{4}{|c|}{52,224} & \multicolumn{2}{|c|}{48,424} & \multicolumn{2}{|c|}{49,192} \\
\hline Public Policy & $\begin{array}{l}-0.29 \\
(0.40)\end{array}$ & $\begin{array}{l}-0.60 \\
(0.29)\end{array}$ & $\begin{array}{l}-0.16 \\
(0.27)\end{array}$ & $\begin{array}{l}-0.38 \\
(0.19)\end{array}$ & $\begin{array}{l}-0.60 \\
(0.54)\end{array}$ & $\begin{array}{c}0.20 \\
(0.44)\end{array}$ & $\begin{array}{l}-0.69 \\
(0.60)\end{array}$ & $\begin{array}{l}-0.16 \\
(0.51)\end{array}$ \\
\hline$R^{2}$ & 0.887 & 0.891 & 0.898 & 0.902 & 0.815 & 0.821 & 0.813 & 0.819 \\
\hline $\mathrm{n}$ & \multicolumn{4}{|c|}{55,488} & \multicolumn{2}{|c|}{51,264} & \multicolumn{2}{|c|}{52,140} \\
\hline Good Faith & $\begin{array}{l}-0.88 \\
(0.48)\end{array}$ & $\begin{array}{l}-0.80 \\
(0.65)\end{array}$ & $\begin{array}{l}-0.58 \\
(0.36)\end{array}$ & $\begin{array}{l}-0.51 \\
(0.44)\end{array}$ & $\begin{array}{c}0.04 \\
(1.02)\end{array}$ & $\begin{array}{c}1.43 \\
(0.89)\end{array}$ & $\begin{array}{c}0.17 \\
(1.20)\end{array}$ & $\begin{array}{c}1.97 \\
(0.91)\end{array}$ \\
\hline$R^{2}$ & 0.882 & 0.886 & 0.892 & 0.897 & 0.809 & 0.815 & 0.810 & 0.817 \\
\hline $\mathrm{n}$ & \multicolumn{4}{|c|}{55,296} & \multicolumn{2}{|c|}{48,296} & \multicolumn{2}{|c|}{49,088} \\
\hline Region $x$ year dummies & No & Yes & No & Yes & No & Yes & No & Yes \\
\hline
\end{tabular}

Huber-White robust standard errors in parentheses allow for unrestricted error correlation within states.

Dependent variables, samples, and specificiations are identical to Table 1. Weighting differs. Each state-year. month observation is given equal weight, with the 8 demographic cells within each state weighted proportionate to their share of state population. 